\title{
Soil microbial nitrogen-transforming genes influenced by tree species and fertilization in an Appalachian hardwood forest
}

\author{
Emma G. Fox-Fogle \\ ef0051@mix.wvu.edu
}

Follow this and additional works at: https://researchrepository.wvu.edu/etd

Part of the Forest Biology Commons

\author{
Recommended Citation \\ Fox-Fogle, Emma G., "Soil microbial nitrogen-transforming genes influenced by tree species and \\ fertilization in an Appalachian hardwood forest" (2021). Graduate Theses, Dissertations, and Problem \\ Reports. 8278. \\ https://researchrepository.wvu.edu/etd/8278
}

This Thesis is protected by copyright and/or related rights. It has been brought to you by the The Research Repository @ WVU with permission from the rights-holder(s). You are free to use this Thesis in any way that is permitted by the copyright and related rights legislation that applies to your use. For other uses you must obtain permission from the rights-holder(s) directly, unless additional rights are indicated by a Creative Commons license in the record and/ or on the work itself. This Thesis has been accepted for inclusion in WVU Graduate Theses, Dissertations, and Problem Reports collection by an authorized administrator of The Research Repository @ WVU. For more information, please contact researchrepository@mail.wvu.edu. 


\title{
Soil microbial nitrogen-transforming genes influenced by tree species and fertilization in an Appalachian hardwood forest
}

\author{
Emma Genevera Fox-Fogle \\ Thesis submitted \\ to the Eberly College of Arts and Science \\ at West Virginia University \\ In partial fulfillment of the requirements for the degree of \\ Master of Science in \\ Biology \\ Timothy Driscoll, Ph.D., Co-Chair \\ Charlene Kelly, Ph.D., Co-Chair \\ Mary Beth Adams, Ph.D. \\ Zachary Freedman, Ph.D. \\ Edward Brzostek, Ph.D. \\ Department of Biology
}

Morgantown, West Virginia

2021

Keywords: Nitrogen, Fernow Experimental Forest, Acidification, Denitrification, Nitrification, Functional genes,

Copyright 2021 Emma Genevera Fox-Fogle 


\title{
Abstract \\ Soil microbial nitrogen-transforming genes influenced by tree species and fertilization in an Appalachian hardwood forest
}

\author{
Emma Genevera Fox-Fogle
}

Many forest ecosystems have been receiving elevated nitrogen $(\mathrm{N})$ deposition due to human activity. Increased ecosystem $\mathrm{N}$ threatens soil fertility, water and air quality, and modifies the soil microbially-mediated $\mathrm{N}$ cycle in complex ways. The current study investigates how the abundance of key functional $\mathrm{N}$ cycling genes within soil bacteria is altered by $\mathrm{N}$ deposition and further mediated by different dominant tree species at the Fernow Experimental Forest, WV. Soils were analyzed from two watersheds, where watershed 3 (WS 3) has been receiving experimental applications of $\mathrm{N}$ fertilizer that are $2 \mathrm{x}$ historic ambient $\mathrm{N}$ deposition and $5 \mathrm{x}$ the current ambient $\mathrm{N}$ deposition, relative to a reference watershed (WS 7). Abundance of four $\mathrm{N}$ cycling functional genes responsible for nitrate $\left(\mathrm{NO}_{3}{ }^{-}\right)$and nitrous oxide $\left(\mathrm{N}_{2} \mathrm{O}\right)$ production (amoA, nirK, nirS, nosZ) were targeted for quantification using qPCR. We hypothesized that the abundance of these $\mathrm{N}$ cycling functional genes would be significantly different in soils influenced by elevated $\mathrm{N}$ deposition. It was expected that the abundance of genes would reflect the production of $\mathrm{NO}_{3}{ }^{-}$and $\mathrm{N}_{2} \mathrm{O}$ from soils, measured as soil nitrate content and potential denitrification production from soil samples from beneath four individual tree species (tulip poplar, sweet birch, black cherry, and northern red oak). These tree species represent two mycorrhizal fungal associations (arbuscular and ectomycorrhizal); thus, we also tested whether functional gene abundance can be predicted by mycorrhizal association. It was expected that nitrification would be greatest in WS 3 and beneath arbuscular mycorrhizal trees because AM-associated trees sometimes have relatively more rapid litter decomposition leading to greater $\mathrm{N}$ losses than ECM associated tree species. Greater $\mathrm{N}_{2} \mathrm{O}$ production was also expected in WS 3 due to the acidified soil altering the microbial capacity to reduce $\mathrm{N}_{2} \mathrm{O}$ to $\mathrm{N}_{2}$ gas. Soil beneath black cherry, an AM-associated species, contained significantly more $\mathrm{NH}_{4}{ }^{+}$within WS 3. Fertilization has altered gene abundance in WS 3, leading to reduced nirK and nos $Z$ abundance. Tree species did not influence gene abundance in either watershed, although AM-associated trees demonstrated reduced nirK abundance in WS 3. Soil beneath black cherry trees had reduced nirK and nos $Z$ abundance as well as altered nitrification of $\mathrm{NH}_{4}{ }^{+}$in WS 3, indicating that soils beneath black cherry trees may have altered $\mathrm{N}$ processing under fertilization. The reduction of functional gene abundance was not correlated with $\mathrm{N}$ transforming processes in either watershed. Gene abundance is not a strong predictor of $\mathrm{N}$ transforming rates in this study. Future research of the microbial community, paired with enzymatic activity, will enable better understanding of relationships between structure and function of the microbial community on $\mathrm{N}$ cycling processes. 


\section{Acknowledgements}

First off, I must thank Elizabeth Matejckyz for being not only an incredible lab mate but also my best friend. None of this would have been possible without her help in the field and in the lab. I would also like to thank Dr. Tim Driscoll and Dr. Charlene Kelly for this opportunity to pursue graduate studies at West Virginia University. I thank my committee members Zachary Freedman, Mary Beth Adams, and Eddie Brzostek for helping develop my study.

Special thanks to my family for their support and guidance through the process. 


\section{Table of Contents}

Introduction and Background

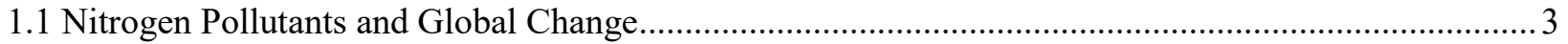

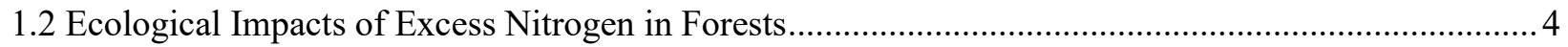

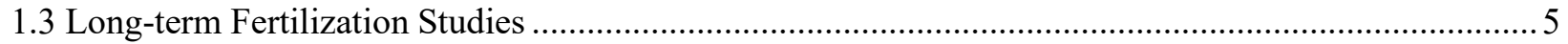

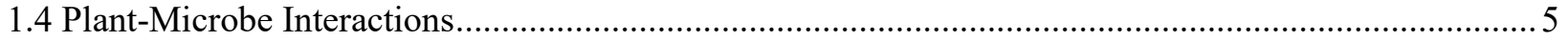

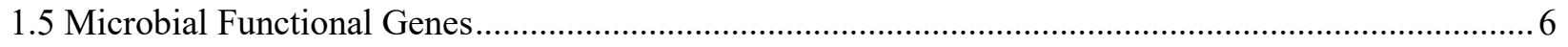

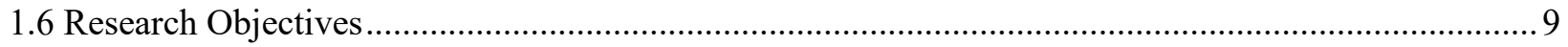

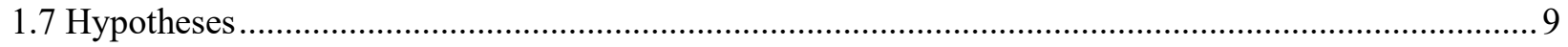

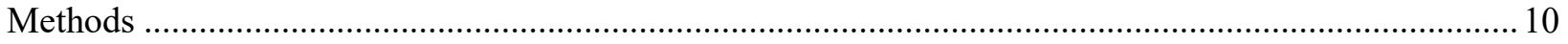

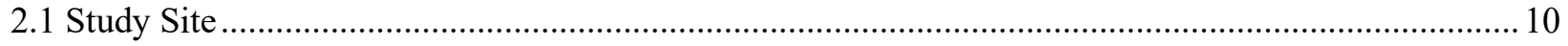

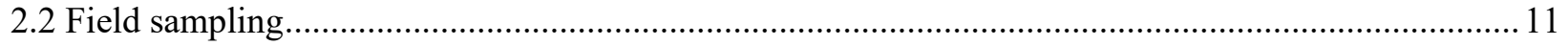

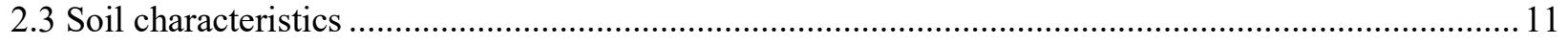

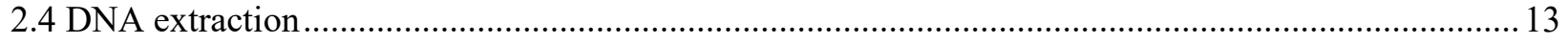

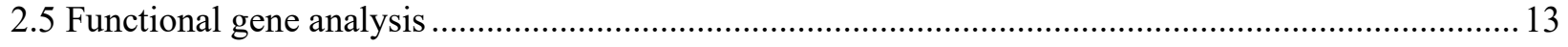

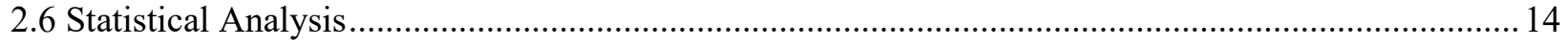

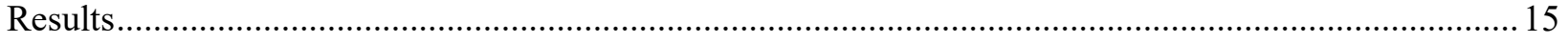

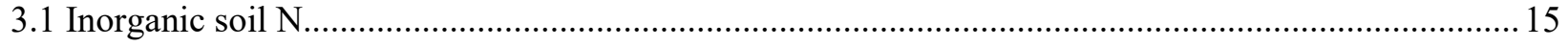

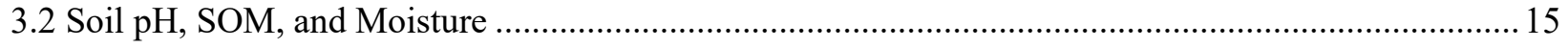

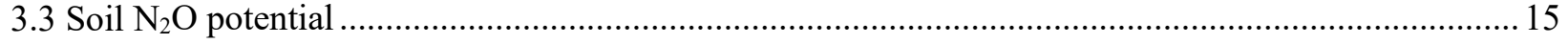

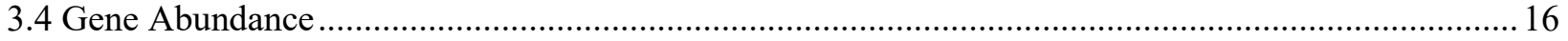

3.5 Relationships of Environmental Variable to Gene Abundance ….................................................... 16

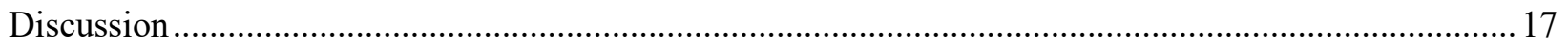

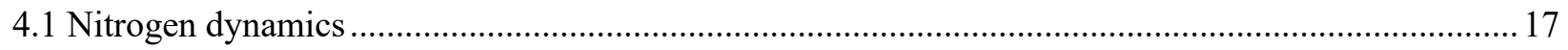

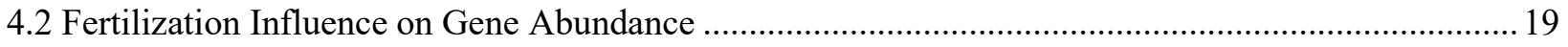

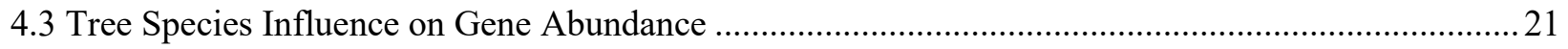

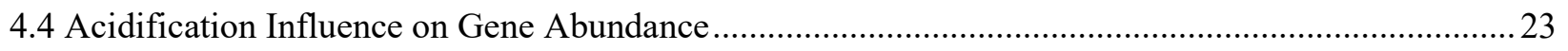

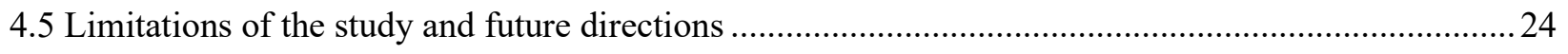

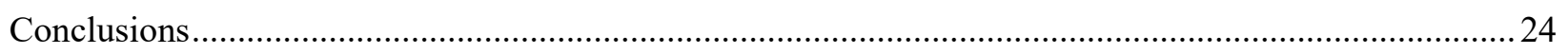

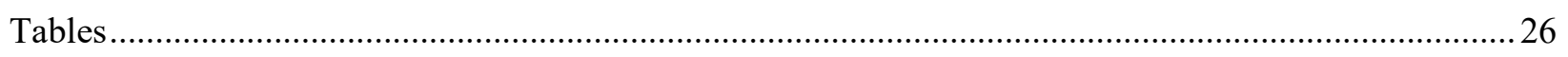

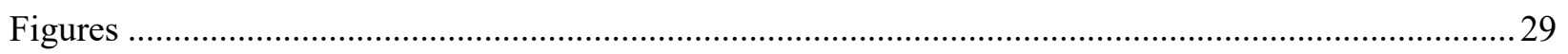

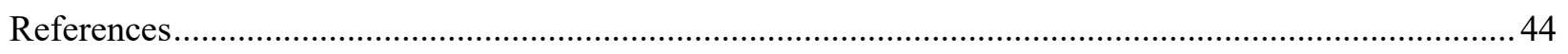

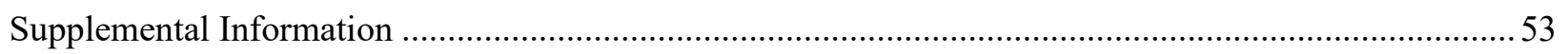




\section{Introduction and Background}

The soil microbiome is pivotal in the processes of nitrogen $(\mathrm{N})$ cycling, as microbial-mediated transformations regulate biologically available $\mathrm{N}$ and emissions of atmospheric $\mathrm{N}$ (via $\mathrm{N}$ fixation, ammonification, nitrification, and denitrification). The global atmosphere is composed of $78 \%$ dinitrogen $\left(\mathrm{N}_{2}\right)$ gas, which is inaccessible to a majority of organisms due to the triple bond between the $\mathrm{N}$ atoms. $\mathrm{N}$ is historically the most common limiting nutrient for forest vegetation in the northern hemisphere (Vitousek, et al. 1997) and is essential for functioning ecosystems. However, up until the 1990s, areas in the northeastern U.S. had been receiving high amounts of $\mathrm{N}$ due to anthropogenic activities such as the burning of fossil fuels and agricultural fertilization (Driscoll, et al. 2001; Schwede \& Lear, 2014). These activities increased global rates of N deposition to terrestrial ecosystems, which has been cited as a factor in a series of plant and soil responses (Thoms, et al. 2012; Gilliam, et al. 2016) such as; increased above ground biomass (Vitousek, et al. 1997), decreased root biomass (Nadelhoffer, 2000), increased nitrate $\left(\mathrm{NO}_{3}{ }^{-}\right)$leaching, and increased nitrous oxide $\left(\mathrm{N}_{2} \mathrm{O}\right)$ emissions from soil (Aber et al., 1998) $\mathrm{N}$ deposition peaked in the northeastern U.S. at $15 \mathrm{~kg} \mathrm{~N} \mathrm{ha}^{-1} \mathrm{yr}^{-1}$ in 1979 , et al. 2021). The burning of fossil fuels releases greenhouse gases such as $\mathrm{N}_{2} \mathrm{O}$, nitrogen dioxide $\left(\mathrm{NO}_{2}\right)$, sulfur dioxide $\left(\mathrm{SO}_{2}\right)$, and sulfate $\left(\mathrm{SO}_{4}\right)$. West Virginia, USA has historically received high amounts of wet deposition $\mathrm{N}$ and sulfur (S) in the form of acid deposition, due the proximity of the coal burning powerplants of the Ohio River valley (Burnham, et al. 2017).

Acid deposition is the formation of sulfuric $\left(\mathrm{H}_{2} \mathrm{SO}_{4}\right)$ and nitric $\left(\mathrm{HNO}_{3}\right)$ acids via $\mathrm{SO}_{\mathrm{x}}$ and $\mathrm{NO}_{\mathrm{x}}$ compounds emitted from the burning of fossil fuels. It was first reported to be an ecological issue in the 1960s (Grennfelt, et al. 2020), and is known to have impacts on forest health and productivity (DeHayes, et al. 1999). Forest health in the northeastern U.S. began declining in the late 1900s as calcium $\left(\mathrm{Ca}^{2+}\right)$ and other essential nutrients leached from the soil to water bodies such as streams, rivers, lakes, and the oceans (Adams, DeWalle, \& Hom, 2006). These waterbodies also experienced intense acidification causing aquatic life to decline (Grennfelt, et al. 2020) and leading to federal regulations such as the Clean Air Act (EPA). Since the enactment of the Clean Air Act in 1970, and subsequent amendments in 1977 and 1990, the deposition of reactive $\mathrm{N}$ has decreased significantly in the eastern U.S. (Burns, et al. 2021; Mathias \& Thomas, 2018). The 1990 
amendments introduced regulatory programs for acid rain control, and while some recovery of impacted forests has occurred due to decreased emissions, it is a long-term process (Mathias \& Thomas, 2018). A 2015 study indicated recovery in the form of decreasing plant available aluminum $\left(\mathrm{Al}^{3+}\right)$ and increasing soil $\mathrm{pH}$ in 13 of 27 forested sites across the northeastern U.S. and southeastern Canada (Lawrence, et al. 2015). $\mathrm{NO}_{\mathrm{x}}$ emissions have decreased since the early 2000s due to the federal and state regulations put in place for $\mathrm{NO}_{\mathrm{x}}$ emissions (Schwede \& Lear, 2014) and $\mathrm{SO}_{\mathrm{x}}$ emissions in the United States have decreased significantly over the three decades due to emission control policies (Aas, et al. 2019). However, atmospheric acid deposition is only one way by which ecosystems can receive excess amounts of $\mathrm{N}$.

As biologically available $\mathrm{N}$ limited agricultural production in the $19^{\text {th }}$ century, the industrial conversion process known as the Haber-Bosch process was engineered in the early 1900s. The use of the Haber-Bosch process has allowed high-yield agriculture to flourish, consequently introducing large amounts of reactive $\mathrm{N}$ into systems through the large-scale and widespread application of inorganic $\mathrm{N}$ fertilizers to agricultural land (Schlesinger \& Bernhardt, 2013). Use of the Haber-Bosch process produces approximately 150 million tons of ammonia $\left(\mathrm{NH}_{3}\right)$ for fertilizer worldwide, through the pressurization of $\mathrm{N}_{2}$ and $\mathrm{H}_{2}$ gas (Kyriakou, et al. 2020). Atmospheric $\mathrm{NH}_{3}$ deposition increased from the 1960's into the mid-2010s, from $33.1 \mathrm{Gg} \mathrm{N}$ year ${ }^{-1}$ to $566.5 \mathrm{Gg} \mathrm{N}$ year $^{-1}$ (Xu, et al. 2018), largely due to agricultural fertilization and livestock production (Schwede \& Lear, 2014). While $\mathrm{NH}_{3}$ is not the focus if this study, it is a contributor to increased bioavailable environmental $\mathrm{N}$.

Fertilization has improved our ability to produce food for a growing population. Unfortunately, excess $\mathrm{N}$ fertilization has created large-scale ecological impacts, including water quality issues related to the leaching of nitrate $\left(\mathrm{NO}_{3}{ }^{-}\right)$(Singh \& Sekhon ,1979) and the volatilization of $\mathrm{NH}_{3}$ and gaseous by-products of microbial conversion (particularly $\mathrm{NO}$ and $\mathrm{N}_{2} \mathrm{O}$ ), both of which can also harm air quality. $\mathrm{NH}_{4}{ }^{+}$volatilization occurs when $\mathrm{NH}_{4}{ }^{+}$is converted to $\mathrm{NH}_{3}$ gas which is then released to the atmosphere, and largely occurs in moist, near neutral agricultural soils (Hamid \& Mahler, 1994). $\mathrm{NO}$ and $\mathrm{NO}_{2}$ are main contributors to smog and associated human health problems (EPA 2016). While industrial sources are a major contributor to $\mathrm{NO}_{2}$ emissions (EPA 2016), fertilized soils also have a large potential for production of $\mathrm{NO}_{2}(\mathrm{Oikawa}$, et al. 2015). Agricultural soils are also the major contributor to $\mathrm{N}_{2} \mathrm{O}$ sources. as the need for higher crop yields increases 
$\mathrm{N}_{2} \mathrm{O}$ and $\mathrm{NO}_{2}$ emissions are predicted to follow suit (Reay, et al. 2012). Elevated $\mathrm{N}$ deposition has contributed to altered biogeochemical cycling in many ecosystems, as $\mathrm{N}$ input affects the rates of microbially-driven $\mathrm{N}$ cycling processes such as nitrification and denitrification (Treseder, 2008; Wallenstein, et al. 2006).

\subsection{Nitrogen Pollutants and Global Change}

In order to mitigate the impact of increased $\mathrm{N}$ in ecosystems, it is necessary to understand the ecosystem properties that influence $\mathrm{N}$ transformations and resultant $\mathrm{N}$ products (Backman \& Klemedtsson 2003; Hallin, et al. 2009; Kelly, et al. 2021). The N cycle is a complex biogeochemical cycle including biotic uptake, ammonification, nitrification, denitrification, and $\mathrm{N}$ fixation (Figure 1). Nitrogen compounds are common outputs from soils. One such pollutant, $\mathrm{N}_{2} \mathrm{O}$, is a gaseous form of $\mathrm{N}$ emitted by agricultural and anerobic soils due to fertilization and oxygen depletion (Aamar, et al. 2020) via microbial denitrification and nitrification, with nitrification being the common pathway. $\mathrm{N}_{2} \mathrm{O}$ is a major greenhouse gas and the dominant ozone-depleting substance produced by human activity (Ravishankara, et al. 2009), and soil is the main source of atmospheric $\mathrm{N}_{2} \mathrm{O}$, representing $56-70 \%$ of all global sources (Butterbach-Bahl, et al. 2013). Emissions of $\mathrm{N}_{2} \mathrm{O}$ are particularly high in areas where $\mathrm{N}$ is available in excess, such as agricultural systems and areas of high $\mathrm{N}$ deposition such as the northeastern U.S. (Firestone \& Davidson, 1989; Davidson \& Verchot, 2000). However, current estimates of $\mathrm{N}_{2} \mathrm{O}$ emissions from temperate forests vary significantly. Several European temperate forests report high annual $\mathrm{N}_{2} \mathrm{O}$ emissions (Eickenscheidt, 2011; Eickenscheidt \& Brumme, 2013). On the contrary, low $\mathrm{N}_{2} \mathrm{O}$ emissions have been reported from eastern U.S. forests (Castro, et al. 1992; Peterjohn, et al. 1996). While $\mathrm{N}_{2} \mathrm{O}$ accounts for only an estimated $10 \%$ of total greenhouse gas emissions, it has a 300 -fold greater impact on global warming processes than carbon dioxide $\left(\mathrm{CO}_{2}\right)$ (Bates et al. 2008; Richardson et al. 2009). $\mathrm{N}_{2} \mathrm{O}$ production in soil depends upon soil conditions, such as moisture, temperature, oxygen availability, available organic carbon and $\mathrm{N}$, and $\mathrm{C}: \mathrm{N}$ ratio of vegetative litter (Davidson, 1993; Pilegaard, 2013).

Another potential pollutant produced in the $\mathrm{N}$ cycle is $\mathrm{NO}_{3}{ }^{-}$, which is formed via the oxidative microbial process of nitrification. It is a soluble, highly mobile anion repelled by soil surface negative charges, which are dominant in strongly weathered soil such as in the eastern U.S. Consequently, $\mathrm{NO}_{3}{ }^{-}$is prone to leaching from soil when water percolates through the soil profile 
removing minerals causing acidification and downstream nutrient loading in water (Fenn, et al. 1998; Schlesinger \& Bernhardt, 2013) and resulting in soil nutrient depletion (Aber, et al. 1995), soil acidification (Aber, et al. 1989), and water quality issues. Nutrient loading, due to excess N, may result in harmful water quality impacts, such as harmful algal blooms and eutrophication. Eutrophication occurs when nutrient loading of $\mathrm{NO}_{3}{ }^{-}$and phosphorus $(\mathrm{P})$ increase the growth and biomass of algae. As the algae die and decomposes, the dissolved oxygen content in the aquatic system is depleted, potentially leading to fish kills and cyanobacteria blooms. Eutrophication is one of the most widespread water quality issues affecting river, streams, and lakes, leading to economic costs of approximately $\$ 2.2$ billion in U.S. freshwater systems alone (Smith, Tilman, \& Nekola, 1999; Dodds, et al. 2009).

\subsection{Ecological Impacts of Excess Nitrogen in Forests}

The effects of excess $\mathrm{N}$ include eutrophication (discussed above), soil and water acidification, and shifts in species composition and biodiversity (Tsiknia, et al. 2015). Short term fertilization causes an increase in biomass and forest productivity due to alleviation of $\mathrm{N}$ limitations; however, when biological uptake capacity is reached productivity decline can ensue (Vitousek, et al. 1997). Longterm fertilization is associated with negative impacts due to exceeding the ecosystem $\mathrm{N}$ requirements (Aber, et al. 1989; Fenn, et al. 1998). Chronic $\mathrm{N}$ inputs from anthropogenic activities can lead to $\mathrm{N}$ levels in excess of biological demand, leading to what is commonly known as $\mathrm{N}$ saturation (Aber, et al. 1989; Fenn, et al. 1998; Lovett \& Goodale, 2011). The N saturation theory as described by Aber et al. (1989), characterized the later-stage effects as forest decline, including $\mathrm{NO}_{3}{ }^{-}$leaching with associated base cation depletion, soil acidification, and increased nitrous oxide $\mathrm{N}_{2} \mathrm{O}$ emissions. Forest decline due to $\mathrm{N}$ saturation is defined by visible tree death, the reduction of fine root biomass, reduction in mycorrhizal fungi, and reduction of bacterial biomass (Aber, et al. 1989; Fenn, et al. 1998; Treseder, 2008). Revised N saturation hypotheses indicate more of a continuum than distinct stages as ecosystems have differing starting points and $\mathrm{N}$ limitations (Aber, 1998; Lovett \& Goodale, 2011). The reduction of fine root biomass is caused by a higher rate of fine root turnover and lesser nutrient allocation to production of fine roots (Nadelhoffer, 2000). Chronic $\mathrm{N}$ deposition can shift the associated soil microbial community structure, fungal abundance, and organic matter chemistry in forests (Wallenstein, et al. 2006; Frey, et al. 2014). Shifts in microbial community structure can influence the processes of nitrification and 
denitrification (Petersen, et al. 2012), which in turn can further impact the production of $\mathrm{N}$ pollutants such as $\mathrm{N}_{2} \mathrm{O}$ and $\mathrm{NO}_{3}{ }^{-}$. Symbiotic mycorrhizal fungi colonization of plant roots, both ectomycorrhizal (ECM) and arbuscular mycorrhizal (AM) fungi, may also decline with increased $\mathrm{N}$, due to reduced carbon (C) allocation as $\mathrm{N}$ is no longer limiting for the host plant (Treseder, 2004; Hogberg, et al. 2010; Burnham, et al. 2017).

Soil acidification resulting from elevated $\mathrm{NH}_{4}{ }^{+}$deposition can occur due to a buildup of hydrogen $\left(\mathrm{H}^{+}\right)$cations, causing soil $\mathrm{pH}$ to decrease. Increases in $\mathrm{H}^{+}$occur when plants uptake $\mathrm{N}$ in the form of $\mathrm{NH}_{4}^{+}$, a process that leaves $\mathrm{H}^{+}$in the soil and leads to acidification (Schlesinger \& Bernhardt, 2013), as well as through the oxidation process of nitrification. Large additions of $\mathrm{NH}_{4}{ }^{+}$-based fertilizers can displace base cations that buffer the soil against acidification, causing them to leach out of the soil (Driscoll, et al. 2001). Soil acidification leads to changes in soil chemistry and microbial community composition and can impact vegetation. The loss of base cations such as $\mathrm{Ca}^{2+}$ and $\mathrm{Mg}^{2+}$ can cause nutrient limitations for vegetation leading to species composition shifts (Kogelman \& Sharpe, 2006; Elias, Burger, \& Adams 2009). In severe cases of soil acidification, aluminum $\left(\mathrm{Al}^{3+}\right)$ buffering can occur when there is minimal $\mathrm{Ca}^{2+}$ and $\mathrm{Mg}^{2+}$ left in the soil, causing vegetation damage (Schlesinger \& Bernhardt, 2013).

\subsection{Long-term Fertilization Studies}

Long-term fertilization studies have provided large data sets on forest vegetation and soil response to increased N. Several long-term N fertilization experiments have focused on the response to chronic $\mathrm{N}$ additions over the course of decades - the USDA Forest Service Fernow Experimental Forest (FEF) (Adams, DeWalle \& Hom, 2006) and the University of Maine Bear Brook Watersheds have paired watershed experiments that have been ongoing since 1989, although both are now in recovery phases of the study as fertilization has ceased after 30 years of fertilization (Venterea, et al. 2004). The long-term fertilization studies allow researchers to study the effects of

N fertilization (Peterjohn, Adams \& Gilliam 1996; Gilliam, et al. 2016; Gilliam, Adams and Peterjohn, 2020), and have documented ecosystem responses of decreased vegetative species diversity (Chapin III, et al. 2000) and shifts in the microbial community (Carrara, et al. 2018).

\subsection{Plant-Microbe Interactions}


Mutualistic plant-microbe interactions contribute directly to essential ecosystem processes. The soil microbial community plays an essential part in the processing and storage of $\mathrm{N}$ and is influenced by the dominant vegetation, due to differences in the chemical and physical make-up of the plant litter, as well as root physiology and mycorrhizal association (both AM or ECM fungi). Many studies have documented vegetation-mediated variation in N-cycling process rates (Melillo et al. 1982; Peterjohn et al. 2015; Ribbons et al. 2016). However, the influence of tree species on the soil microbial community may be altered by atmospheric deposition of $\mathrm{N}$, or in areas receiving high amounts of $\mathrm{N}$ fertilizer (Treseder, 2008). Changes in dominant above-ground vegetation composition impact the associated soil microbiome in function, storage, and processing rates of $\mathrm{N}$ (Grayston \& Prescott, 2005; Ribbons, et al. 2016).

The soil microbial community is influenced by tree species composition directly due to differences in leaf litter composition (Thoms, et al. 2012), as litter provides the initial nutrient content for decomposers and root exudates, and indirectly through fungal association (Phillips, Brzostek \& Midgley 2013). Multiple studies (Chapman, et al. 2005; Phillips, Brzostek, \& Midgley, 2013) have linked fungal association such as AM or ECM to a variety of feedback loops in nutrient cycling. AM-associated tree species are correlated with more rapid litter decomposition relative to ECMassociated species, due to a generally lower C:N ratio of the litter (Midgley \& Phillips 2014) Additionally, ECM fungi have higher enzymatic capability for mining nutrients compared to AM fungi (Lucas \& Casper, 2007), which allows the fungi to break down recalcitrant litter that is commonly associated with ECM species such as oaks, conifers, and birches (Cheeke, et al. 2016). Soil microbial processes such as nitrification differ among tree species, reflecting nutrient economy associated with the species. Trees with a more inorganic nutrient economy (commonly AM species) have greater $\mathrm{NO}_{3}{ }^{-}$losses due to the faster breakdown of the high quality, low $\mathrm{C}: \mathrm{N}$ litter (Phillips, Brzostek \& Midgley 2013). In turn, this may result in differing export of $\mathrm{NO}_{3}{ }^{-}$to streams through soil leaching (Peterjohn, et al. 2015), suggesting that watersheds dominated by slower $\mathrm{N}$ cycling trees such as ECM-associated oak species would have lower stream $\mathrm{N}$ exports relative to AM-dominated watersheds (Kelly, 2010; Phillips, Brzostek \& Midgley, 2013; Midgley \& Phillips 2014; Peterjohn, et al. 2015).

\subsection{Microbial Functional Genes}


Microbial functional genes may be used as a predictive tool in biogeochemical cycling and enhance the understanding of environmental changes within an ecosystem (Braker, et al. 2000; Bernhard, et al. 2010). The quantification of functional gene abundance can be used as a measure of the microbial community containing the specific gene. $\mathrm{N}$ cycling specific functional genes have been suggested as an index of potential nitrification and denitrification rates (Venterea, et al. 2004), as the abundance of functional microbial genes associated with $\mathrm{N}$ cycling in soil is a strong predictor of $\mathrm{N}$ transformation rates (Philippot, et al. 2009; Petersen, et al. 2012; Ribbons, et al. 2016). For example, a study examining tree species effect on gene abundance and $\mathrm{N}$ cycling rates documented a significant positive correlation between amo $A$ gene abundance and net nitrification (Ribbons, et al. 2016). Lab soil incubation studies have found that abundance of nirK is correlated to NO emissions, indicating nirK abundance is reflective of denitrification potential (Szukics, et al. 2009). The relative abundance of $\operatorname{nos} Z$ was shown to be a strong predictor of potential $\mathrm{N}_{2} \mathrm{O}$ production, as lower abundance of nos $Z$ correlated to a higher rate of $\mathrm{N}_{2} \mathrm{O}$ production (Philippot et al. 2009). Thus, structure and function of soil microbial communities play a large role in the cycling of $\mathrm{N}$, as the step-wise processes are highly controlled by metabolic capabilities of the microbial community but the relationship of $\mathrm{N}$ gene abundance and $\mathrm{N}$ process rates is largely unknown (Morales, Cosart, \& Holben, 2010; Petersen, et al., 2012; Levy-Booth, Prescott, \& Grayston, 2014; Rocca, et al., 2015, Ribbons, et al., 2016). This present study focuses on four key functional genes related to $\mathrm{N}$ transformation in soil, including amoA, nirK, nirS, and nosZ genes (Fig. 1), each of which is discussed briefly below.

Ammonia oxidation (amoA gene)

Chemolithotrophic ammonia oxidizers and nitrate oxidizers are required for the microbial process of nitrification (Levy-Booth, Prescott \& Grayston 2014), which is the oxidation of ammonia to nitrite $\left(\mathrm{NO}_{2}{ }^{-}\right)$and nitrate $\left(\mathrm{NO}_{3}{ }^{-}\right)(\mathrm{Fig}, 1)$. The amoA gene encodes for ammonia monooxygenase, the main catalyst for ammonia oxidation, the first step in the nitrification process (Levy-Booth, Prescott \& Grayston, 2014). Ammonia oxidation contributes to $\mathrm{N}_{2} \mathrm{O}$ emissions through direct production and by contributing to denitrification that generates $\mathrm{N}_{2} \mathrm{O}$ (Lehtovirta-Morley 2018). There are two categories of organisms that contain the amoA gene: ammonia oxidizing bacteria (AOB) and archaea (AOA). Functionality of AOB and AOA containing amoA genes are correlated with potential nitrification rate (Bernhard et al. 2007; Bernhard, et al. 2010). Environmental pH 
and $\mathrm{NH}_{3}{ }^{+}$concentration are key drivers of amoA abundance and diversity in ecosystems (Lehtovirta-Morley, 2018). Soil pH has been shown to affect the functionality and abundance of amoA bacterial species (Frijlink, et al. 1992). While nitrification still occurs in low $\mathrm{pH}$ soils, the bacterial community structure and function is altered compared to higher $\mathrm{pH}$ soils; Backman and Klemedtsson (2003) demonstrated an increase in nitrification and nitrifying bacteria following liming of soils. In another study, bacterial transcript abundance of amo $A$ increased with increasing $\mathrm{pH}$ in incubated microcosms (Nicol, et al. 2008). $\mathrm{N}$ fertilization can also alter the composition of the AOA and AOB communities (Hallin, et al. 2009; Wessen, et al. 2010) by increasing available $\mathrm{NH}_{4}{ }^{+}$; this allows for AOB to increase in abundance as AOB are typically limited by $\mathrm{NH}_{4}{ }^{+}$ availability (Backman \& Klemedtsson 2003).

\section{Nitrate reductase (nirK/S genes)}

Denitrification is the reduction of nitrate to nitrous oxide or dinitrogen; this is the process by which terrestrial $\mathrm{N}$ returns to atmospheric $\mathrm{N}$ (Fig. 1). The genes nirK and $\operatorname{nirS}$ catalyze the reaction of $\mathrm{NO}_{2}{ }^{-}$to $\mathrm{N}_{2} \mathrm{O}$ (Levy-Booth, Prescott \& Grayston 2014), and a change in the abundance of nirK/S can potentially drive $\mathrm{NO}_{3}{ }^{-}$and $\mathrm{NO}_{2}{ }^{-}$leaching from the environment (Barta, et al. 2010). The nirK and nirS genes are structurally different but functionally equivalent: $\operatorname{nir} K$ is copper $(\mathrm{Cu})$ containing while nirS is cytochrome containing (Braker, et al. 2000; Prieme, Braker, \& Tiedje, 2002). Due to the differences in structure, nirK/S are not found in the same organisms and thus have different biological niches (Braker et al. 2000; Jung, et al. 2011). Organisms containing either the nirK or nir $S$ gene are common in soil and the nirK/S abundance is influenced by soil temperature (Jung, et al. 2011), soil organic matter (Petersen, et al. 2012), biologically available N additions (Ouyang, et al. 2018), and soil pH (Hallin, et al. 2009). For example, in the Hallin et al. (2009) study, nirS abundance was significantly lower in fertilized acidic $(\mathrm{pH}=4.7)$ soils compared to the fertilized neutral $\mathrm{pH}(\mathrm{pH}=6.0)$ soils.

\section{Nitrous oxide reductase (nosZ gene)}

The reduction of $\mathrm{N}_{2} \mathrm{O}$ to dinitrogen $\left(\mathrm{N}_{2}\right)$ is the final step in denitrification catalyzed by nitrous oxide reductase encoded by the $\operatorname{nos} Z$ gene (Scala \& Kerkhof, 1998). nos $Z$ abundance has been shown to increase significantly with $\mathrm{N}$ fertilization (Ouyang, et al. 2018). Low soil pH is known to decrease nosZ abundance (Liu, Frostegard, \& Bakken, 2014; Aamar, et al. 2020), which in turn increases $\mathrm{N}_{2} \mathrm{O}$ emissions. Lab experiments on the model strain Paracoccus denitrificans 
demonstrated a post-transcriptional error in nos $\mathrm{Z}$ impacting protein synthesis under low $\mathrm{pH}$, leading to reduced functionality (Liu, Frostegard \& Bakken 2014), suggesting that bacteria may not have the capacity to reduce $\mathrm{N}_{2} \mathrm{O}$ to $\mathrm{N}_{2}$ in highly acidic $(\mathrm{pH}<5)$ soil, even if they possess the nos $Z$ gene.

\subsection{Research Objectives}

Our research aims were to quantify soil microbial gene abundance related to $\mathrm{N}$ cycling as influenced by long-term forest fertilization and in association with specific tree species, as well as to determine the relationship between gene abundance and production of $\mathrm{N}_{2} \mathrm{O}$ and $\mathrm{NO}_{3}{ }^{-}$in forest soil. We expected that the associated functional gene abundances would correspond to differences in $\mathrm{N}$ cycling resulting from long-term fertilization and acidification.

In the present study, soils sampled from two experimental forested watersheds in West Virginia. Watershed 3 (WS 3; fertilized) and Watershed 7 (WS 7; reference) in the Fernow Experimental Forest (FEF), were used to examine the abundance of the four key functional genes (amoA, nirK, nirS, and nos Z) in relation to $\mathrm{N}$ products measured in soil beneath four deciduous hardwood species. The tree species of interest were Northern red oak (Quercus rubra), sweet beech (Betula lenta) representing ECM-associated tree species; and tulip poplar (Liriodendron tulipifera), and black cherry (Prunus serotina), representing AM-associated tree species.

\subsection{Hypotheses}

Understanding how microbial functional genes contribute to the biogeochemical cycling is an important step in understanding ecosystem level processing of $\mathrm{N}$ and a critical research question for long-term fertilization sites. In many systems, differences in $\mathrm{N}$ cycling have been attributed to tree species (Lovett, et al. 2004; Midgley \& Phillips 2014) and the soil microbial community (Philippot, et al. 2009; Hang, et al. 2015; Ribbons et al. 2016). Surprisingly, nitrification rates in WS 3 in mineral soils do not vary from the reference watershed, even after 30 years of ammonium sulfate fertilization (Gilliam, et al. 2016; Carrara, et al. 2018; Gilliam, Adams, \& Peterjohn. 2020). To investigate the unexpected similarity in soil nitrification between WS 3 and WS 7, we measured $\mathrm{N}$ pools coupled with analyses of gene abundance in soil to test the following hypotheses: 
1) Soil beneath trees species with higher nitrification rates (AM-associated species) will have a higher abundance of the $\mathrm{N}$ cycling functional genes amoA, nirK, nirS, and nosZ. Nitrification is the process of converting $\mathrm{NH}_{4}{ }^{+}$to $\mathrm{NO}_{3}{ }^{-}$; thus, trees with higher nitrification rates will have a larger pool of available $\mathrm{N}$ for microbial transformation, allowing for the step-wise process involving the associated genes to occur.

2) Increased soil acidification resulting from long-term fertilization will alter microbial gene abundance involved in the production of $\mathrm{N}_{2} \mathrm{O}$ and $\mathrm{NO}_{3}{ }^{-}$. As soil becomes more acidic through elevated atmospheric deposition of $\mathrm{N}$, and $\mathrm{N}$ becomes available in excess of biological demand, the product ratio of $\mathrm{N}_{2} \mathrm{O}: \mathrm{N}_{2}$ trends upwards. The protein involved in the production of $\mathrm{N}_{2} \mathrm{O}$ (nosZ) is sensitive to soil acidity (Liu, et al. 2010), which leads to the prediction that the fertilized WS 3 will have lower $\operatorname{nos} Z$ gene abundance due to acidification from $\mathrm{N}$ fertilization, resulting in a higher rate of soil $\mathrm{N}_{2} \mathrm{O}$ production.

3) The abundance of the amoA, nirS and nirK functional genes will be positively correlated to the production of $\mathrm{NO}_{3}{ }^{-}$and $\mathrm{N}_{2} \mathrm{O}$ in soils, while nos $\mathrm{Z}$ abundance will be negatively correlated.

\section{Methods}

\subsection{Study Site}

The study site is located at the USDA Forest Service Fernow Experimental Forest (FEF), a temperate mixed hardwood forest, located in north central West Virginia, USA (Fig. 2). Dominant tree species are black cherry, tulip poplar, sweet birch, and northern red oak (Gilliam, et al. 2016). Understory vegetation consists of common greenbrier (Smilax rotundifolia), Sassafras (Sassafras albidum), Woody nettle (Laportea canadensis) and several blackberry species (Rubus spp.) (Gilliam \& Turrill, 1993; Gilliam, 2021). Climate of the study area is classified as humid continental with hot summers, cold winters, and abundant precipitation (Lockwood, 1985). Average annual precipitation is $1430 \mathrm{~mm}$, with the greatest amount occurring in the spring and summer months (Gilliam et al. 2001). The FEF lies in the Allegheny Mountain section of the unglaciated Appalachian Plateau. The dominant soil series of the FEF is classified as the Calvin series, derived from sandstone and shale, leading to well-drained, medium-textured loams and silt loams (Peterjohn, Adams and Gilliam 1996). The Calvin series is a loamy-skeletal, mixed, active, mesic Typic Dystrudept (Web Soil Survey, USDA), with typically low base saturation, a thin, 
poorly developed A horizon, and a weakly- to moderately-developed B horizon (USDA 2014). Soil $\mathrm{pH}$ in the FEF watersheds is relatively low due to the underlying geology of shale and sandstone, as well as the history of elevated $\mathrm{N}$ and $\mathrm{S}$ deposition; $\mathrm{N}$ deposition averaged about 10 $\mathrm{kg} \mathrm{ha}^{-1} \mathrm{yr}^{-1}$ (Gilliam et al. 2016).

We assessed long-term fertilization effects at two forested watersheds within the FEF (Fig. 2). Watershed 3 (WS 3) is a 34-hectare watershed that had been receiving aerial application of additional $\mathrm{N} 35 \mathrm{~kg} \mathrm{~N} \mathrm{yr}^{-1}$ as ammonium sulfate $\left(\left(\mathrm{NH}_{4}\right)_{2} \mathrm{SO}_{4}\right)$ fertilizer three times a year from 1989 until 2019 (Adams, Kochenderfer \& Edwards, 2007). Watershed 7 (WS 7) is a 24-hectare watershed which has been allowed to naturally regenerate since 1969 after being clear-cut in sections from 1964 until 1967. Following harvest in WS 7, it was maintained as barren with herbicides until 1969. WS 7 serves as the vegetative reference watershed for WS 3 in numerous watershed studies (Adams, Kochenderfer \& Edwards, 2007).

\subsection{Field sampling}

Four trees of four species (northern red oak, sweet birch, tulip poplar, and black cherry) were located and marked in both watersheds during the Fall of 2018 (see Fig. 2). Selected trees had a minimum diameter at breast height $(\mathrm{DBH})$ of $16.25 \mathrm{~cm}$, were visibly healthy, and of dominant canopy position. Tree species were selected to represent both dominant types of mycorrhizal association: Northern red oak and sweet birch are ECM-associated species, tulip poplar and black cherry are AM-associated species. Black cherry is the dominant species in WS 3 but not in WS 7, making it of special interest. Five soil samples were collected from the mineral A horizon (0-10 $\mathrm{cm}$ ) under the drip line of each individual tree using a randomized collection approach (Peterjohn, et al. 2015). These subsamples were combined in the field to obtain one sample per tree $(\mathrm{n}=2$ watersheds; $\mathrm{n}=4$ tree species; $\mathrm{n}=4$ individual trees; $\mathrm{N}=32$ samples). All soil sampling took place over the course of one week in July 2020, corresponding to peak growth season. Sampling occurred after the last fertilization, but this is not a post- fertilization study as the watershed is not considered in the recovery stage at this time point. Moist samples were sieved with a $2 \mathrm{~mm}$ mesh sieve to remove roots and coarse debris and stored in a $4{ }^{\circ} \mathrm{C}$ cold room. Subsamples for DNA processing were stored at $-20{ }^{\circ} \mathrm{C}$ until extraction.

\subsection{Soil characteristics}


To determine the effect of long-term fertilization on soil properties, soil physiochemical characteristics were analyzed that have been shown to affect plant and microbial function. Soil moisture content was determined gravimetrically, where $10 \mathrm{~g}$ of field-moist soil was dried at 105 ${ }^{\circ} \mathrm{C}$ for $24 \mathrm{~h}$. Following drying, samples were re-weighed to determine dry mass. To determine soil organic matter (SOM) via loss on ignition (LOI), $10 \mathrm{~g}$ of field-moist soil was combusted at $500{ }^{\circ} \mathrm{C}$ for $12 \mathrm{~h}$ in a muffle furnace and allowed to cool. Following combustion and cooling, samples were reweighed, and weight adjusted for moisture content. Soil $\mathrm{pH}$ was measured using a 1:5 soil to $0.01 \mathrm{M} \mathrm{CaCl}_{2}$ solution and $\mathrm{CaCl}_{2}$ is used to mimic soil solution ionic composition. $5 \mathrm{~g}$ of air-dried soil were placed in $10 \mathrm{~mL} 0.01 \mathrm{M} \mathrm{CaCl}_{2}$, shaken at room temperature for 30 minutes, and allowed to settle for 1 hour before reading solution by a $\mathrm{pH}$ electrode (GENERAL digital, Taiwan).

To determine inorganic $\mathrm{N}\left(\mathrm{NH}_{4}{ }^{+}\right.$and $\left.\mathrm{NO}_{3}{ }^{-}\right)$concentration in soils, samples were extracted using an extraction of $10 \mathrm{~g}$ field moist soil in $40 \mathrm{~mL}$ of $2 M \mathrm{KCl}$ solution. Samples were shaken for 1 hour, allowed to settle, and supernatant was filtered through Whatman 2 filters. Quantification of $\mathrm{NH}_{4}{ }^{+}$and $\mathrm{NO}_{3}{ }^{-}$in filtered solutions was performed colorimetrically in 96-well plates on Synergy HTX plate reader (Biotek, Winooski, VT).

Extractable $\mathrm{NH}_{4}{ }^{+}$was determined using $2 M \mathrm{KCL}$ extraction samples followed by $150 \mu \mathrm{L}$ sodium salicylate and $150 \mu \mathrm{L}$ sodium hydroxide bleach solution, absorbance values were read at $650 \mathrm{~nm}$ on the plate reader after a 50-minute incubation at room temperature (Deforest, 2011). All samples were run in quadruple and standard curves were generated for each plate. Sample weights were corrected for moisture content post analysis.

Extractable $\mathrm{NO}_{3}{ }^{-}$was determined using colorimetric reagents of 2:1:1 vanadium $\left(\mathrm{VCl}_{3}\right), 2 \%$ sulfanilamide and $0.1 \%$ NEDD solution; absorbance was read at $540 \mathrm{~nm}$ following incubation at $20{ }^{\circ} \mathrm{C}$ (Deforest 2011). All samples were run in quadruple and standard curves were generated for each plate. Sample weights were corrected for moisture content.

Potential $\mathrm{N}_{2} \mathrm{O}-\mathrm{N}$ emissions were measured using an $\mathrm{N}_{2} \mathrm{O}$ microsensor (Unisense, Germany) using a modified acetylene $\left(\mathrm{C}_{2} \mathrm{H}_{2}\right)$ inhibition technique (Liu, et al. 2018; Kaden, et al. 2020). $\mathrm{C}_{2} \mathrm{H}_{2}$ is known to inhibit the reduction of $\mathrm{N}_{2} \mathrm{O}$ to $\mathrm{N}_{2}$ (Estavillo, et al. 2002) and allows for the determination of the total denitrification rate $\left(\mathrm{N}_{2} \mathrm{O}+\mathrm{N}_{2}\right) .10 \mathrm{~g}$ of field moist soil was weighed out and added to a $50 \mathrm{ml}$ vial with $35 \mathrm{ml}$ of $\mathrm{KNO}_{3}$ glucose nutrient solution (Liu, et al. 2018) and $8 \mathrm{ml} \mathrm{C}_{2} \mathrm{H}_{2}$ was injected to create a $15 \%$ environment of acetylene. A control was analyzed for each sample where 
$8 \mathrm{~mL}$ oxygen was added instead of $\mathrm{C}_{2} \mathrm{H}_{2}$. $\mathrm{N}_{2} \mathrm{O}-\mathrm{N}$ concentration readings were taken at $1 \mathrm{hr}, 18 \mathrm{hr}$, $22 \mathrm{hr}$, and $36 \mathrm{hr}$ by piercing the vial septum with the sensor needle. All readings were recorded after $60 \mathrm{~s}$ equilibration in the sample solution.

\subsection{DNA extraction}

DNA was extracted using $0.25 \mathrm{~g}$ field moist soil using the Qiagen PowerSoil DNA Extraction kit (Qiagen, Germany). DNA concentration $(\mathrm{ng} / \mu \mathrm{L})$ per sample was quantified using a Qubit fluorometer following the manufacturer's protocol using $197 \mu 1$ buffer and $3 \mu 1$ sample. DNA samples were stored at $-20^{\circ} \mathrm{C}$.

\subsection{Functional gene analysis}

We determined the effect of experimental $\mathrm{N}$ fertilization and the influence of tree species on bacterial gene abundance using quantitative polymerase chain reaction (qPCR) on the four key genes of interest (amoA, nirK, nirS, and nosZ). Table 1 summarizes the primers and reference strains used for each gene.

For genomic DNA isolation, Pseudomonas fluorescens, Alcaligenes faecalis, Paracoccus denitrificans, and Pseudomonas stutzeri were obtained through the USDA ARS culture collection and used as reference strains to obtain the gene segments with standard PCR (Table 1). Reference strains were grown in liquid media according to ARS specifications and genomic DNA was extracted using the ThermoFisher GeneJET Genomic DNA Extraction kit (ThermoFisher). Primers from the pure reference cultures and amplified using standard PCR using the following protocol. Standard curves for qPCR were generated from plasmid standards. Cloning of plasmid standards was done using Invitrogen TA Cloning kit pCR2.1 Topo.

Standard PCR was used to obtain amplified product for each gene of interest. $25 \mu$ standard PCR reactions were run, using $12.5 \mu \mathrm{l}$ Amplitaq Gold Master Mix (2x concentration), $1 \mu$ l Forward Primer $(10 \mathrm{u} M), 1 \mu \mathrm{l}$ Reverse Primer $(10 \mathrm{u} M), 9.5 \mu \mathrm{dH} 2 \mathrm{O}, 1 \mu 1$ template DNA. The following amplification conditions were used: Stage $1: 95^{\circ} \mathrm{C}$ for $1 \mathrm{~min}, 1 \mathrm{x}$ cycle Stage $2: 95^{\circ} \mathrm{C}$ for $1 \mathrm{~min}$, $55^{\circ} \mathrm{C}$ for $30 \mathrm{sec}, 72^{\circ} \mathrm{C}$ for $30 \mathrm{sec}, 35 \mathrm{x}$ cycles Stage $3: 72^{\circ} \mathrm{C}$ for $7 \mathrm{~min}, 4^{\circ} \mathrm{C}$ hold, $1 \mathrm{x}$ cycle (Biorad, USA). PCR reactions were run on a 1\% agarose gel and visualized using SyberSafe (Promega, USA) to confirm the amplicon size. Bands were excised and purified using the Wizard clean up 
kit (Promega, USA), then cloned using the Invitrogen TA Cloning kit PCR2.1. Individual colonies were picked and plasmid DNA purified using the Zippy DNA kit (ZYMO, USA). Plasmid DNA was sent to the WVU Genomics Core Lab for Sanger sequencing using M13 primers to verify insert sequence. Standard curves for qPCR were developed by serially diluting plasmid DNA to final concentrations between $1 \times 10^{1}$ to $1 \times 10^{8}$ copies $\mu 1^{-1}$.

Touchdown PCR was attempted for amoA $\left(50^{\circ} \mathrm{C}-60^{\circ} \mathrm{C}\right)$ with primers amoA $1 \mathrm{~F}$ mod and GenAOB R, and $\operatorname{nirS}\left(52^{\circ} \mathrm{C}-62^{\circ} \mathrm{C}\right)$ with primers nirS $4 \mathrm{~F}$ and nirS $5 \mathrm{R}$, as standard PCR failed to amplify these gene targets. Touchdown PCR and standard PCR were also run using Promega Gotaq Green mastermix for nirS and amoA to determine if the polymerase was an issue. Touchdown PCR was not run for nirK or nos $Z$ as amplification was successful using the standard approach.

For qPCR, a $10 \mu \mathrm{L}$ final reaction volume was used, containing $2 \mu \mathrm{L}$ of PCR grade water, $0.5 \mu \mathrm{L}$ of forward and reverse primer (total primer concentration $=500 \mathrm{n} M$ ), $5 \mu \mathrm{L}$ of SYBER qPCR $2 \mathrm{X}$ master mix, and $1 \mu \mathrm{L}$ of template DNA. For all functional genes, real time amplification was performed using the following conditions: stage $1: 95^{\circ} \mathrm{C}$ for 5 minutes $1 \mathrm{x}$ stage $2: 95{ }^{\circ} \mathrm{C}$ for $20 \mathrm{~s}$ and $60{ }^{\circ} \mathrm{C}$ for $45 \mathrm{~s} 35 \mathrm{x}$ stage $3: 95^{\circ} \mathrm{C}$ for $15 \mathrm{~s} 1 \mathrm{x}$. To assess the specificity of the PCR reaction a melt-curve was analyzed for each target gene (Fig. S1 - S2). Assays were run in 96-well plates with three replicates for each sample, positive and negative control. The number of gene copies (CN) was calculated by comparing measured values to genomic DNA of pure cultures with a known genome size and gene copy number.

\subsection{Statistical Analysis}

Differences in $\mathrm{NO}_{3}{ }^{-}, \mathrm{NH}_{4}{ }^{+}, \mathrm{N}_{2} \mathrm{O}$, soil $\mathrm{pH}$, nirK abundance, and nos $\mathrm{Z}$ abundance attributed to fertilization or tree species were analyzed using nonparametric tests. Non-parametric analysis was used due to the lack of normality for the distribution of data. Wilcoxon tests were run for watershed comparisons, pair-wise Wilcox tests were run for tree species comparisons within each watershed and a significance level of $<0.05$ was used to indicate statistical significance. Simple correlation was preformed using Pearson's correlation coefficient to examine linear relationships between variables. 
All data was analyzed using R-studio v.1.4 with packages dplyr and tidyr for data organization, ggpubr for figure creation, and statix for statistical analysis. This watershed comparison study is an example of experimental pseudo-replication with an effective sample size of one. Differences in data are assumed to be a result of fertilization effects because 1) the soil descriptions in each watershed are predominantly the same and 2) previous analyses of soils in the watersheds indicate that changes primarily occurred after fertilization started in 1989 (Adams and Angradi 1996).

\section{Results}

\subsection{Inorganic soil $N$}

Soil inorganic $\mathrm{N}\left(\mathrm{NH}_{4}{ }^{+}\right.$and $\left.\mathrm{NO}_{3}{ }^{-}\right)$concentrations from the two watersheds are similar $(\mathrm{p}>0.05$; Fig. $3 \mathrm{~b}$ and c). Mean $\mathrm{NH}_{4}{ }^{+}$concentrations were $9.45\left(\mathrm{mg} \mathrm{N} \mathrm{kg}^{-1}\right)$ in WS3 and $7.84\left(\mathrm{mg} \mathrm{N} \mathrm{kg}^{-1}\right)$ in WS7 (Table 2). Soil $\mathrm{NH}_{4}{ }^{+}$concentrations under black cherry within WS 3 were significantly $(\mathrm{p}=$ 0.03) higher than tulip poplar and northern red oak (Fig. 4). Mean $\mathrm{NO}_{3}{ }^{-}$concentrations were not statistically distinct between watersheds (Table 2), WS 3 mean $\mathrm{NO}_{3}{ }^{-}$was $35.37\left(\mathrm{mg} \mathrm{N} \mathrm{kg}^{-1}\right)$ and $34.55\left(\mathrm{mg} \mathrm{N} \mathrm{kg}^{-1}\right)$ in WS 7. Soil $\mathrm{NO}_{3}{ }^{-}$concentrations within WS 7 were distinct by tree species, as soil beneath tulip poplar contained significantly more $\mathrm{NO}_{3}{ }^{-}(\mathrm{p}=0.02)$ than soil $\mathrm{NO}_{3}{ }^{-}$concentrations beneath sweet birch (Fig. 5). Soils beneath sweet birch have a mean $\mathrm{NO}_{3}{ }^{-}$concentration of 16.94 (mg N kg${ }^{-1}$ ) and soils beneath tulip poplar have an average mean of $46.73\left(\mathrm{mg} \mathrm{N} \mathrm{kg}^{-1}\right)$ (Table 2) in WS 7. However, soil $\mathrm{NO}_{3}{ }^{-}$did not vary by tree species in WS 3. $\mathrm{NO}_{3}{ }^{-}$concentrations in soil beneath AM-associated trees in WS 7 was higher, though not significantly so $(p=0.05)$, compared to ECM-associated species in the same watershed (Fig. 6). No statistically significant difference in inorganic $\mathrm{N}$ between fungal association was observed in WS 3.

\subsection{Soil pH, SOM, and Moisture}

Soil pH varied significantly by watershed (Fig. 3 a), as mean soil pH was 3.98 in WS 3 and 4.35 in WS $7(\mathrm{p}<0.001)$. There were no statistically significant differences in soil $\mathrm{pH}$ between tree species in either WS 3 or WS 7 (Table 2). Percent SOM did not significantly differ between watersheds or tree species within watershed (Table 2). Soil moisture also did not vary between watersheds or by tree species (Table 2).

\subsection{Soil $\mathrm{N}_{2} \mathrm{O}$ potential}


Potential $\mathrm{N}_{2} \mathrm{O}$ production increased throughout the 36-hour incubation period in all soils, with $\mathrm{R}$ values of 0.73 indicating a positively linear relationship of $\mathrm{N}_{2} \mathrm{O}$ production over the 36-hour incubation (Fig. 7). Potential cumulative $\mathrm{N}_{2} \mathrm{O}$ concentrations did not significantly differ between watersheds (Fig. 3 b). Average potential $\mathrm{N}_{2} \mathrm{O}$ for WS 3 was $0.32\left(\mathrm{mg} \mathrm{N} \mathrm{kg}^{-1}\right)$. Within WS 3 , tree species mildly $(\mathrm{P}=0.057)$ influenced potential $\mathrm{N}_{2} \mathrm{O}$ production, as soil beneath sweet birch trended higher than soils beneath red oak but were not statistically significant from sweet birch soil, producing an average of $0.47\left(\mathrm{mg} \mathrm{N} \mathrm{kg}^{-1}\right)$ and red oak soil produced $0.18\left(\mathrm{mg} \mathrm{N} \mathrm{kg}^{-1}\right)$ (Table 2). Tree species did not affect potential $\mathrm{N}_{2} \mathrm{O}$ production in WS 7 .

\subsection{Gene Abundance}

Soils in WS 7 had significantly $(\mathrm{p}<0.01)$ greater abundance of nos $Z$ than WS 3 (Fig. 9). WS 7 soil contained a mean of $1.14 \times 10^{11}$ copies ng of DNA per gram of soil $\left(\mathrm{CN} \cdot \mathrm{ng} \mathrm{g}^{-1}\right)$ and WS 3 soil contained $2.24 \times 10^{11} \mathrm{CN} \cdot \mathrm{ng} \mathrm{g}^{-1}$ (Table 2). nos $Z$ abundance did not differ significantly among tree species (Table 2) or fungal association (Fig. 10) in either watershed.

WS 7 soil contained a significantly $(\mathrm{p}<0.01)$ greater mean abundance of $n i r K$ relative to WS 3 $2.28 \times 10^{12} \mathrm{CN} \cdot \mathrm{ng} \mathrm{g}^{-1}$ and $6.70 \times 10^{10} \mathrm{CN} \cdot \mathrm{ng} \mathrm{g}^{-1}$, respectively (Fig. 9). Within watersheds, nirK abundance did not differ significantly among tree species (Table 2). Soil beneath AM-associated species in WS 3, while not statistically significant $(\mathrm{p}=0.05)$, had lower abundance of nirK (Fig 10) relative to soil beneath ECM-associated species, though no differences were noted between fungal association in WS 7.

The ratio of nirK:nosZ (a higher ratio is reflective of greater $\mathrm{N}_{2} \mathrm{O}$ production potential) was significantly higher $(\mathrm{p}=0.011)$ in soil from WS 7 (Fig. 9) with an average of $6.41 \times 10^{5}$ of nirK:nosZ compared to WS 3 ratio of 131.80 (Table 2). There were no nirK:nos $Z$ differences among tree species between individual watersheds (Table 2).

\subsection{Relationships of Environmental Variable to Gene Abundance}

Overall, nirK abundance exhibited a significant positive relationship with soil $\mathrm{pH}$ across both watersheds $(\mathrm{p}<0.01)$, however, within the individual watersheds this relationship was not statistically significant (Fig. 11). nos $Z$ abundance also exhibited a significant positive relationship 
with soil $\mathrm{pH}$ across both watersheds $(\mathrm{p}=0.02)$, however, within the individual watersheds this relationship was not observed (Fig. 11).

There was no correlation between gene abundance and soil $\mathrm{NH}_{4}{ }^{+}$concentration (Fig. 12). In WS $3, \mathrm{~N}_{2} \mathrm{O}$ production was negatively related to soil $\mathrm{pH}(\mathrm{p}=0.03)$, with lower $\mathrm{N}_{2} \mathrm{O}$ production with increasing soil $\mathrm{pH}$ (Fig. 8). No correlation occurred between gene abundance and potential $\mathrm{N}_{2} \mathrm{O}$ production across all samples (Fig. 13). Overall, no correlation was seen between gene abundance and soil $\mathrm{NO}_{3}{ }^{-}$concentration across watersheds (Fig. 14). There was also no correlation between nirK:nos $Z$ at the watershed level in relation to $\mathrm{N}_{2} \mathrm{O}$ production (Fig. 15).

Although many attempts and conditions were used, amo $A$ and nirS were not successfully quantified and were thus removed from this study, as the standard PCR amplification was not successful (Table 3). Primers pairs AmoA189, AmoA682 and Cd3af, NirsR3cd amplified at 525 bp and $425 \mathrm{bp}$, respectively, but qPCR is not successfully run with fragment sizes above 300bp. Primer sets for amoA; AmoA1F, AmoA2R,GENAOB F, GENAOB R, and GEN AOB mod did not successfully amplify using a $55^{\circ} \mathrm{C}$ annealing temperature, touchdown PCR using a gradient of $50^{\circ} \mathrm{C}$ to $60{ }^{\circ} \mathrm{C}$, or use of Gotaq green mastermix. Primer set nirS4F and nirS5Rdid not successfully amplify at a $55{ }^{\circ} \mathrm{C}$ annealing temperature, touchdown PCR using a gradient of $52{ }^{\circ} \mathrm{C}$ to $62{ }^{\circ} \mathrm{C}$ or use of Gotaq green mastermix. Electrophoresis gels for all PCR attempts can be found in the supplemental information (Fig. S3 - S8).

\section{Discussion}

\subsection{Nitrogen dynamics}

The processes of the $\mathrm{N}$ cycle are closely interlinked and have direct influence on each other (Fig 1). Due to the interconnectedness of the $\mathrm{N}$ cycle, an alteration at one step may impact the resultant end product and subsequent steps. Addition of $\mathrm{NH}_{4}^{+}$fertilizer impacts the subsequent $\mathrm{N}$ transformations due to an increased pool of $\mathrm{N}$ for downstream transformations. Surprisingly, no measurable differences were observed in the $\mathrm{NH}_{4}{ }^{+}, \mathrm{NO}_{3}{ }^{-}$, or $\mathrm{N}_{2} \mathrm{O}$ pools at the watershed level (Fig. 3).

It was expected that the fertilized watershed WS 3 would exhibit higher soil concentrations of $\mathrm{NH}_{4}{ }^{+}, \mathrm{NO}_{3}{ }^{-}$, and $\mathrm{N}_{2} \mathrm{O}$ compared to WS 7, the reference watershed. 
Soil pH is significantly different between the watersheds with WS 3 being more acidic (Fig. 3 a). While WS 3 is highly acidic with an average $\mathrm{pH}$ of 3.88 it is important to keep in mind that soils in WS 7 are also considered acidic. Both watersheds functionally are described as acidic soils (pH $<5.0$ ) in terms of biogeochemical processes (Deforest, et al. 2012; Shetty \& Prakash, 2020). Acidic soils are known to impact soil properties (Ollivier, et al. 2011; Graham, et al. 2014), such as microbial processes and nutrient availability, and nutrient losses (Shetty \& Prakash 2020). Acidity is produced when $\mathrm{NH}_{3}{ }^{+}$containing materials such as $\mathrm{N}$ fertilizers are transformed to $\mathrm{NO}_{3}{ }^{-}$in the soil. WS 3 received consistently elevated amounts of $\mathrm{N}$ fertilizer each year, thus it was expected that WS 3 would have measurably higher $\mathrm{NH}_{4}{ }^{+}$and $\mathrm{NO}_{3}{ }^{-}$.

In this study, no significant differences in inorganic $\mathrm{N}$ contents were observed at the watershed scale in the mineral A horizon (Table 2). Soil analyses from 2015 in these same watersheds demonstrated a significantly greater amount of $\mathrm{NH}_{4}{ }^{+}$and $\mathrm{NO}_{3}{ }^{-}$in WS 3 , contrary to our findings (Gilliam, Adams and Peterjohn 2020), which could be due to more intensive sampling at multiple time points. Carrara et al. (2018) found that nitrification in the organic (O) horizon in WS 3 was $51 \%$ higher, but detected no difference in $\mathrm{N}$ transformation rates in the mineral soil between WS 3 and WS 7, which is consistent with our results. O horizon soil and mineral soil have differing chemical and biological properties such as organic matter content, root densities, and microbial compositions (Brzostek and Finzi 2011). In the current study, no differences in SOM between watersheds were observed (Table 2), which is also supported by results from Gilliam et al. (2020), showing a similar OM content in soil from WS 3 and WS 7.

At the tree species level, soils beneath black cherry contained significantly more $\mathrm{NH}_{4}{ }^{+}$within WS 3 (Fig. 4). Black cherry, an $\mathrm{AM}$-associated species, is a $\mathrm{NO}_{3}{ }^{-}$demanding species and does not utilize $\mathrm{NH}_{4}{ }^{+}$as efficiently as other co-occurring species (Royo, et al. 2021), which could result in residual $\mathrm{NH}_{4}{ }^{+}$from fertilization accumulating in the soil. Soils beneath sweet birch produced significantly less $\mathrm{NO}_{3}{ }^{-}$than tulip poplar within WS 7 (Fig. 5). Sweet birch is an ECM-associated species while tulip poplar is an AM-associated species. ECM species typically have less soil $\mathrm{NO}_{3}{ }^{-}$ loss compared to AM species due to the development of a more organic nutrient economy (Phillips, Brzostek and Midgley 2013).

Soils on plots dominated by AM-tree species have been shown to have higher $\mathrm{NO}_{3}{ }^{-}$concentration than ECM-dominated plots (Midgley and Phillips 2014). AM-associated tree species produce litter 
that is more easily decomposed compared to ECM associated species; this leads to larger pools of inorganic $\mathrm{N}$ such as $\mathrm{NO}_{3}{ }^{-}$in the soil (Cheeke, et al. 2016). Black cherry and tulip poplar are AMassociated species which are known to have a relatively faster nitrification rate than ECMassociated species (Phillips, Brzostek \& Midgley 2013); this would lead to a larger pool of bioavailable $\mathrm{N}$ in the soil. This effect is observed within WS 7, as soil beneath AM-associated species have a significantly higher concentration of $\mathrm{NO}_{3}{ }^{-}$, relative to $\mathrm{ECM}$-associated species (Fig. 6). This effect was not observed in WS 3, which supports the idea that fertilization decreases the effect of fungal association (Midgley \& Phillips, 2014) and fertilization may result in a homogenization of $\mathrm{N}$ cycling and other biogeochemical processes (Wu, et al. 2019). Fungal biomass can also decrease in response to $\mathrm{N}$ fertilization (Treseder, 2004; Zhang, Chen \& Ruan, 2018), as $\mathrm{N}$ limitation is alleviated through fertilization, the need for the host species to allocate nutrients belowground to associated fungi decreases (Treseder, 2008), causing a decrease in fungal biomass and limiting the metabolic influence of AM and ECM fungi on $\mathrm{N}$ transformations (Wallenstein, et al. 2006).

It was surprising to observe similar rates of $\mathrm{N}_{2} \mathrm{O}$ produced in both watersheds (Fig. $7 \mathrm{a}$ and b), as WS 3 is significantly more acidic which has been shown to be an important factor in increased $\mathrm{N}_{2} \mathrm{O}$ production (Firestone \& Davidson, 1989). This could be due to the selected methodology of $\mathrm{N}_{2} \mathrm{O}$ production as a nutrient solution was used to stimulate microbial respiration for potential $\mathrm{N}_{2} \mathrm{O}$, which may not reflect field conditions. In a 1998 study, field measures of $\mathrm{N}_{2} \mathrm{O}$ in WS 3 exhibited significant spatial variability with certain soil cores having $60 \%$ less $\mathrm{N}_{2} \mathrm{O}$ from a plot lower in the watershed (Peterjohn, et al. 1998). In the current study, $\mathrm{N}_{2} \mathrm{O}$ emissions were positively correlated with soil $\mathrm{NO}_{3}{ }^{-}$concentration across both watersheds, indicating increasing $\mathrm{NO}_{3}{ }^{-}$ increases $\mathrm{N}_{2} \mathrm{O}$ production (Fig. 8 c). This is explained by Firestone and Davidson's (1989) "hole in the pipe" theory, which suggests that increasing amounts of $\mathrm{NO}_{3}{ }^{-}$in the soil directly results in elevated $\mathrm{N}_{2} \mathrm{O}$ emissions.

\subsection{Fertilization Influence on Gene Abundance}

Though there are few differences in measured soil properties between the watersheds, we documented a significant reduction in both nirK and nos $Z$ gene abundance in the fertilized watershed, WS 3 (Fig. 9). nos $Z$ gene abundance was significantly lower in WS 3 relative to WS 7 (Fig. 9 b), but nos $Z$ abundance was not correlated to potential denitrification rates (Fig. 13 a). This 
finding supports our hypothesis that increased soil acidification would alter nitrification associated gene abundance leading to WS 3 having decreased nos $Z$ abundance. Several studies (Dandie, et al. 2008; Attard, et al. 2010) have also shown that nos $Z$ abundance was not significantly associated with potential denitrification rates. However, to the contrary, several studies previously linked nos $Z$ abundance to potential denitrification rates (Hallin, et al. 2009; Petersen, et al. 2012). The functionality of $\mathrm{N}_{2} \mathrm{O}$ reductase encoded by nos $\mathrm{Z}$ has been shown to be inhibited at low $\mathrm{pH}(\mathrm{pH}<$ 6.1), whether by a mutation causing silencing of the gene or an assembly issue within the bacterial cell, the cause of impaired nos $Z$ at low pH is poorly understood (Liu, Frostegard, \& Bakken 2014). While significant differences in gene abundance were observed between the watersheds, cumulative $\mathrm{N}_{2} \mathrm{O}$ production did not differ significantly (Fig. $3 \mathrm{~d}$ ). The abundance of $\operatorname{nos} \mathrm{Z}$ and $\operatorname{nirK}$ functional genes were not correlated to the production of $\mathrm{NO}_{3}{ }^{-}$(Fig. 14) or to potential $\mathrm{N}_{2} \mathrm{O}$ production (Fig.13) in soil within our study.

In multiple studies, the total nirS and nirK abundance is used as an indicator of the total denitrifier population present (Philippot, et al. 2009; Hallin, et al. 2009), as nirS is functionally identical to nirK but structurally different. Organisms that contain $\operatorname{nirS}$ do not generally also contain $\operatorname{nirK}$ (Levy-Booth, Prescott \& Grayston, 2014; Ribbons), thus the total nirK/S abundance is used for an estimate of nitrate reductase in multiple studies. Although nirK is significantly lower in WS 3 (Fig. $9 \mathrm{c}$ ), this does not necessarily mean that nitrate reductase is lacking in WS 3 soils, it is plausible that $\operatorname{nir} S$ is the dominant denitrifying gene and we were not able to produce satisfactory results to quantify nirS abundance. Thus, nirS abundance may be an important indicator of process rates in these forest soils and could better account for $\mathrm{N}_{2} \mathrm{O}$ emissions observed between the watersheds (Fig. 9), though we were not able to quantify nirS in the present study.

The ratio of nirK:nos $Z$ has previously been used as an indicator of endpoint $\mathrm{N}_{2} \mathrm{O}$ production (Philippot, 2002), though the ratio of nirK:nos $Z$ was not correlated to potential $\mathrm{N}_{2} \mathrm{O}$ production in this study (Fig. 15). The watersheds demonstrated significant difference in nirK:nosZ (Fig. 9 c) but no significant difference in potential $\mathrm{N}_{2} \mathrm{O}$ production (Fig. 3 d), indicating the ratio of nirK:nos $Z$ was not indicative of $\mathrm{N}_{2} \mathrm{O}$ production here. Previous studies (Hallin, et al. 2009; Philippot, et al. 2011; Qin, et al. 2020) have also not detected a significant correlation between the proportion of denitrifying genes and $\mathrm{N}_{2} \mathrm{O}$ production. 
Contrary to our hypothesis, concentrations of $\mathrm{NH}_{4}^{+}$(Fig. 12), $\mathrm{N}_{2} \mathrm{O}$ (Fig. 13) and $\mathrm{NO}_{3}^{+}$(Fig. 14) were not correlated to any measured gene abundance. The enzymes produced by organisms containing these genes mediate $\mathrm{N}$ transformations (Morales, Cosart, \& Holben, 2010), which makes it surprising that no significant relationship was observed at the watershed level. However, measures of amoA gene abundance may be better related to $\mathrm{NH}_{4}{ }^{+}$and $\mathrm{NO}_{3}{ }^{-}$, as it encodes for the enzyme production responsible for the oxidation of ammonium, though we were unable to successfully quantify amoA in our study.

The ability to use gene abundance as an indicator of potential $\mathrm{N}$ cycling rates is still unresolved, as (Graham, et al. 2014), as gene presence does not necessarily indicate community functionality (Levy-Booth, Prescott \& Grayston, 2014). DNA based analysis such as qPCR does not differentiate between dormant and active DNA sources (Levy-Booth, Prescott \& Grayston, 2014). Available primers for functional genes are unlikely to capture the full diversity of the target genes in environmental samples for which they are designed, as sequences are derived from singular organisms (Green, et al. 2010; Levy-Booth, Prescott \& Grayston, 2014). It has previously been shown (Liu, Frostegard, \& Bakken 2014) that the assembly of functional $\mathrm{N}_{2} \mathrm{O}$ reductase is altered in acidic soil, but not necessarily the relative abundance of the nos $Z$ gene. Liu (2014) explored $\mathrm{N}_{2} \mathrm{O}$ reductase functionality in soils ranging from $\mathrm{pH}$ of 4.0 to 8.0 and reported soils with $\mathrm{pH}<$ 6.1 were unable to produce functional $\mathrm{N}_{2} \mathrm{O}$ reductase in a laboratory setting. It is hypothesized that organisms containing nos $\mathrm{Z}$ are inhibited by low $\mathrm{pH}$, which decreases their abundance and capability to reduce $\mathrm{N}_{2} \mathrm{O}$ (Liu, Frostegard \& Bakken 2014). Shifts in specific gene composition are not necessarily directly correlated to shifts in measurable functions such as $\mathrm{N}$ transformations, as the active bacterial community may differ from the total community (Freedman, et al. 2015; Moore, et al. 2020).

\subsection{Tree Species Influence on Gene Abundance}

Few significant differences occurred in measured soil parameters or gene abundance as a function of tree species in either watershed in this study. Gene abundance did not differ significantly among tree species in either watershed (Table 2). This contrasts with the study by Kelly, et al. (2021), where tree species did significantly alter the gene abundance of multiple key genes in the $\mathrm{N}$ cycle. Although black cherry had a higher nirK and nos $Z$ abundance than American chestnut, no significant difference between soil beneath red oak and black cherry nirK and nos $Z$ abundance was 
found. This could indicate that soils beneath black cherry and red oak are more similar in soil properties influencing $\mathrm{N}$ transformations than soil beneath chestnut.

Soils beneath black cherry trees had a higher amount of $\mathrm{NH}_{4}{ }^{+}$suggesting an altered nitrification rate. While soils beneath black cherry did not differ significantly in gene abundance, nirK in soils beneath black cherry in WS 3 was highly suppressed (Fig. 9 a), which could indicate $\operatorname{nir} S$ as the dominant gene for nitrite reductase as $\mathrm{NO}_{3}{ }^{-}$did not differ in WS3 among tree species (Fig. 5). Ribbons, et al. (2018) reported no significant differences in nirK abundance in soils beneath a suite of broadleaf species, but a significantly lower abundance of nirK in spruce soils relative to hardwood. Preliminary data (not shown) collected from an additional watershed that was planted to Norway spruce (WS 6) within the FEF is contradictory, as the spruce soils contained a significantly greater abundance of nirK and nosZ genes compared to both WS 3 and WS 7 hardwood soils measured here.

Kelly, et al. (2021) reported that tree species may mediate abundance of certain functional genes, with black cherry soils containing a relatively high nirK abundance compared to other tree species. This finding is contrary to our results, wherein black cherry soils had lower nirK abundance in both watersheds and nirK abundance in WS 3 soils beneath black cherry trees was very low and rarely detectable (Table 2). Other studies (Ribbons, et al. 2016) have indicated that nirK may be less species-dependent than nirS.

Within WS 3, nirK abundance was significantly lower in soils beneath AM-associated species relative to ECM species (Fig. 10). This is attributable to the strong influence of black cherry on nirK, as it was nearly non-detectable beneath black cherry trees. Relative nos $Z$ abundance did not differ by species or fungal association within the watersheds (Table 2). The nirK:nosZ ratio did not significantly differ by tree species (Table 2) which is supported by the Kelly et al. (2021) findings in that similar nirK:nosZ ratios were observed across tree species. A higher ratio of nirK:nos $Z$ has been indicated to be a potential indicator of higher $\mathrm{N}_{2} \mathrm{O}$ production, as $\mathrm{N}_{2} \mathrm{O}$ production was statistically similar across species in the individual watersheds this is reflective of the similar nirK:nos $Z$ ratios among species. As discussed previously, the nirK:nos $Z$ ratio was higher in WS 3 but $\mathrm{N}_{2} \mathrm{O}$ production did not differ indicating nirK:nos $Z$ is not indicative of $\mathrm{N}_{2} \mathrm{O}$ production. 
There was no significant difference in gene abundance of nirK, nos Z, or nirK:nos $Z$ associated with tree species in this present study, thus our hypothesis that gene abundance would be influenced by tree species was not supported. Although, $\operatorname{nirK}$ abundance is lower in soils beneath AM-associated species in WS 3 (Fig 10), there were no significant differences between the $\mathrm{NH}_{4}^{+}, \mathrm{N}_{2} \mathrm{O}$, or $\mathrm{NO}_{3}{ }^{-}$ pools in WS 3 associated with fungal association. It is possible that the diversity of neighboring trees and understory vegetation may have masked any species level influences on the soil microbial community. Several studies (e.g., Yang, et al. 2018) have shown that understory vegetation can strongly affect the soil microbial biomass and extracellular enzyme activities, which may make differentiation of the influence by dominant tree species difficult. Tree species influence on soil microbial genetic composition and metabolic function is still poorly understood (Ribbons, et al. 2018; Dukunde, et al. 2019; Kelly, et al. 2021).

\subsection{Acidification Influence on Gene Abundance}

The positive correlation of soil $\mathrm{pH}$ with gene abundance (Fig.11) supports our hypothesis that WS 3 would exhibit decreased nos $Z$ abundance in comparison to WS 7. We identified a significant difference in functional gene abundance at the watershed scale (Table 2). Abundance of nirK and nos $Z$ was significantly lower under $\mathrm{N}$ fertilization in WS 3 (Fig. 9). As previously discussed, $\mathrm{N}$ fertilization leads to soil acidification through base cation leaching and creation of $\mathrm{H}^{+}$protons. Soil $\mathrm{pH}$ has been shown to be a major driver of bacterial biodiversity as acidic environments influence species tolerant of high acidity (low pH) (Palmer and Horn 2012) and inhibit bacterial growth (Liu, Frostegard, \& Bakken 2014) due to nutrient limitations. Soil acidity is a particularly strong driver of microbial diversity as homogeneity is an effect of low pH (Deforest, et al. 2012; Zhang, Chen \& Ruan, 2018; Shetty \& Prakash, 2020).

Our data show that both nirK and nosZ relative abundance are significantly lower in WS 3 (Fig. 9), and this finding is correlated to lower soil $\mathrm{pH}$ (Fig. 11); as soil $\mathrm{pH}$ increases, nirK and $\operatorname{nos} Z$ abundances increases. This is congruent with findings from previous studies (e.g. Liu, Frostegard, \& Bakken 2014; Xiao, et al. 2019; Aamar, et al. 2020) that demonstrate that acidic soils reduce functionality and abundance of nirK and nos $Z$ genes. Reductions in nirK abundance in WS 3 may be due to acidic soils influencing abundance of nirS, as organisms containing nirS are more acid tolerant and nirK is not found in organisms containing nirS (Palmer \& Horn, 2012). Due to the relatively acidic nature of soil from both watersheds, the microbial community functionality may 
be similar even though the relative abundances are distinct, resulting in similar the $\mathrm{N}$ transformation rates measured here (Fig 12-15) (Liu, Frostegard, \& Bakken 2014).

\subsection{Limitations of the study and future directions}

Our study design attempted to capture spatial variability by creating homogenized, composite samples from 5 points under each tree sampled. Due to the relatively small sample size $(n=32)$, however, the full microbial community and $\mathrm{N}$ transformations may not have been sufficiently examined. As previously stated, understory variability may have a masking effect on tree species influence on $\mathrm{N}$ transformations and gene abundance. Decoupling tree species impact and understory impact is difficult in field-based experiments with diverse understories. In order to fully address the question of tree species impact on gene abundance, a greenhouse-based study or experimental vegetation plantings could isolate the specific influence of tree species (and associated fungal effects). Monodominant plot-based field studies have been able to isolate fungal associated effects (Brzostek, et al. 2015; Midgley \& Sims 2020).

We were unable to generate amplicons necessary to quantify amoA and nirS; qPCR is limited by amplicon size and large fragments $(b p>150)$ reduce the accuracy and specificity of the reaction (Smith \& Osborn 2009). Thus, we were not able to fully capture the abundance of key genes linked to denitrification and nitrification within the watersheds or for soils underneath specific species. qPCR may not capture all genes associated with $\mathrm{N}_{2} \mathrm{O}$ reductase and nitrite reductase. For example, nos $Z$ is known to have a canonical type and a divergent type, and the commonly used nos $Z$ primer sets are not usually capturing the full nosZ diversity (Sanford., et al. 2012; Li., et al. 2017), as the primer sets used for nos $Z$ were designed to capture canonical nos $Z$. Full metagenomic sequencing of these soils may help in quantification of the functional genes of interest.

Additionally, inclusion of measures of enzyme activities to link to gene abundance would allow for a broader picture as well as aid in support of using gene abundance as a proxy for microbial $\mathrm{N}$ transformations, as, no relationship between $\mathrm{N}$ transformations and gene abundance was observed.

\section{Conclusions}

Our results show that the 30 years of forest fertilization with $\left(\mathrm{NH}_{4}\right)_{2} \mathrm{SO}_{4}$ has altered soil microbial gene abundance, as fertilized soils exhibit decreased nir $S$ and nos $Z$ gene abundance. This shift in gene abundance is correlated with lower soil $\mathrm{pH}$. While there may be other drivers of gene 
abundance, acidity appears to be the main driver in this study. Measured $\mathrm{N}$ pools were not observed to be correlated to gene abundance in this study. Tree species influences on the soil parameters suggest that black cherry is a unique driver of $\mathrm{N}$ cycling. Gene abundance of nirK and nos $Z$ were not observed to be impacted by tree species in this study. Soils beneath AM-associated species in WS 3 demonstrated reduced nirK abundance, indicating mycorrhizal association may alter microbial genetic composition. $\mathrm{N}$ management is important for ecosystem health, as the $\mathrm{N}$ cycle is primarily microbially driven, it is pertinent to understand the driving forces behind $\mathrm{N}$ pollutant production through bacterial metabolic transformations encoded by $\mathrm{N}$ cycling genes. While the presence of functional genes does not necessarily indicate an active community, it can provide insights into the complexity of biogeochemical cycles such as the $\mathrm{N}$ cycle. 


\section{Tables}

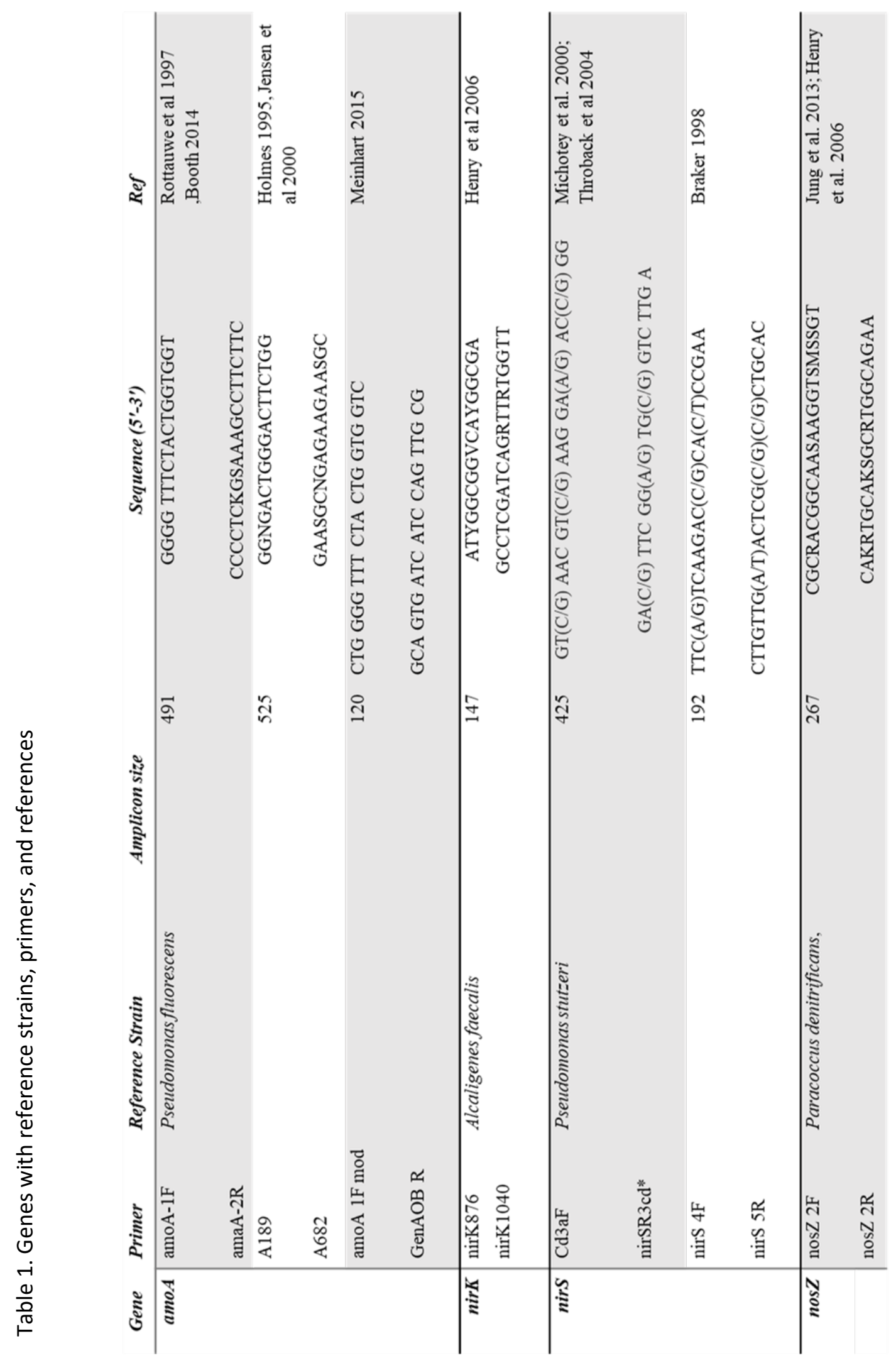




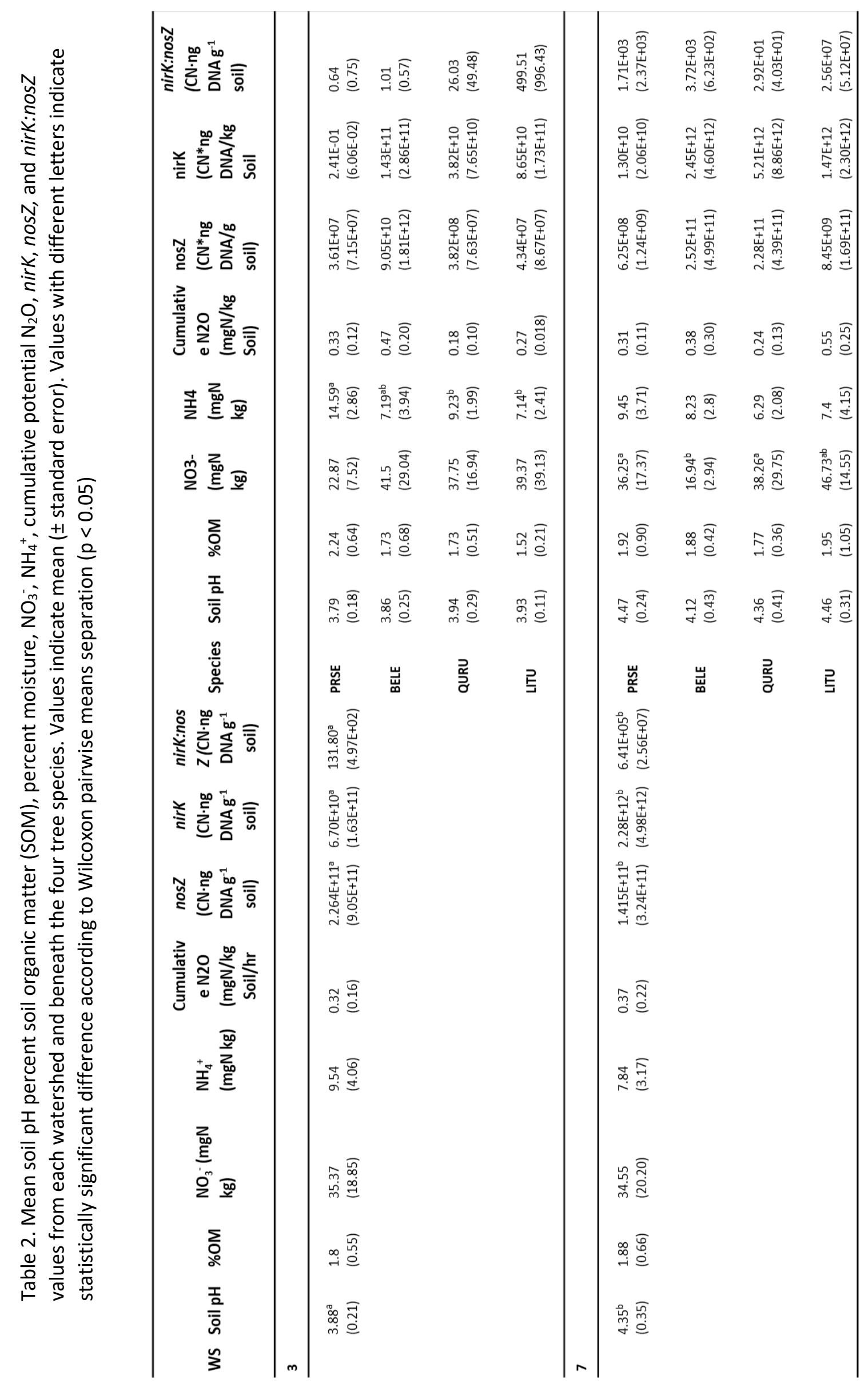


Table 3. Primer sets for four functional genes with annealing temp and whether amplification was successful with use of standard PCR.

*Indicate touchdown PCR was run

\begin{tabular}{|c|c|c|c|}
\hline Gene & Primer set & Annealing & Amplification \\
\hline \multicolumn{4}{|l|}{ amoA } \\
\hline & $\begin{array}{l}\text { amoA-1F } \\
\text { amoA-2R }\end{array}$ & 54 & - \\
\hline & A189 & $54 *$ & + \\
\hline & $\begin{array}{l}\text { A682 } \\
\text { GenAOB F }\end{array}$ & & \\
\hline & GenAOB R & $57 *$ & - \\
\hline & $\begin{array}{l}\text { GenAOB } 1 F \\
\bmod \end{array}$ & $54^{*}$ & - \\
\hline \multicolumn{4}{|l|}{$\overline{n i r K}$} \\
\hline & $\begin{array}{l}\text { nirK876 } \\
\text { nirK1040 }\end{array}$ & 57 & + \\
\hline \multicolumn{4}{|l|}{ nirS } \\
\hline & $\begin{array}{l}\text { Cd3af } \\
\text { nirSR3cd* } \\
\text { nirS 4f } \\
\text { nirS5R }\end{array}$ & $51^{*}$ & - \\
\hline \multicolumn{4}{|l|}{$\overline{n o s} Z$} \\
\hline & $\begin{array}{l}\operatorname{nos} Z 2 F \\
\operatorname{nos} Z 2 R\end{array}$ & 52 & + \\
\hline
\end{tabular}




\section{Figures}

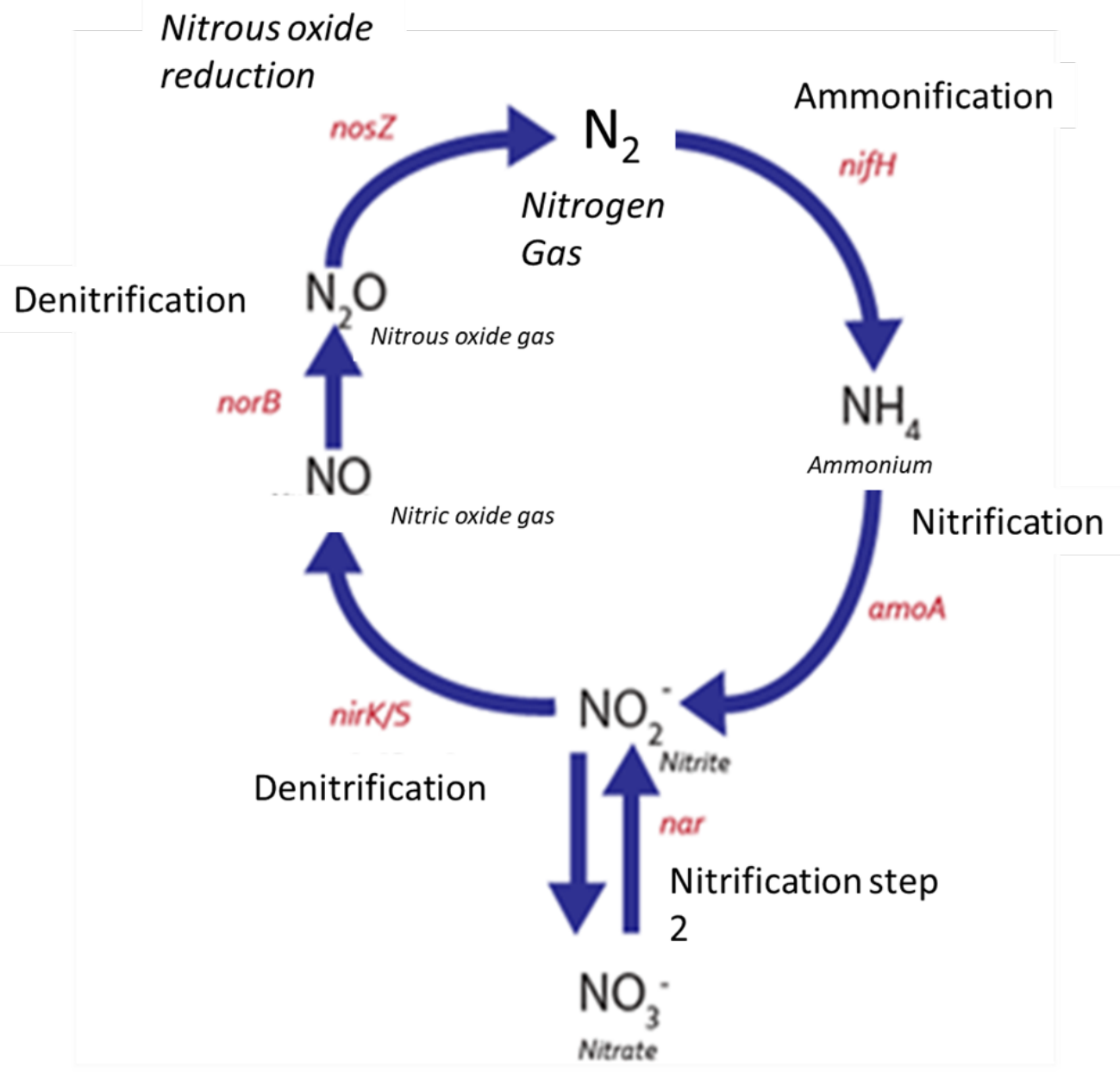

Figure 1. The nitrogen cycle with all steps and products indicated with associated functional gene in red. 


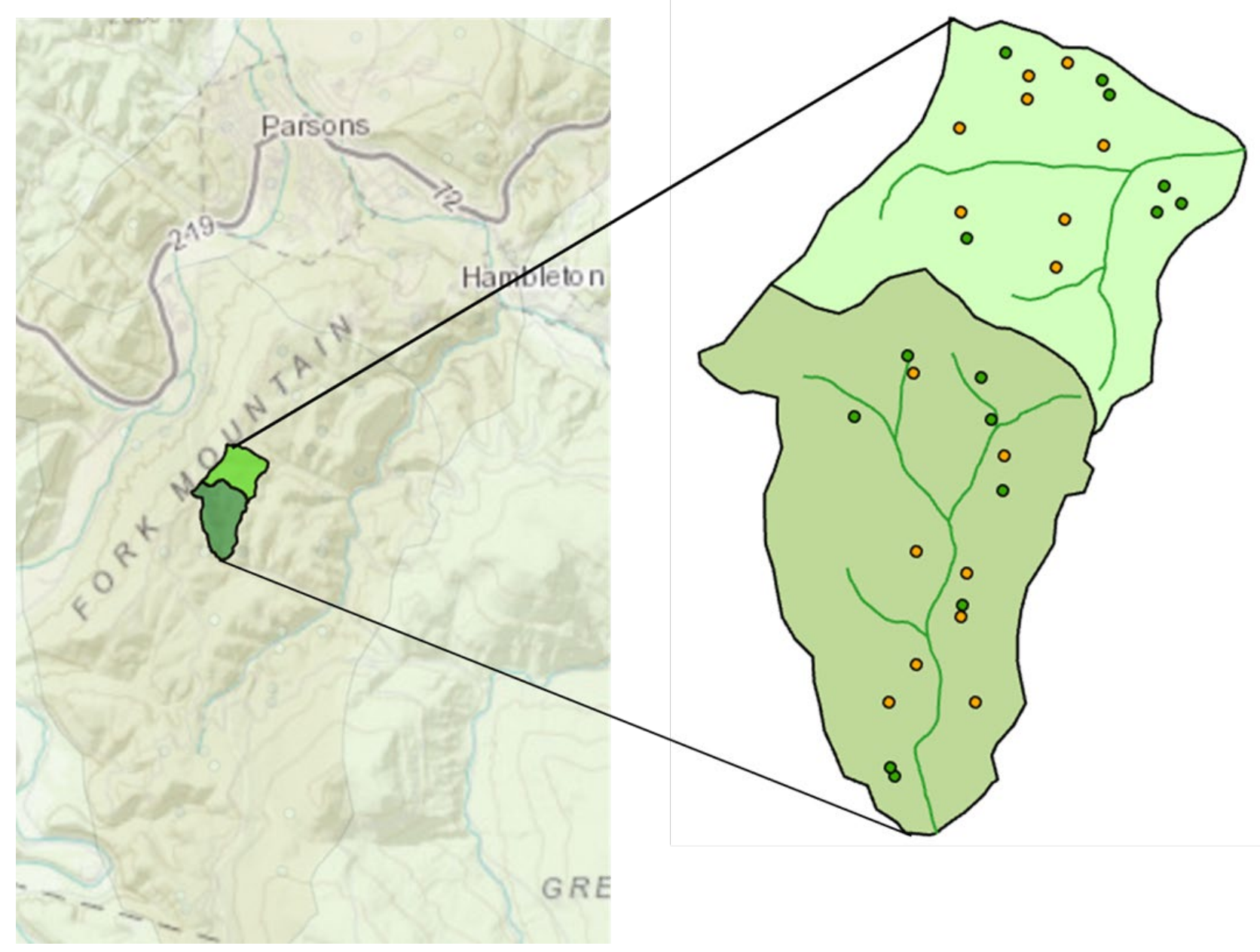

Figure 2. A map of WS3 and WS7 in the FEF. Watershed 3 is dark green and watershed 7 is light green, AM trees are orange points and ECM trees are green. 

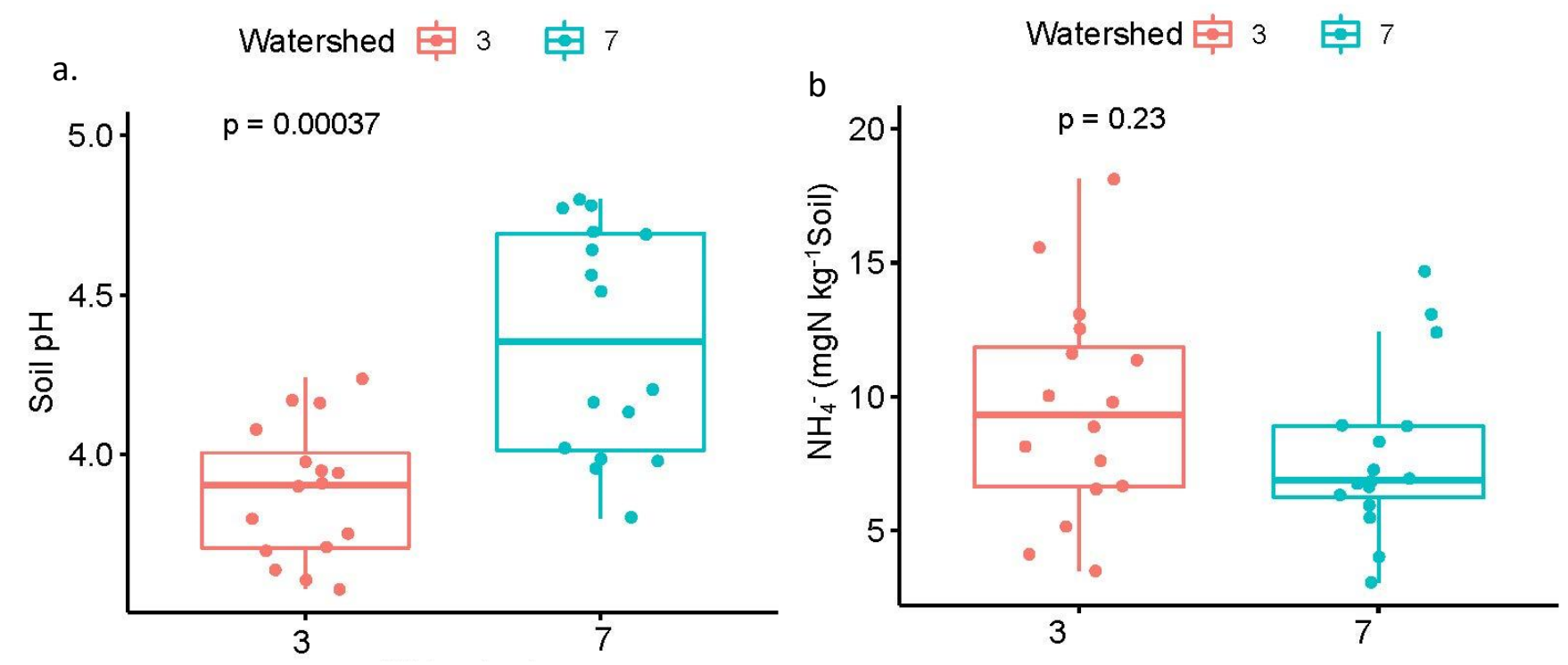

c.

\section{Watershed 3 审 7}

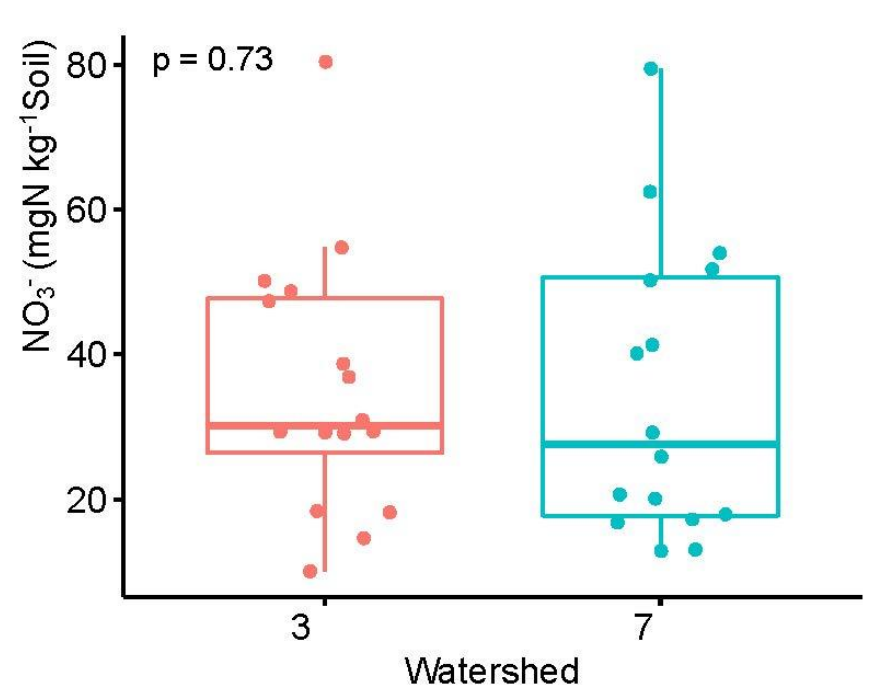

d.
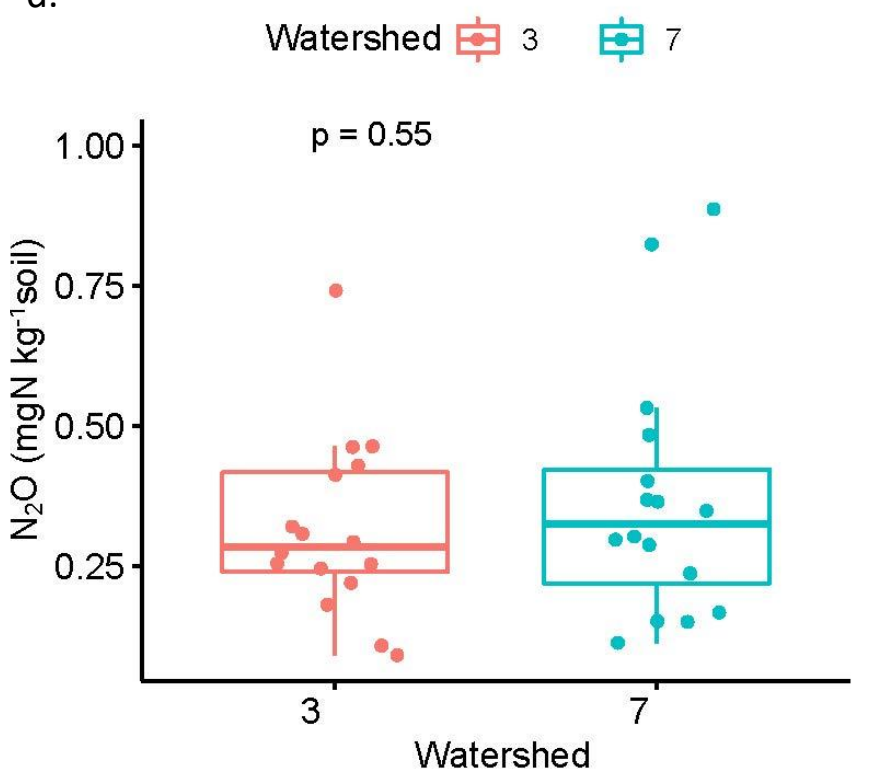

Figure 3. Soil property differences between watersheds. Panel a is showing soil $\mathrm{pH}$ between watersheds, WS3 has significantly lower $\mathrm{pH}$ than WS7. Panels b-d show $\mathrm{N}$ concentrations in different forms which did not vary significantly between watersheds. Boxplots with different lower-case letters indicate significantly different means according to Wilcoxon two sample test ( $p$ $<0.05$ ). 


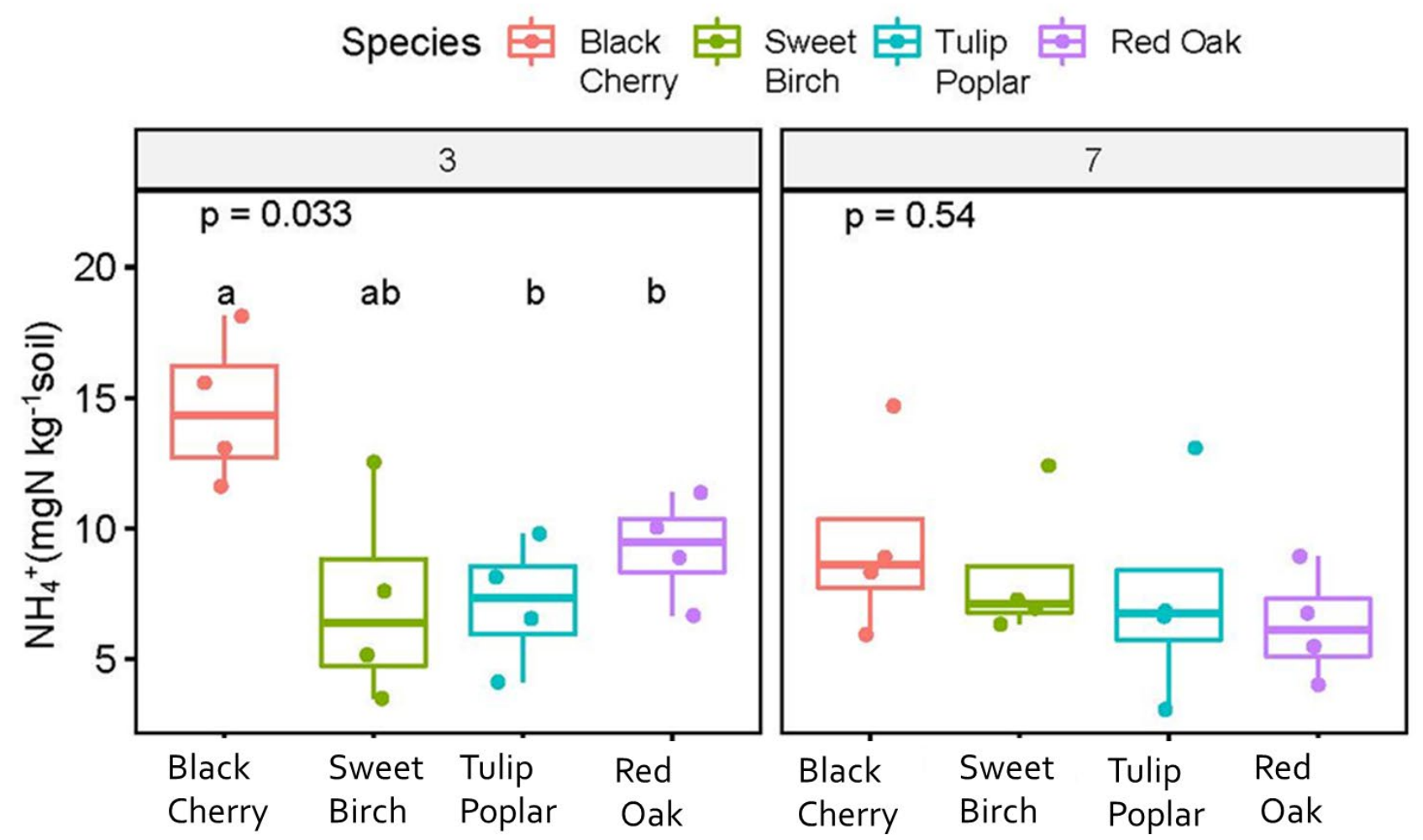

Figure 4. $\mathrm{NH}_{4}{ }^{+}$concentrations correlated to tree species split by watershed. For each species, boxplots with different letters within each watershed are significantly different according to pairwise Wilcox test $(p<0.05)$. 


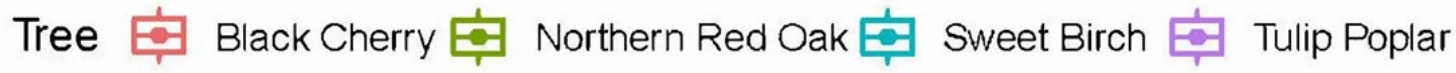
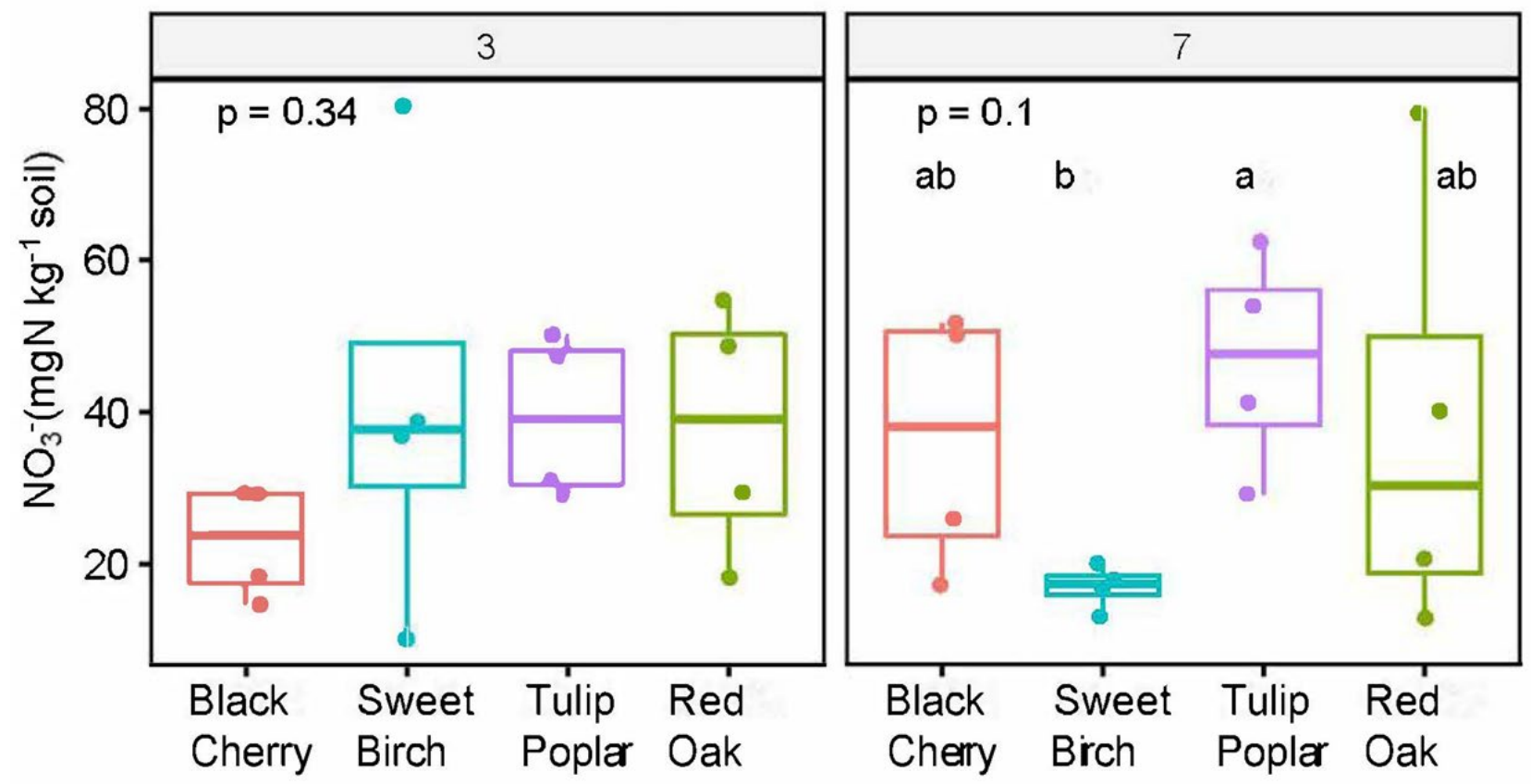

Figure 5. Soil $\mathrm{NO}_{3}{ }^{-}$concentrations in WS 3 and WS 7. For each species, boxplots with different letters within each watershed are significantly different according to pairwise Wilcox two sample test $(\mathrm{p}<0.05)$. 


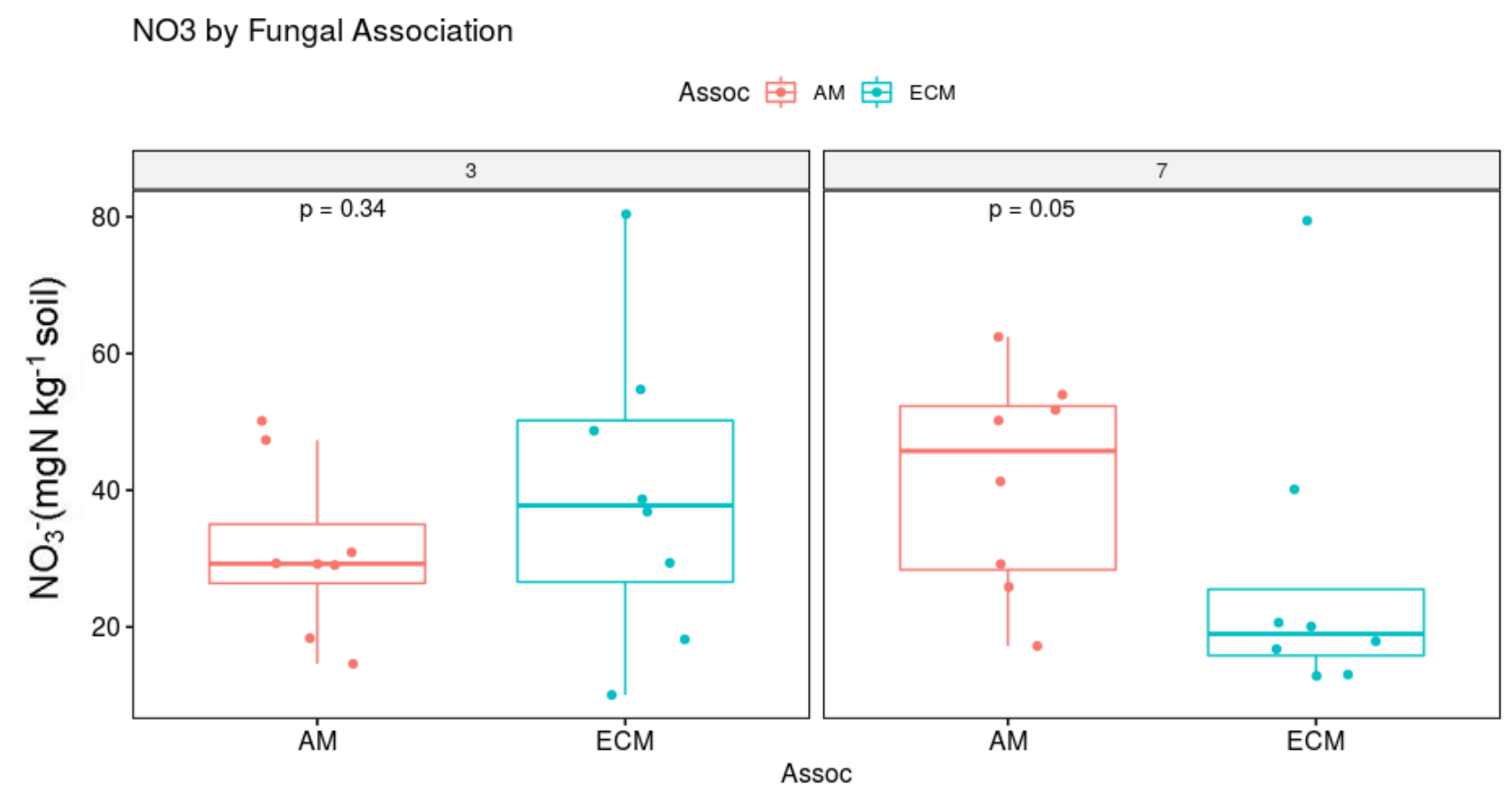

Figure 6. Soil $\mathrm{NO}_{3}{ }^{-}$concentrations in WS 3 and WS 7 by fungal association. For each watershed, boxplots with different letters within each watershed are significantly different according to pairwise Wilcoxon two sample test $(\mathrm{p}<0.05)$. 

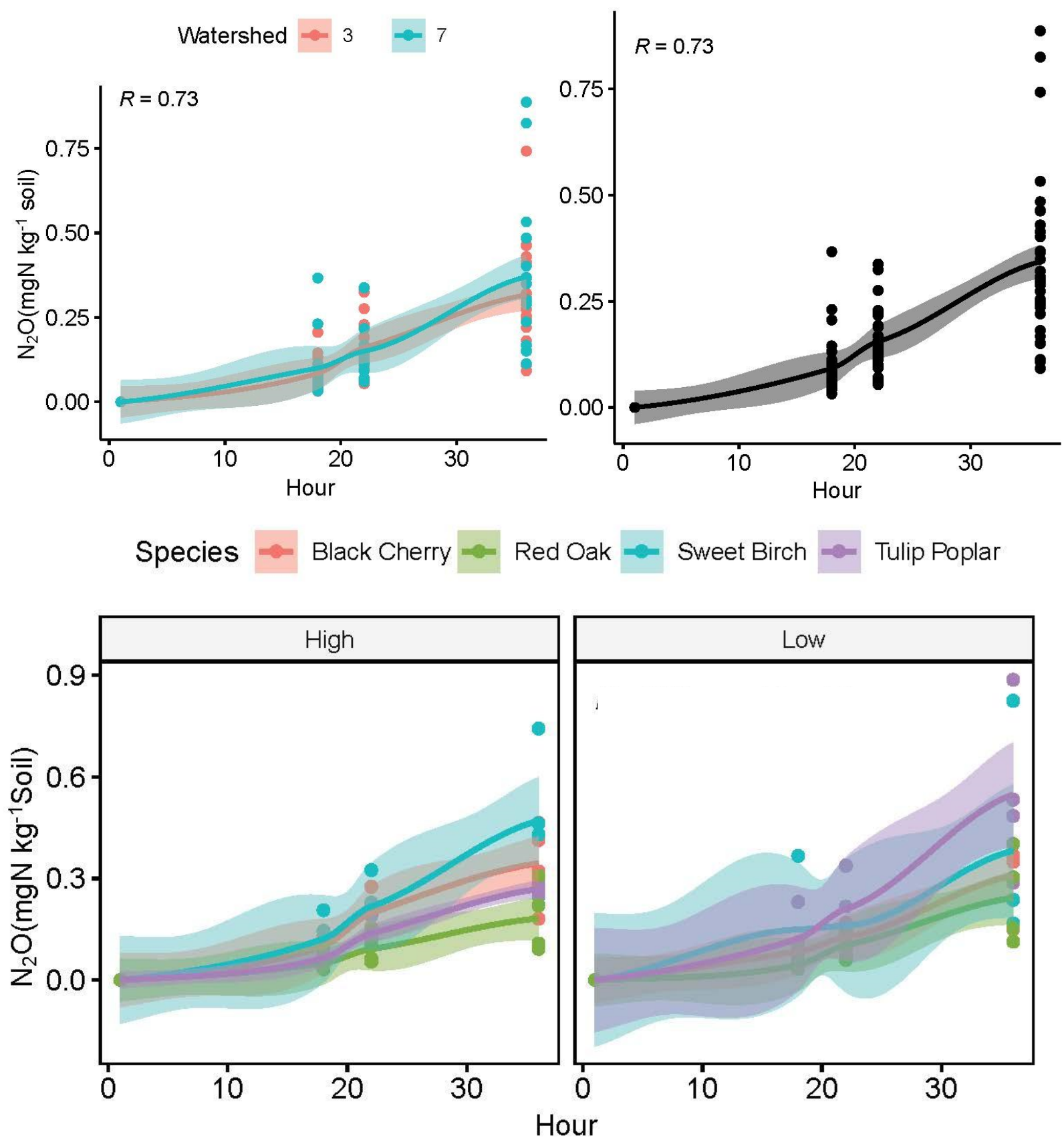

Figure 7. Potential $\mathrm{N}_{2} \mathrm{O}$ production over the 36-hour incubation time with standard error: (a) Potential $\mathrm{N}_{2} \mathrm{O}$ production by watershed. (b) Potential $\mathrm{N}_{2} \mathrm{O}$ production over a 36-hour incubation for all samples. (c) Potential $\mathrm{N}_{2} \mathrm{O}$ production in the high $\mathrm{N}$ watershed over the incubation period. (d) Potential $\mathrm{N}_{2} \mathrm{O}$ production in the reference watershed over the incubation period. $\mathrm{R}$ values indicates a relationship with $\mathrm{N}_{2} \mathrm{O}$ production over time. Colors delineate tree species. 

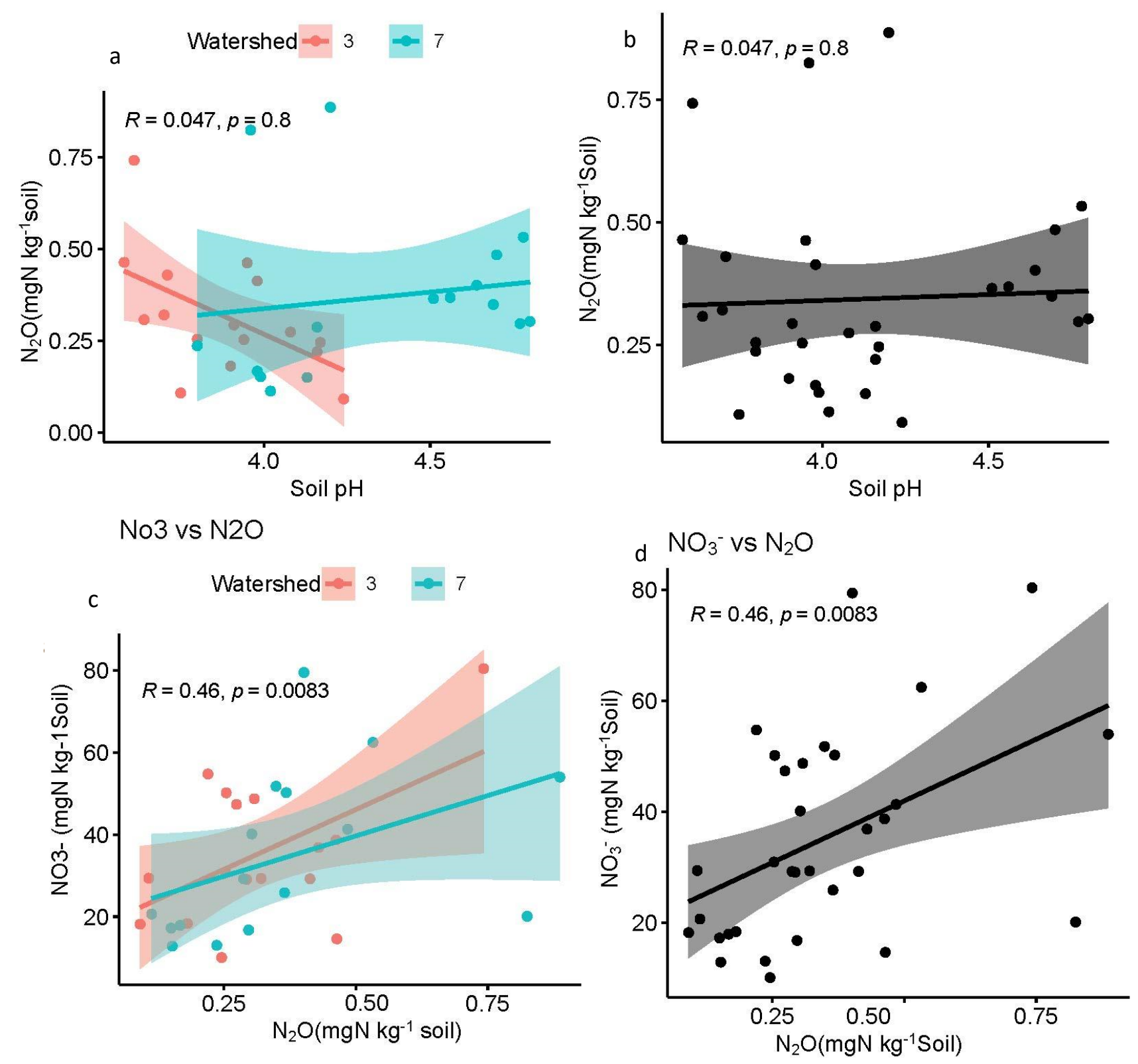

Figure 8. The relationship of cumulative potential $\mathrm{N}_{2} \mathrm{O}$ to soil $\mathrm{pH}$ and $\mathrm{NO}_{3}{ }^{-}$in (a) relationship between soil $\mathrm{pH}$ and potential end point $\mathrm{N}_{2} \mathrm{O}$; (b) relationship of end point $\mathrm{N}_{2} \mathrm{O}$ to soil $\mathrm{pH}$ for all samples demonstrating no significant trend; (c) relationship of $\mathrm{NO}_{3}{ }^{-}$ to potential $\mathrm{N}_{2} \mathrm{O}$ production in WS 3 (red) and WS 7 (blue); and (d) relationship of $\mathrm{NO}_{3}{ }^{-}$ to potential $\mathrm{N}_{2} \mathrm{O}$ production for all samples. 

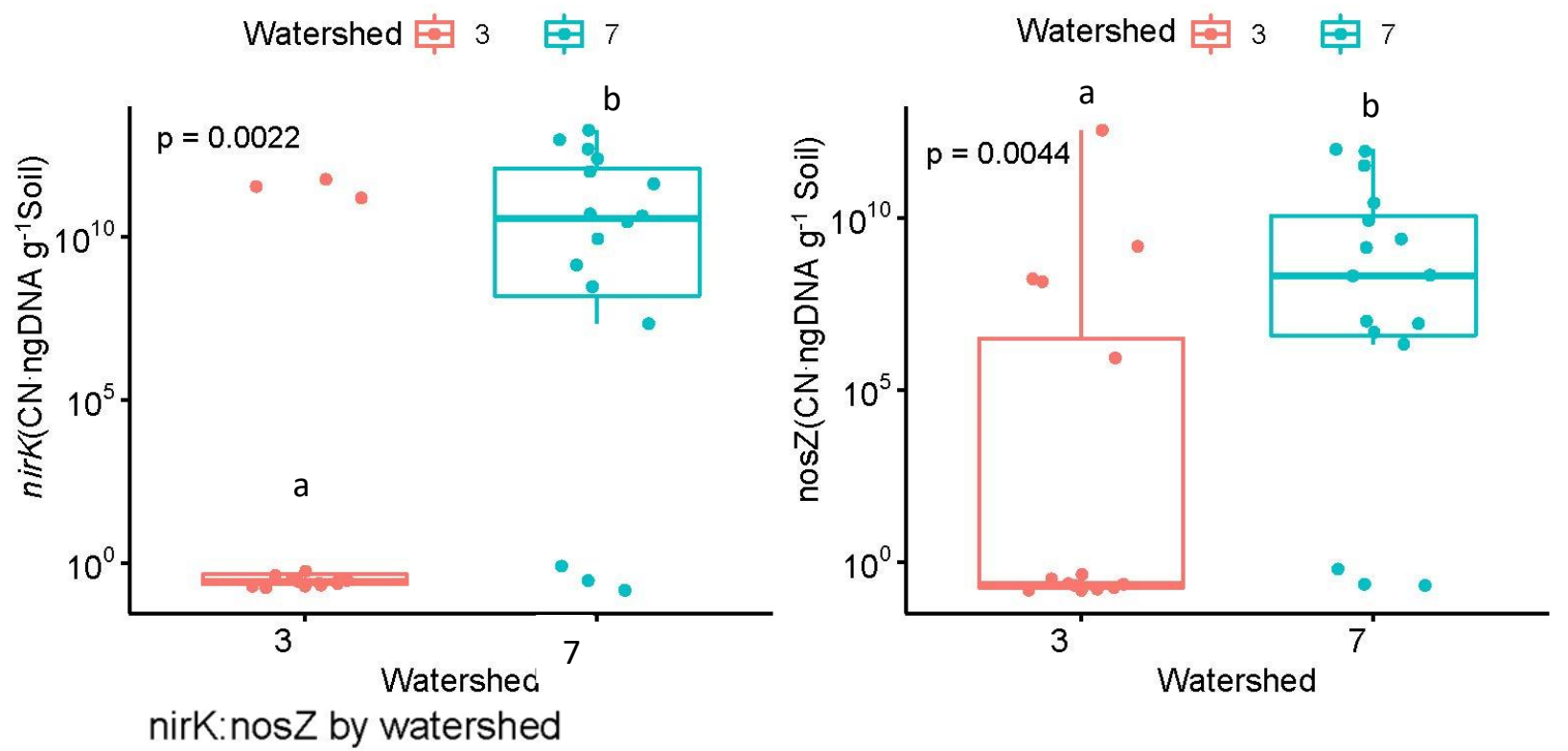

Watershed 庐 3 庐 7

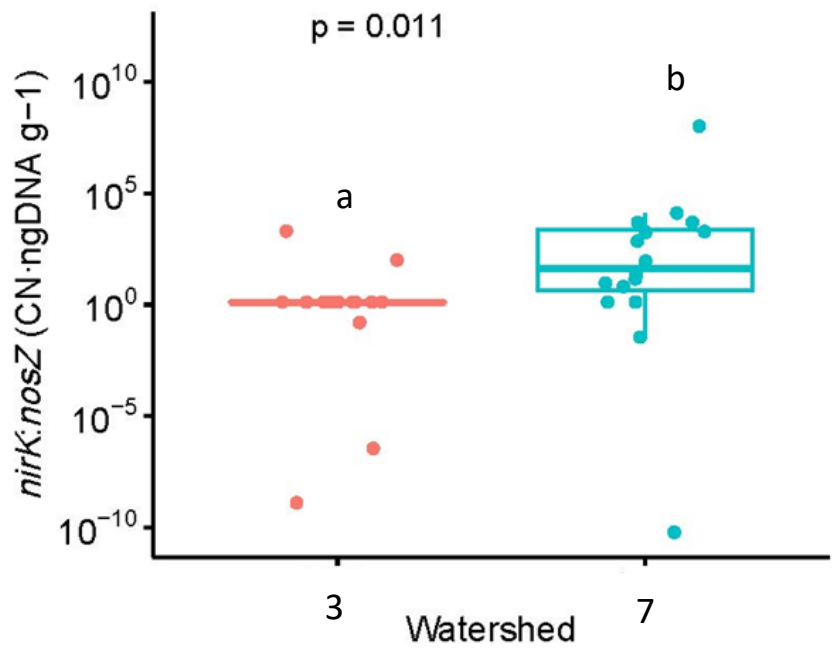

Figure 9. Relative abundance of nirK,nos Z and nirK:nos $Z$ between watersheds. Boxplots with different lower-case letters indicate significantly different means according to Wilcoxon two sample test $(\mathrm{p}<0.05)$. 

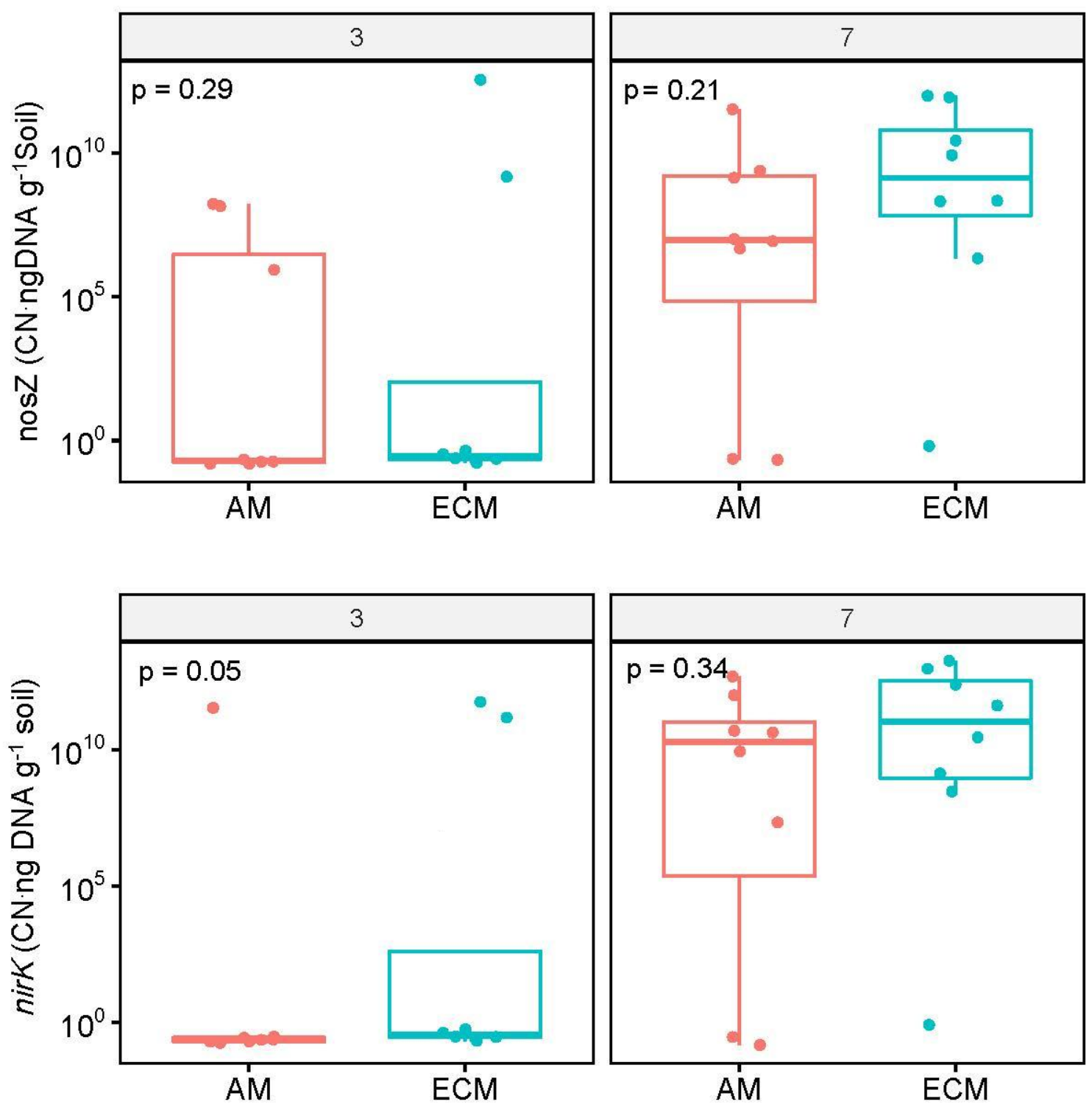

Figure 10. Relative abundance of nirK and nos $Z$ by fungal association. Boxplots with different lower-case letters are significantly different according to Wilcoxon two sample test $(\mathrm{p}<0.05)$. 

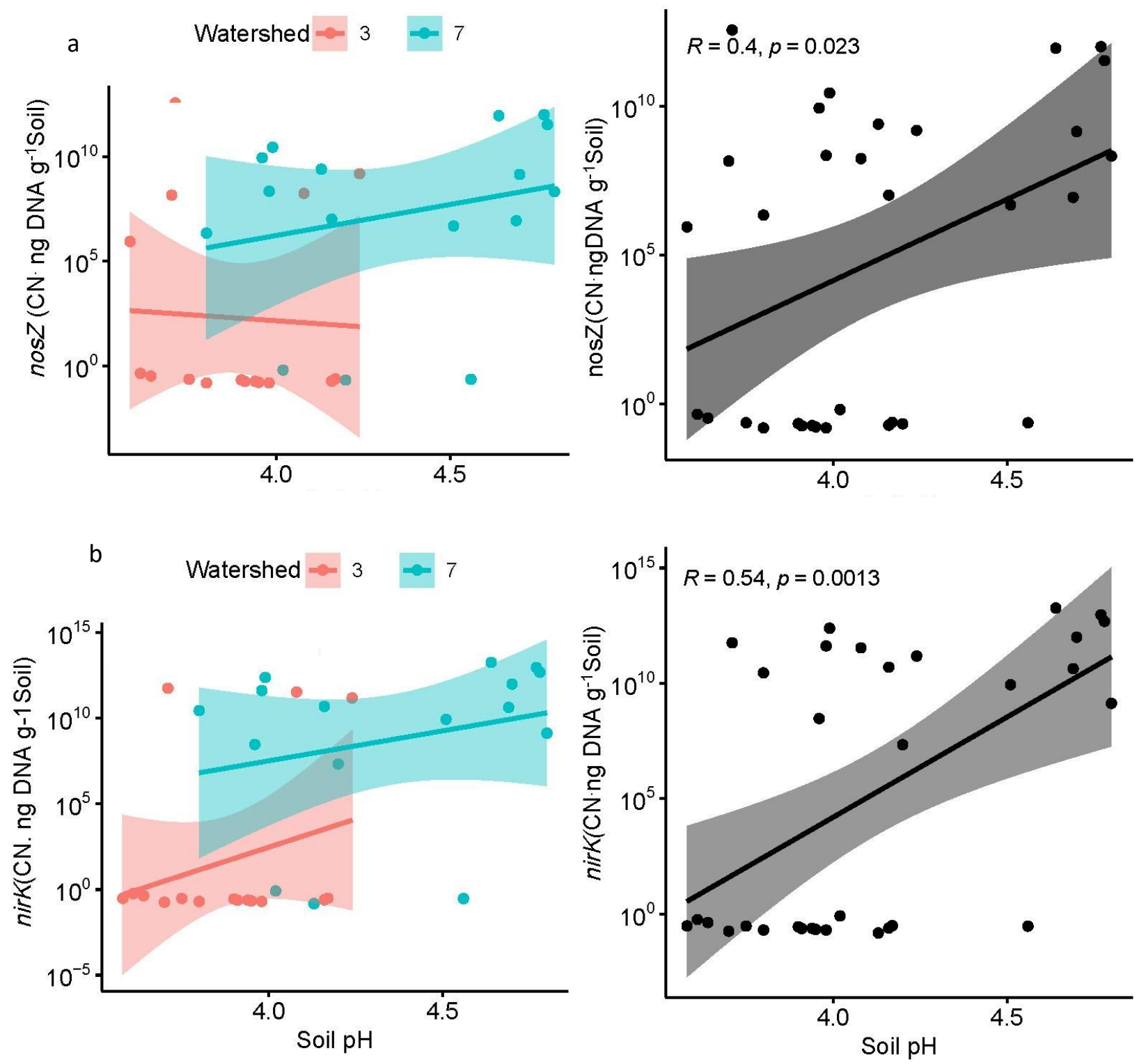

Figure 11. Relationship between gene abundance and soil $\mathrm{pH}$. (a) nos $\mathrm{Z}$ abundance in relation to soil $\mathrm{pH}$. (b) nirK abundance in relation to soil $\mathrm{pH}$. $\mathrm{R}$ and $\mathrm{p}$-values are denoted for each panel for all data across watersheds. 

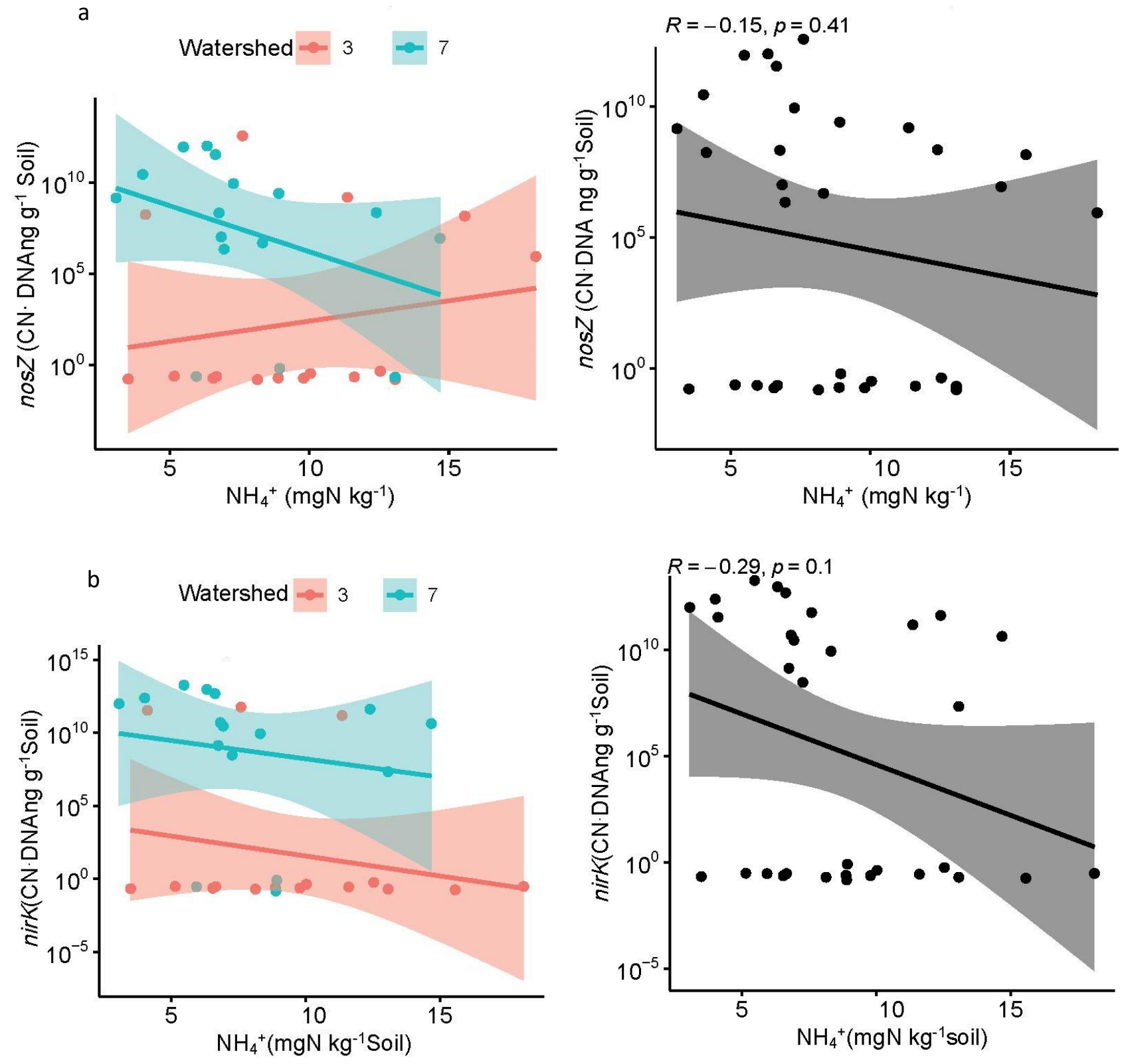

Figure 12. Relationship between gene abundance and $\mathrm{NH}_{4}{ }^{+}$. A. nosZ abundance in relation to $\mathrm{NH}_{4}{ }^{+}$. B. nirK abundance in relation to $\mathrm{NH}_{4}{ }^{+}$. $\mathrm{R}$ and $\mathrm{p}$-values are denoted for each panel for all data across watersheds 


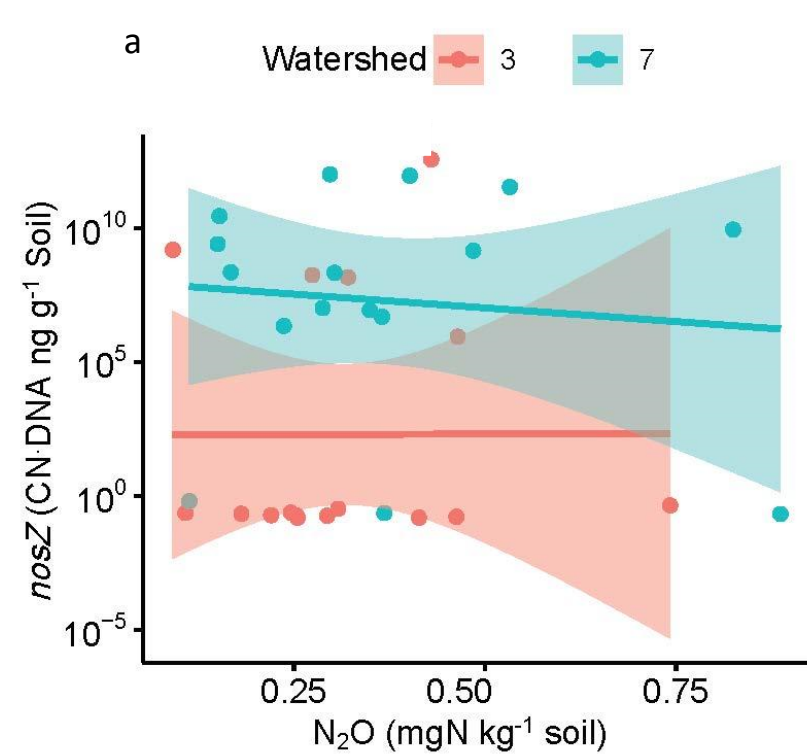

nirK abundance vs $\mathrm{N} 2 \mathrm{O}$

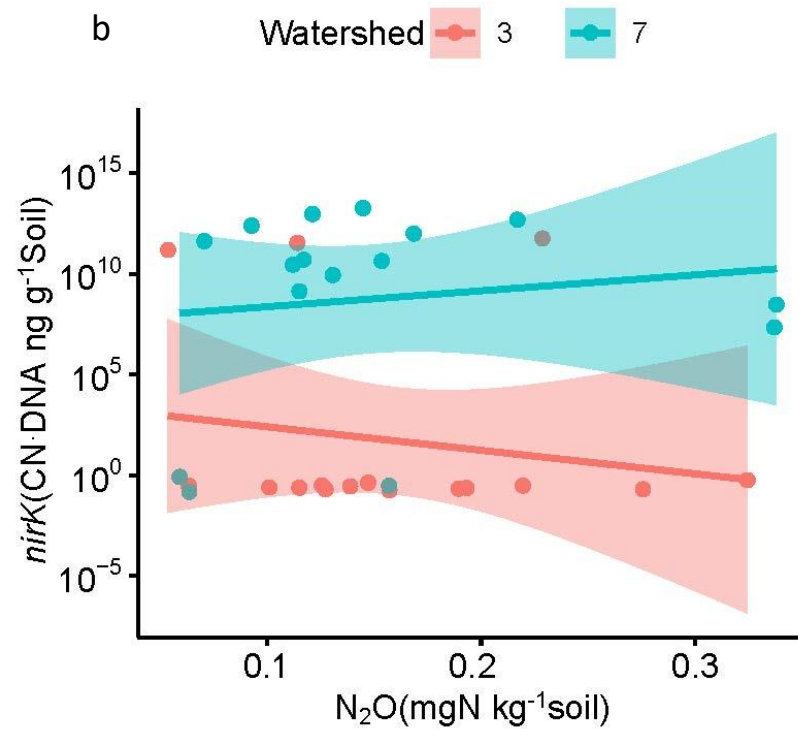

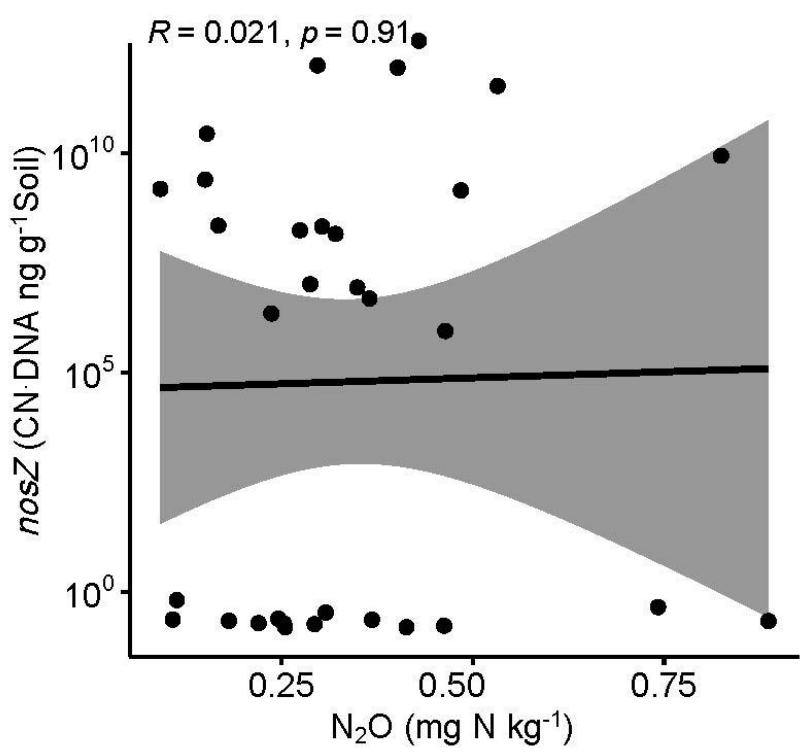

nirK abundance vs N2O

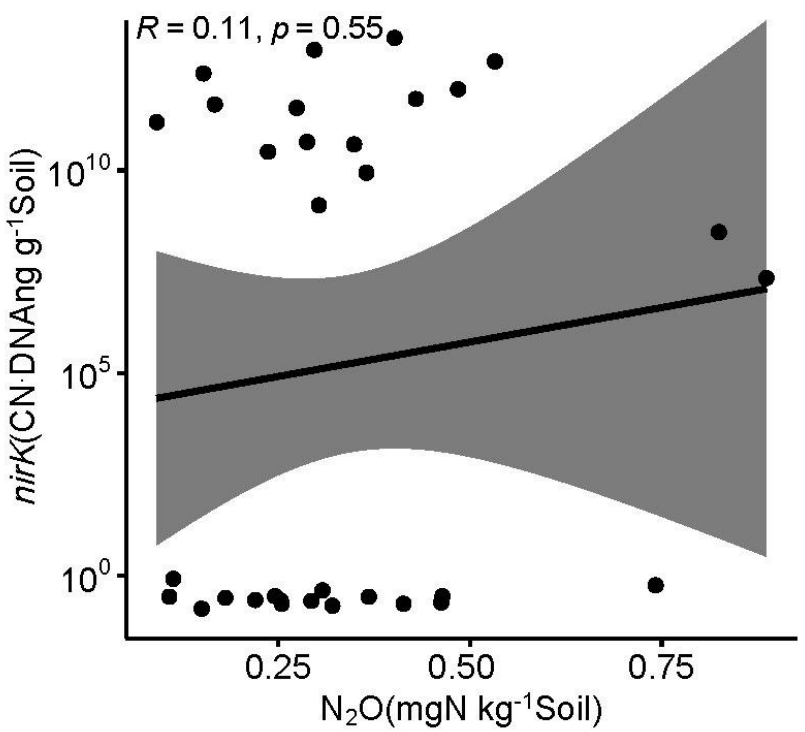

Figure 13. Relationship between gene abundance and $\mathrm{N}_{2} \mathrm{O}$. (a) nos $Z$ abundance in relation to $\mathrm{N}_{2} \mathrm{O}$. (b) nirK abundance in relation to $\mathrm{N}_{2} \mathrm{O}$. $\mathrm{R}$ and $\mathrm{p}$-values are denoted for each panel for all data across watersheds. 

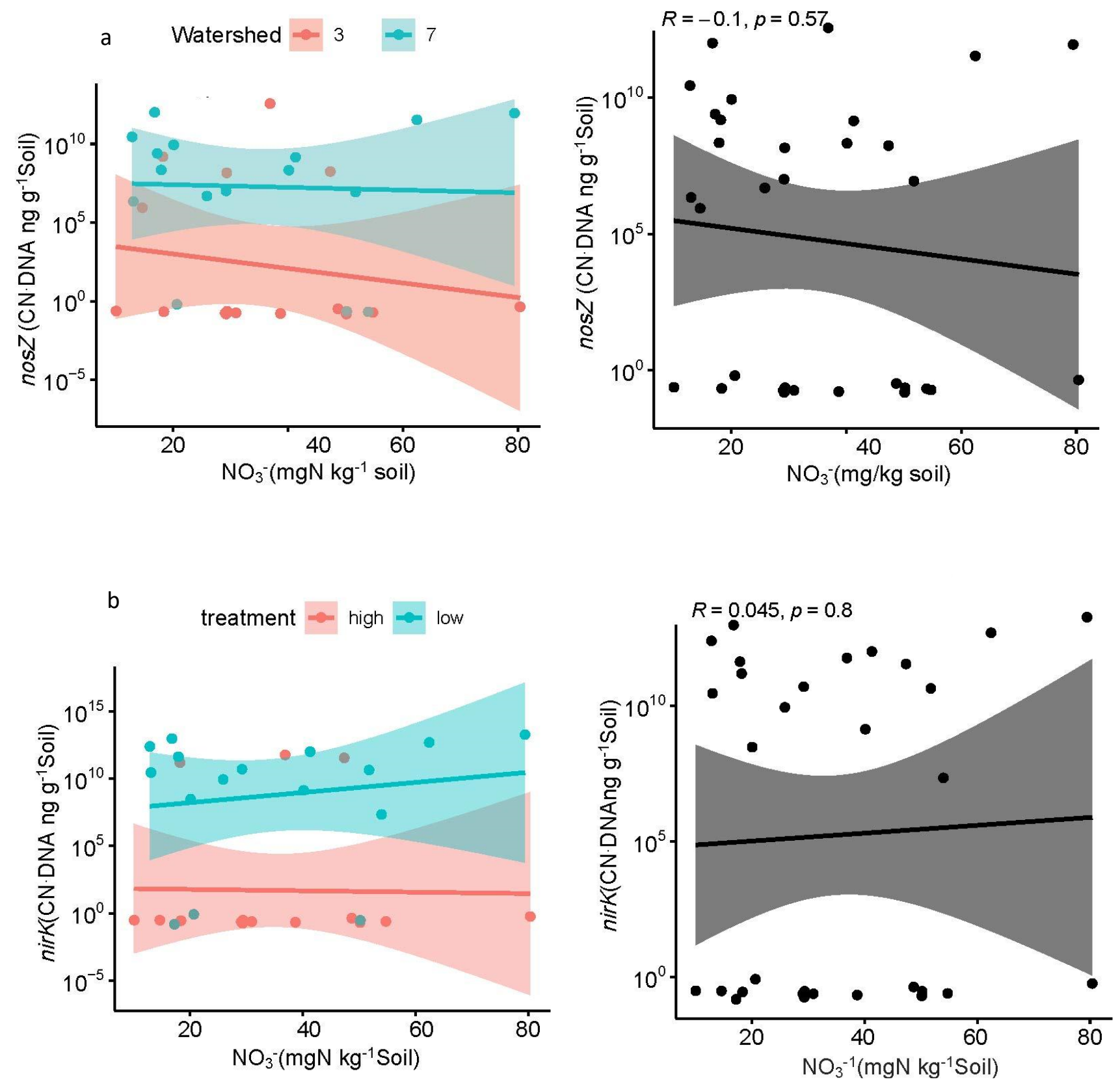

Figure 14. Relationship between gene abundance and $\mathrm{NO}_{3}{ }^{-}$. (a) nos $\mathrm{Z}$ abundance in relation to $\mathrm{NO}_{3}{ }^{-}$. (b) nirK abundance in relation to $\mathrm{NO}_{3}{ }^{-}$. $\mathrm{R}$ and $\mathrm{p}$-values are denoted for each panel for all data across watersheds 

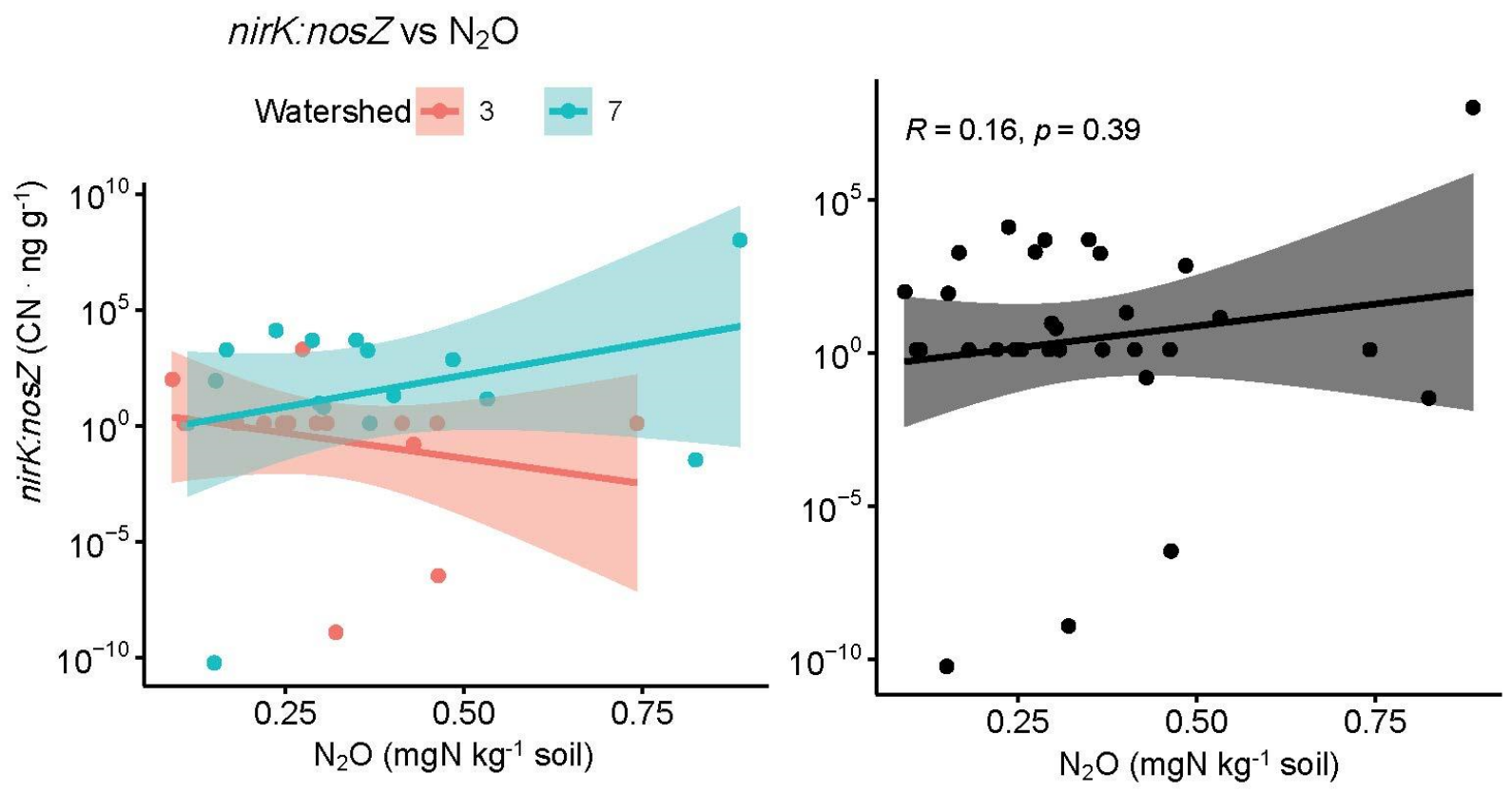

Figure 15. Ratio of nirK to nos $Z$ in relation to cumulative potential $\mathrm{N}_{2} \mathrm{O}$ by watershed and overall ratio of nirK to nos $Z$ in relation to cumulative potential $\mathrm{N}_{2} \mathrm{O}$. R and $\mathrm{p}$-values are denoted for each panel for all data across watersheds 


\section{References}

Aamar, M., Shaaban, M., Umair Hassan, M., Guoqin, H., Ying, L., Ying, T. H., . . Peng, Z. (2020). Biochar mitigates the $\mathrm{N} 2 \mathrm{O}$ emissions from acidic soil by increasing the nosZ and nirK gene abundance and soil $\mathrm{pH}$. Journal of Environmental Management,

Aas, W., Mortier, V., Bowersox, E., Faluvegi, C.G., Fagerli, H., et al. (2019) Global and regional trends of atmospheric sulfur. Science Rep., 953

Attard, E., Recous, S., Chabbi, A., De Berranger, C., Guillaumaud, N., Labreuche, J., ... Le Roux, X. (2010). Soil environmental conditions rather than denitrifier abundance and diversity drive potential denitrification after changes in land uses. Global Change Biology, 1975 - 1989.

Aber JD, McDowell W., Nadelhoffer K., Magill A., Berntson G., Kamakea M., McNulty S., Currie, W., Rustad L., Fernandez I. (1998) Nitrogen saturation in temperate forest ecosystems hypotheses revisited. Bioscience 48(11):921-934

Aber, J. D., Magill, A., Mcnulty, S. G., Boone, R. D., Nadelhoffer, K. J., Downs, M., Hallett, R. (1995). Forest biogeochemistry and primary production altered by nitrogen saturation. Water, Air, and Soil Pollution, 1665-1670.

Aber, J. D., Nadelhoffer Knute J., Steudler P.1, Melillo J.M. (1989) Nitrogen Saturation in northern forest ecosystems: excess nitrogen from fossil fuel combustion may stress the biosphere. BioScience, 378-386

Adams, M.B., Kelly, C.N., Kabrick, J., Schuler, J. (2019). Temperate forests and soils. In Global Change and Forest Soils (pp. 83-107).

Adams, M. B., Kochenderfer, J. N., Edwards, P. J. (2007). The Fernow Watershed Acidification Study: ecosystem acidification, nitrogen saturation and base cation leaching. Water, Air, and Soil Pollution, 267273.

Adams, M.B., DeWalle, D.R., Hom.J.L. (2006). The Fernow Watershed Acidification Study. Enivronmental Pollution. Springer. Dordechet, Netherlands.

Adams, M. B., Loughry, L., Plaugher, L. (2003). Experimental Forests and Ranges of the USDA Forest Service. General Technical Reports NE 321 Revised.

Adams, M.B., \& Angradi, T. (1996). Decomposition and nutrient dynamics of hardwood leaf litter in the Fernow Whole-Watershed Acidification Experiment. Forest Ecology and Management 61-69.

Backman, J., \& Klemedtsson, A. (2003). Increased Nitrification in Acid Coniferous Forest Soil Due to High Nitrogen Depostion and Liming. Scandinavian Journal of Forest Research, 514 - 524.

Barta, J., Melichova, T., Vanek, D., Picek, T., Santruckova, H. (2010). Effect of pH and dissolved organic matter on the abundance of nirK and nirS denitrifiers in Spruce forest soil. Biogeochemistry, 123-132.

Bates, J., Brophy, N., Harfoot., M., Webb, J. (2008). Agriculture: methane and nitrous oxide. The Energy Journal. 1-62 
Braker G, Fesefeldt A, Witzel KP. (1998). Development of PCR primer systems for amplification of nitrite reductase genes (nirK and nirS) to detect denitrifying bacteria in environmental samples. Applied Environmental Microbiology. 3769-75.

Brzostek, E., Dragoni, D., Brown, Z., Phillips, R. (2015). Mycorrhizal type determines the magnitude and direction of root-induced changes in decomposition in a temperate forest. New Phytologist, 1274- 1282.

Brzostek, E., \& Finzi, A. (2011). Substrate supply, fine roots, and temperature control proteolytic enzyme activity in temperate forest soils. Ecology, 892 - 902.

Burnham, M., Cmming, J., Adams, M. B., Peterjohn, W. (2017). Soluble soil aluminum alters the relative uptake of mineral nitrogen forms by six mature temperate broadleaf tree species: possible implications for watershed nitrate retention. Oecologia, 327-337.

Burns, D.A., Bhatt, G., Linker, L.C., Bash, J.O., Capel, P.D., Shenk, G.W., (2021). Atmospheric nitrogen deposition in the Chesapeake Bay watershed: A history of change, Atmospheric Environment, 118-277,

Butterbach-Bahl, K., Baggs, E. M., Dannenmann, M., Kiese, R., Zechmeister-Boltenstern, S. (2013). Nitrous oxide emissions from soils: how well do we understand the processes and their controls? Philosophical transactions of the Royal Society of London. Series B, Biological sciences, 368

Carrara, J. E., Walter, C., Hawkins, J., Peterjohn, W., Averill, C., Brzostek, E. (2018). Interactions among plants, bacteria, and fungi reduce extracellular enzyme activities under long-term N fertilization. Global Change Biology, 2721-2734.

Castro MS, Steudler PA, Melillo JM, Aber JD, Millham S. (1992). Exchange of $\mathrm{N}_{2} \mathrm{O}$ and $\mathrm{CH}_{4}$ between the atmosphere and soils in spruce-fir forests in the northeastern United States. Biogeochemistry 18(3):119135

Chapin III, S., Zavaleta, E., Eviner, V., Rosamond, N., Vitousek, P. (2000). Consequences of changing biodiversity. Nature, 234-242.

Cheeke, T., Phillips, R., Brzostek, E., Rosling, A., Bever, J., Fransson, P. (2016). Dominant Mycorrhizal association of trees alter carbon and nutrient cycling by selecting for microbial groups with distinct enzymatic functions. New Phytologist, 432-442.

Dandie, C.E., Burton, D.L., Zebarth, B.J., Henderson, S.L., Trevors, J.T., Goyer, C. (2008). Changes in bacterial denitrifier community abundance over time in agricultural field and their relationship with denitrification activity. Applied and Environmental Microbiology, 5997 - 6005.

Davidson, E. A. (1993). Soil water content and the ratio of nitrous oxide to nitric oxide emitted from soil. Biogeochemistry of Global Change 369-386.

Davidson, E.A., \& Verchot, L.V. (2000). Testing the hole in the pipe model of nitric and nitrous oxide emissions from soils using the TRAGNET database. Global Biogeochemistry. 1035-1043.

DeForest, J., Smemo, K.A., Burke, D.J., Elliott, H.L., Becker,J.C. (2012). Soil microbial responses to elevated phosphorus and $\mathrm{pH}$ in acidic temperate deciduous forests. Biogeochemistry, 189-202. 
DeHayes, D., Schaberg, P., Hawley, G., Strimbeck, G. R. (1999). Acid Rain Impacts on Calcium Nutrition and Forest Health: Alteration of membrane-associated calcium leads to membrane destabilization and foliar injury in red spruce. Bioscience, $789-800$.

Driscoll, C., Lawrence, G., Bulger, A., Butler, T., Cronan, C., Eager, C., . . Weathers, K. (2001). Acid Deposition in the Northeastern United States: Sources and Inputs, Ecosystem Effects, and Management Strategies. Bioscience, 180-198.

Dodds, W.K., Bouska, W.W., Eitzmann, J.L., Pilger, T.J., Pitts, K.L., ...Thornburgh, D.J. (2009). Eutrophication of U.S. freshwaters: analysis of potential economic damages. Environmental Science \& Technology, 12-19.

Dukeunde, A., Schneider, D., Schmit, M., Veldkamp, E., Daniel, R. (2019). Tree species shape soil bacterial community structure and function in temperate deciduous forests. Frontiers in Microbiology, 15 -19.

Eickenscheidt N., Brumme R. (2013). Regulation of $\mathrm{N}_{2} \mathrm{O}$ and $\mathrm{NO}_{x}$ emission patterns in six acid temperate beech forest soils by soil gas diffusivity, $\mathrm{N}$ turnover, and atmospheric $\mathrm{NO}_{\mathrm{x}}$ concentrations. Plant Soil, 515529.

Eickenscheidt N., Brumme R., Veldkamp E. (2011). Direct contribution of nitrogen deposition to nitrous oxide emissions in a temperate beech and spruce forest-a ${ }^{15} \mathrm{~N}$ tracer study. Biogeosciences, 621-635.

Elias, P.E., Burger, J.A., Adams, M.B. (2009). Acid deposition effects on forest composition and growth on the Monongahela National Forest, West Virginia. Forest and Ecology Management, 2175-2182.

EPA. (2016). Basic Information about NO2. Retrieved from https://www.epa.gov/no2-pollution/basicinformation-about-no2

Estavillo, J., Merino, P., Pinot, M., Yamulki, S., Gebauer, G., Sapek, A., Corre, W. (2002). Short term effect of ploughing permanent pasture on $\mathrm{N} 2 \mathrm{O}$ production from nitrification and denitrification. Plant and Soil, 253-265.

Fenn, M., Poth, M., Aber, J., Baron, J., Bormann, B., Johnson, D., Lemly, D., Mcnulty, S., Ryan, D., Stottlemyer, R. (1998). Nitrogen Excess in North American Ecosystems: Predisposing Factors, Ecosystem Responses, and Management Strategies. Ecological Applications, 706-733.

Firestone, M., \& Davidson, E. (1989). Microbial basis of NO and N2O production and consumption in soils. Exchange of trace gases between terrestrial ecosystems and the atmosphere, 7-20.

Freedman, Z.B., Romanowicz, K.J., Upcurch, R.A., Zak, D.R. (2015). Differential responses of total and active soil microbial communities to long-term experimental N deposition. Soil Biology and Biochemistry, 275-282.

Frey, S.D., Ollinger, S., Nadelhoffer, K., Bowden. R., Brzostek, E., Burton, A., ... (2014). Chronic nitrogen additions suppress decomposition and sequester soil carbon in temperate forests. Biogeochemistry, 305316.

Frijlink, M., Abee, T., Laanbroek, H., de Boer, W., Konings, W. (1992). The bioenergetics of ammonia and hydroxylamine oxidation in Nitrosomonas europaea at acid and alkaline pH. Microbiology, 194-199. 
Gilliam, F. (2021). Response of Temperate Forest Ecosystems under Decreased Nitrogen Deposition: Research Challenges and Opportunities. Forests, 509.

Gilliam, F., Adams, M. B., Peterjohn, W. (2020). Response of soil fertility to 25 years of experimental acidification in a temperate hardwood forest. Journal of Environmental Quality, 1-12.

Gilliam, F. S., Welch, N. T., Phillips, A. H., Billmyer, J. H., Peterjohn, W. T., Fowler, Z. K., Walter, C. A., Burnham, M. B., May, J. D., Adams, M. B. (2016). Twenty-five-year response of the herbaceous layer of a temperate hardwood forest to elevated nitrogen deposition. Ecosphere, 01250.

Gilliam, F.S., Somerville, C., Lyttle, N., Adams, M.B. (2001). Factors influencing species variability in nitrogen processing in nitrogen saturated soils. The Scientific World. 505-513.

Gilliam, F.S., \& Turrill, N., (1993). Herbaceous layer and cover and biomass in young versus a mature stand of a central Appalachian hardwood forest. Bulletin of Torrey Botanical Club. 445-450.

Graham, E., Wieder, W., Leff, J., Weintraub, S., Townsend, A., Cleveland, C., . . . Nemergu, D. (2014). Short communication Do we need to understand microbial communities to predict ecosystem function? A comparison of statistical models of nitrogen cycling processes. Soil Biology and Biochemistry, 279-282.

Grennfelt, P., Engleryd, A., Forsius, M., Oysten, H: Rodhe, H., Cowling, E. (2020). Acid rain and air pollution: 50 years of progress in environmental science and policy. Ambio, 849-864.

Hallin, S., Jones, C., Schloter, M., Phillipot, L. (2009). Relationship between N-cycling communities and ecosystem functioning in a 50 year old fertilization experiment. International Society for Microbial Ecology, 567 - 605.

Hamid, A., \& Mahler, R. (1994). The Potential for Volatilization Losses of Applied Nitrogen Fertilizers From Northern Idaho Soils. Comm. Soil Sci. Plant Anal, 361-373.

Henry, S., Bru, D. Stres, B. Hallet, S. Phillipot, L. (2006). Quantitative Detection of the nosZ Gene, Encoding Nitrous Oxide Reductase, and Comparison of the Abundances of 16S rRNA, narG, nirK, and nosZ Genes in Soils. Applied and Environmental Microbiology. 5181-5189.

Hogberg, P., Johannisson, C., Yarwood, S., Ingeborg, C., Nasholm, T., Myrold, D., Hogberg, M. (2010). Recovery of ectomycorrhiza after 'nitrogen saturation' of a conifer forest. New Phytologist. 515-525.

Holmes, A., Costello, A., Lidstrom, M.E., Murrell J.C. (1995). Evidence that participate methane monooxygenase and ammonia monooxygenase may be evolutionarily related. FEMS Microbiology Letters, 203-208.

Hang-Wei H., Deli C., Ji-Zheng H. (2015). Microbial regulation of terrestrial nitrous oxide formation: understanding the biological pathways for prediction of emission rates, FEMS Microbiology Reviews, 39, 729-749.

Jensen, S., Holmes, A., Olsen, R., Murrell, J.C. (2000). Detection of Methane Oxidizing Bacteria in Forest Soil by Monooxygenase PCR Amplification. Microbial Ecology 282 -289. 
Jung, J., Yeom, J., Kim, J., Han, J., Soo Lim, H., Park, H., . . Park, W. (2011). Change in gene abundance in the nitrogen biogeochemical cyclewith temperature and nitrogen addition in Antarctic soils. Research in Microbiology, 1018-1026.

Kelly, C.N., Schoenholtz, S.H., Adams, M.B. (2010). Vegetation controls on carbon and nitrogen cycling and retention: contrasts in spruce and hardwood watershed budgets. Proceedings from the conference on the ecology and management of high-elevation forests in the central and southern Appalachian Mountains.

Kelly, C.N., Schwaner, G., Cummings, J., Driscoll, T. (2021). Metagenomic reconstruction of nitrogen and carbon cycling pathways in forest soil: Influence of different hardwood tree species. Soil Biology and Biochemistry 108226.

Kogelmann WJ \& Sharpe WE. (2006). Soil acidity and manganese in declining and nondeclining sugar maple stands in Pennsylvania. Journal of Environmental Quality, 433-41.

Kyriakou, V., Garagounis, I., Vourros, A., Vasileiou, E., Stoukides, M. (2020). An Electrochemical HaberBosch Process. Joule, 142-158.

Lawrence, G., Hazlett, P., Fernandez, I., Ouimet, R., Bailey, S., Shortle, W., . . Antidormi, M. (2015). Declining Acidic Deposition Begins Reversal of Forest-Soil Acidification in the Northeastern U.S. and Eastern Canada. Environmental Science and technology, 13103-13111.

Lehtovirta-Morley, L. (2018). Ammonia oxidation: Ecology, physiology, biochemistry and why they must all come together. FEMS microbiology letters.

Levy-Booth, D. J., Prescott, C. E., Grayston, S. J. (2014). Microbial functional genes involved in nitrogen fixation, nitrification and denitrification in forest ecosystems. Soil Biology and Biochemistry, 11-25.

Li M, Gao Y, Qian WJ, Shi L, Liu Y, Nelson WC, Nicora CD, Resch CT, Thompson C, Yan S, Fredrickson JK, Zachara JM, Liu C. (2017). Targeted quantification of functional enzyme dynamics in environmental samples for microbially mediated biogeochemical processes. Environ Microbiol Rep. 512-521

Liu, B., Frostegard, A., Bakken, L. (2014). Impaired reduction of N2O to N2 in acid soils is due to a posttranscriptional interference with the expression of nosZ. mBio. 1383- 14

Liu, D., Zhong, J., Zheng, X., Fan, C., Yu, J., Zhong, W. (2018). N2O Fluxes and Rates of Nitrification and Denitrification at the Sediment-Water Interface in Taihu Lake, China. Water, 1-14.

Lovett GM, Weathers KC, Arthur MA, Schultz JC. (2004). Nitrogen cycling in a northern hardwood forest: Do species matter? Biogeochemistry, 289-308.

Lovett, G.M., Goodale, C.L. (2011) A new conceptual model of nitrogen saturation based on experimental nitrogen addition to an oak forest. Ecosystems, 201-209

Lucas, R., Casper, B. (2007). Ectomycorrhizal community and extracellular enzyme activity following simulated atmospheric N deposition. Soil Biology and Biochemistry. 1162-1169.

Mathias, J., \& Thomas, R. (2018). Disentangling the effects of acidic air pollution, atmosphericCO2, and climate change on recent growth of red spruce trees in the Central Appalachian Mountains. Global Change Biology, 3938 - 3953. 
Melillo, J.M., Aber, J.D., Muratore, J.F. (1982). Nitrogen and lignin controls of hardwood leaf litter decomposition dynamics. Ecological Society of America, 621-626.

Michotey, V., Mejean, V., Bonin, P. (2000). Comparison of Method for Quantification of cytochrome cd1denitrifying bacteria in environmental marine samples. ASM Applied and Environmental Microbiology, 1563-1571.

Midgley, M., \& Sims, R.S. (2020). Mycorrhizal association better predicts tree effects on soil than leaf habit. Frontiers for Global Change, 1-14.

Midgley, M., \& Phillips, R. (2014). Mycorhizal association of dominant trees influence nitrate leaching responses to $\mathrm{N}$ deposition. Biogeochemistry, 241-253.

Moore, J., Anthony, M., Pec, G., Trocha, L., Trzebny, A., Geyer, K., .. Frey, S. (2020). Fungal community structure and function shifts with atmospheric nitrogen deposition. Global Change, 1-16.

Morales, S., Cosart, T., Holben, W. (2010). Bacterial gene abundances as indicators of greenhouse gas emission in soils. ISME J, 799-808.

Nadelhoffer, K. (2000). The potential effects of nitrogen deposition on fine-root production in forest ecosystems. New Phytologist, 131-139.

Nicol, G., Leininger, S., Schleper, C., Prosser, J. (2008). The influence of soil pH on the diversity, abundance and transcriptional activity of ammonia oxidizing archaea and bacteria. Environmental Microbiology, 2966- 2978.

Oikawa, P., Ge, C., J., W., Eberwein, R., Liang, L., Allsman, L., . . Jenerette, G. (2015). Unusually high soil nitrogen oxide emissions influence air quality in a high-temperature agricultural region. Nature Communications, 1-10.

Ollivier, J., ToweS., Bannert, A., Hai, B., Kastl, E.M., Meyer, A., Su, X.M., Kleineidam, K., Schloter, M. (2011). Nitrogen turnover in soil and global change. FEMS Microbiology, 3-16.

Ouyang, Y., Evans, S., Friesen, M., Tiemann, L. (2018). Effect of nitrogen fertilization on the abundance of nitrogen cycling genes in agricultural soils: A meta-analysis of field studies. Soil Biology and Biochemistry, 71-78.

Palmer, K., \& Horn, M. (2012). Actinobacterial nitrate reducers and proteobacterial denitrifiers are abundant in N2O metabolizing palsa peat. Applied and Environmental Microbiology, 5884 - 5596.

Peterjohn, W. T., Harlacher, M. A., Christ, M. J., \& Adams, M. B. 2015. "Testing associations between tree species and nitrate availability: Do consistent patterns exist across spatial scales?" Forest Ecology and Management, 335-343

Peterjohn, W.T., McGervey, R., Sexstone, A., Christ, M., Foster, C., Adams, M.B. (1998). Nitrous oxide production in two forested watersheds exhibiting symptoms of nitrogen saturation. Canadian Journal for Restoration 1723-1732.

Peterjohn, W.T., Adams, M. B., Gilliam, F. (1996). Symptoms of nitrogen saturation in two central Appalachian hardwood forest ecosystems. Biogeochemistry, 507-522. 
Petersen, D., Blazewicz, S., Firestone, M., Donald, H., Turetsky, M., Waldrop, M. (2012). Abundance of microbial genes associated with nitrogen cycling as indices of biogeochemical process rates across a vegetation gradient in Alaska. Environmental Biology, 993-1008.

Philippot, L., Andert, J., Jones, C., Bru, D., Hallin, S. (2011). Importance of Denitrifiers Lacking the Genes Encoding the Nitrous Oxide Reductase for N2O Emissions from Soil. Global Change Biology,1497-1504.

Philippot, L., Cuhel, J., Saby, N.P.A., Cheneby, D., Chronakova, A., Bru, D., ... Simek, M. (2009). Mapping field-scale spatial patterns of size and activity of the denitrifier community. Environmental Microbiology, 1518- 1526.

Philippot, L. (2002). Denitrifying genes in bacterial and Archaeal genomes. Biochimica et Biophysica Acta, $355-376$.

Phillips, R., Brzostek, E., Midgley, M. (2013). The mycorrhizal-associated nutrient economy: A new framework for predicting carbon-nutrient couplings in temperate forests. New Phytologist, 41-51.

Pilegaard, K. (2013). Processes regulating nitric oxide emissions from soils. Philosophical Transactions of the Royal Society B: Biological Sciences, 368.

Qin, H., Xing, X., Tang, Y. Zhu, B., Wei, X., Chen. X., Liu, Y. (2020). Soil moisture and activity of nitriteand nitrous oxide-reducing microbes enhanced nitrous oxide emissions in fallow paddy soils. Biol Fertil Soils. 53-67

Rocca, J. D., Hall, E. K., Lennon, J. T., Evans, S. E., Waldrop, M. P., Cotner, J. B., Wallenstein, M. D. (2015). Relationships between protein-encoding gene abundance and corresponding process are commonly assumed yet rarely observed. The ISME Journal, 1693-1699.

Reay, D., Davidson, E., Smith, K., Smith, P., Melillo, J., Dentener, F., Crutzen, P. (2012). Global agriculture and nitrous oxide emissions. Nature climate change, 410.

Richardson D, Felgate H, Watmough N, Thomson A, Baggs E. (2009). Mitigating release of the potent greenhouse gas $\mathrm{N}(2) \mathrm{O}$ from the nitrogen cycle - could enzymic regulation hold the key? Trends Biotechnology, 388-97.

Ribbons, R.R., Kepfer-Rojas, S., Kosawang, C. Hansen, O.K., Ambus, P., McDonald, M., ...Vesterdal, L. (2018) Context-dependent tree species effects on soil nitrogen transformations and related microbial functional genes. Biogeochemistry, 145-160.

Ribbons, R.R., Levy-Booth, D., Masse, J., Grayston, S., Mcdonald, M. V., Prescott, C. (2016). Linking microbial communities, functional genes and nitrogen cycling processes in forest floors under four tree species. Soil Biology and Biochemistry, 181-191.

Royo, A.A., Vicker, L.A., Long, R.P., Ristau, T.E., Stoleson, S.H., Stout, S.L. (2021). The forest of unintended consequences: anthropogenic actions triggers the rise and fall of black cherry. Bioscience, 683696.

Rotthauwe JH, Witzel KP, Liesack W. (1997). The ammonia monooxygenase structural gene amoA as a functional marker: molecular fine-scale analysis of natural ammonia- oxidizing populations. Appl Environ Microbiol 4704-12. 
Sanford, R.A., Wagner, D.D., Wu, Q., Chee-Sanford, J.C., Tho, S.H. (2012). Unexpected nondenitrifier nitrous oxide reductase gene diversity and abundance in soils. Proceedings of the National Academy of Sciences, 19709-19714.

Scala, D.J., Kerkhof, L.J. (1998). Nitrous oxide reductase (nosZ) gene-specific PCR primers for detection of denitrifiers and three nos $Z$ genes from marine sediments, FEMS Microbiology Letters, 61-68.

Schlesinger, W., \& Bernhardt, E. (2013). Biogeochemistry: an analysis of global change. San Diego, CA. Academic Press

Schwede, D., \& Lear, G. (2014). A novel hybrid approach for estimating total deposition in the United States. Atmospheric Environment, 207-220.

Shetty, R., \& Prakash, N. B. (2020). Effect of different biochars on acid soils and growth parameters of rice plants under aluminum toxicity. Nature Scientific Reports.

Singh, B., \& Sekhon, G. (1979). Nitrate pollution of ground water from farm use of nitrogen fertilizers. Agriculture and the environment, 207-255.

Smith, C., \& Osborn, M. (2009). Advantages and limitations of quantitative PCR (Q-PCR)-based approaches in microbial ecology. FEMS microbial ecology, 6-20.

Smith, V.H., Tilman, G.D., Nekola, J.C. (1999). Eutrophication: impacts of excess nutrient inputs on freshwater, marine, and terrestrial ecosystems. Environmental Pollution, 179-196.

Szukics, U., Hackl, E., Zechmeister-Boltenstern, S., Sessitsch, A. (2009). Contrasting response of two forest soils to nitrogen input: rapidly altered NO and N2O emissions and nirK abundance. Biol Fertil Soils, 855863.

Thoms, C., Gattinger, A., Jacob, M., Thomas, F., Glexiner, G. (2012). Direct and indirect effects of tree diversity drive soil microbial diversity in temperate deciduous forest. Soil Biology and Biochemistry, 15581565.

Throbäck IN, Enwall K, Jarvis A, Hallin S. (2004). Reassessing PCR primers targeting nirS, nirK and nosZ genes for community surveys of denitrifying bacteria with DGGE.FEMS Microbial Ecology.401-41.

Tresedar, K. (2008). Nitrogen additions and microbial biomass: a meta-analysis of ecosystem studies. Ecology Letters, 1111-1120.

Tresedar, K. (2004). A meta-analysis of mycorrhizal responses to nitrogen, phosphorus, and atmospheric CO2 in field studies. New Phytologist, 342-355.

Tsiknia, M., Paranychianakis, N., Varouchakis, E., Nikolaidis, N. (2015). Environmental Drivers of the distribution of nitrogen functional genes at a watershed scale. FEMS Microbial Ecology, 1-9.

USDA. (2014). Keys to Soil Taxonomy. NRCS, USDA.

USFS. (2020,March 4). About R\&D. Retrieved from U.S. Forest Service: https://www.fs.fed.us/research/about/ 
Venterea, R., Groffman, P., Castro, M., Verchot, L., Fernandez, I., Adams, M. B. (2004). Soil emissions of nitric oxide in two forest watersheds subjected to elevated N inputs. Forest Ecology and Management, 335349.

Verchot, L., Davidson, E., Cattânio, J. et al. (2000). Land-use change and biogeochemical controls of methane fluxes in soils of eastern Amazonia. Ecosystems, 41-56.

Vitousek, P., Aber, J., Howarth, R., Likens, G., Matson, P., S. D., . . Tilman, D. (1997). Human alteration of the global nitrogen cycle: sources and consequences. Ecological Applications, 737-750.

Wallenstein, M., McNulty, S., Fernandez, I., Boggs, J., Schlesinger, W. (2006). Nitrogen fertilization decreases forest soil fungal and bacterial biomass in three long-term experiments. Forest Ecology and Management, 459-468.

Wu, M., Zhang, J., Bao, Y., Liu, M., Jiang, C., Feng, Y., Li, Z. (2019). Long-term fertilization decreases chemical composition variation of soil humic substance across geographic distances in subtropical China. Soil and Tillage Research 105-111.

Xiao, Z., Rasmann, S., Yue, L., Lian, F., Zou, H., Wang, Z. (2019). The effect of biochar amendment on N-cycling genes in soils: A meta-analysis. Science of The Total Environment, 39-84.

Xu, R., Tian, H., Pan, S., Prior, S., Feng, Y., Batchelor, W. (2018). Global ammonia emissions from synthetic fertilizer applications in agricultural systems: Empirical and process-based estimates and uncertainty. Global Change Biology.

Yang, Y., Zhang, X., Zhang, C., Wang, H., Fu, X., Chen, F., . . Wang, J. (2018). Understory vegetation plays the key role in sustaining soil microbial biomass and extracellular enzyme activities. European Geosciences Union, 4481 - 4494.

Zhang T, Chen HYH, Ruan H. (2017). Global negative effects of nitrogen deposition on soil microbes. ISME J. 1817-1825 


\section{Supplemental Information}

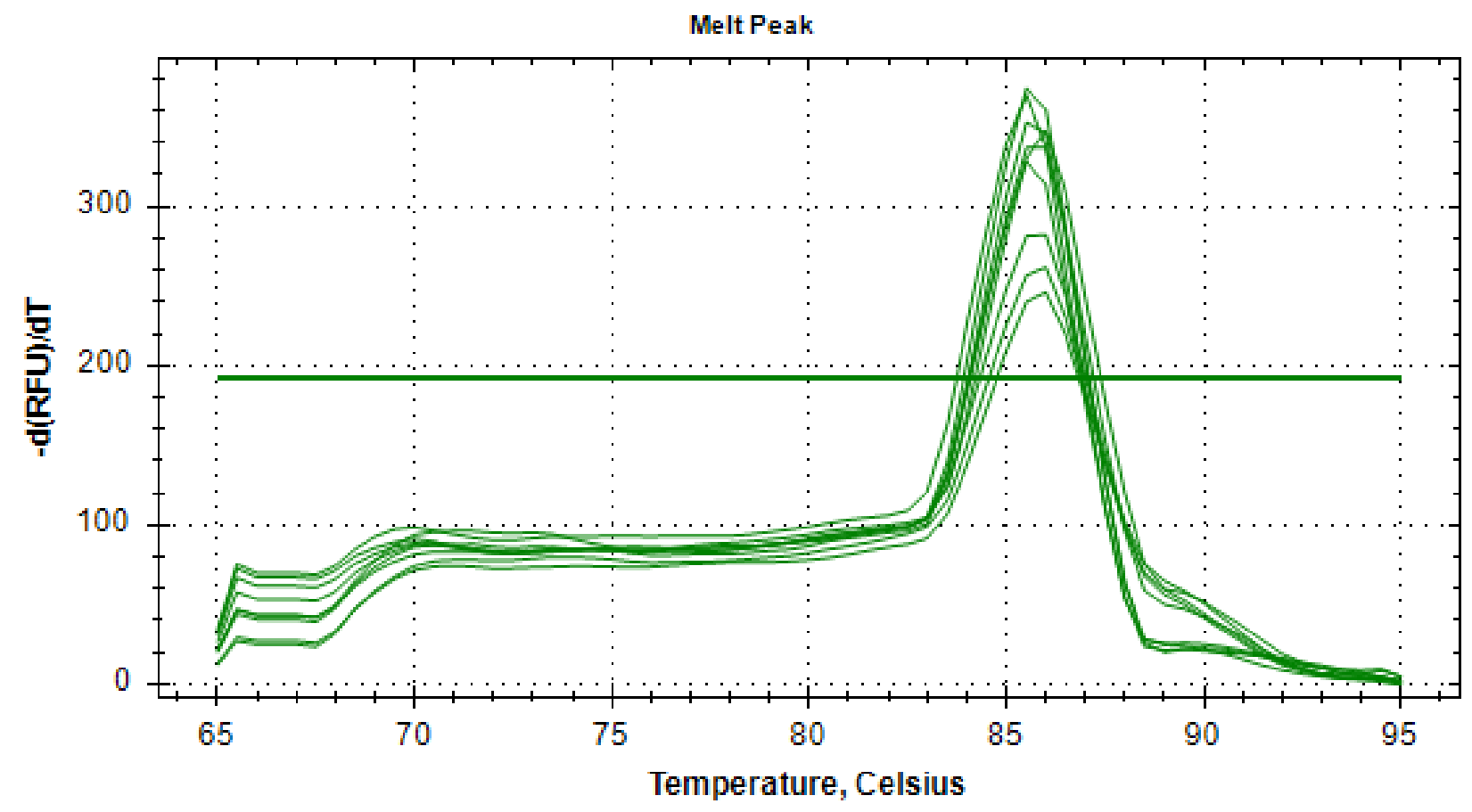

Figure S1. nosZ melt curve for standard curve creation using plasmid DNA from paracoccus denitrificans with primers nosZ2F and nosZ2R. 


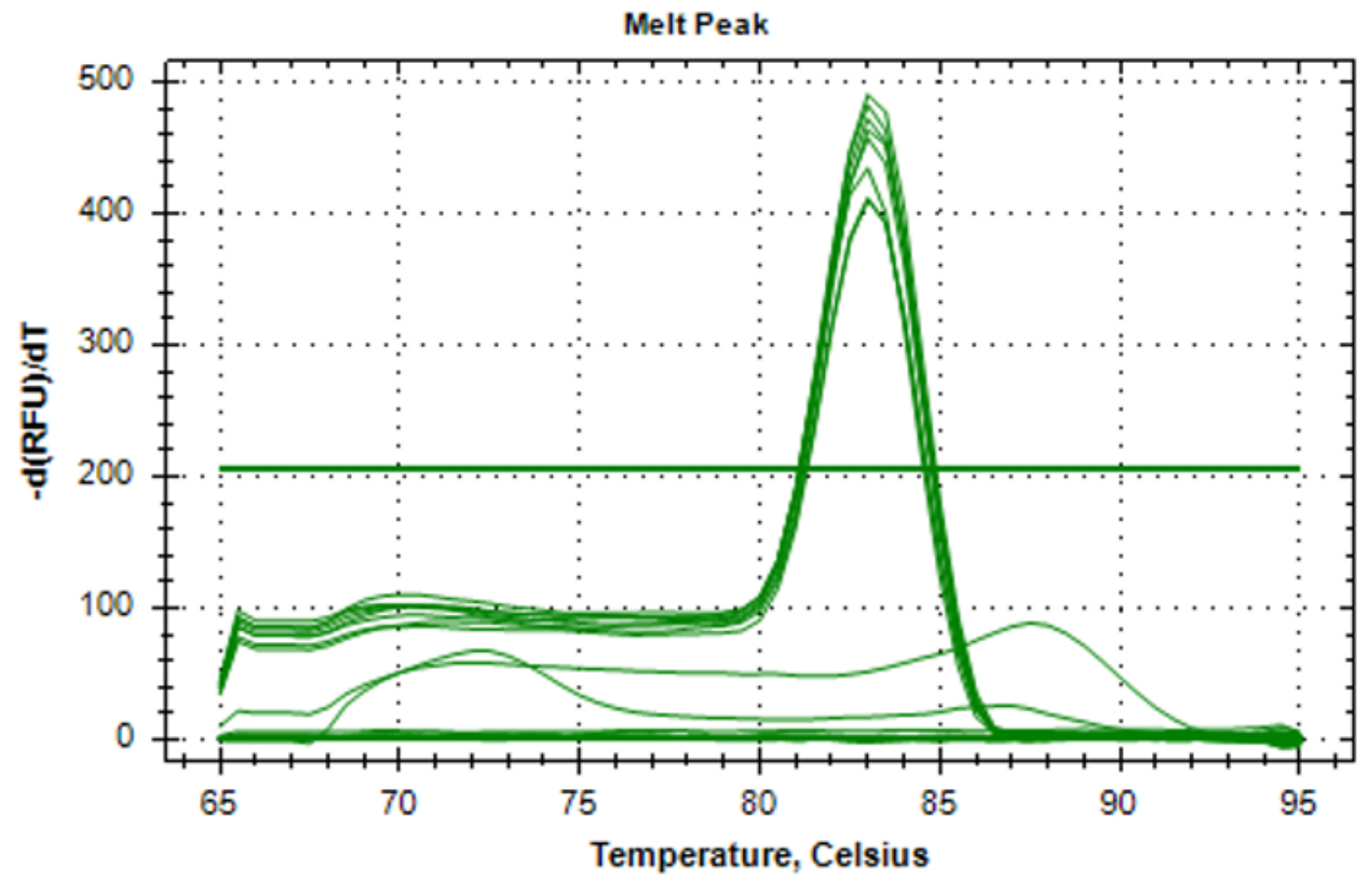

Figure S2. nirK melt curve for standard curve creation using plasmid DNA from Alcaligenes faecalis with primers nirK876 and nirK1040. 


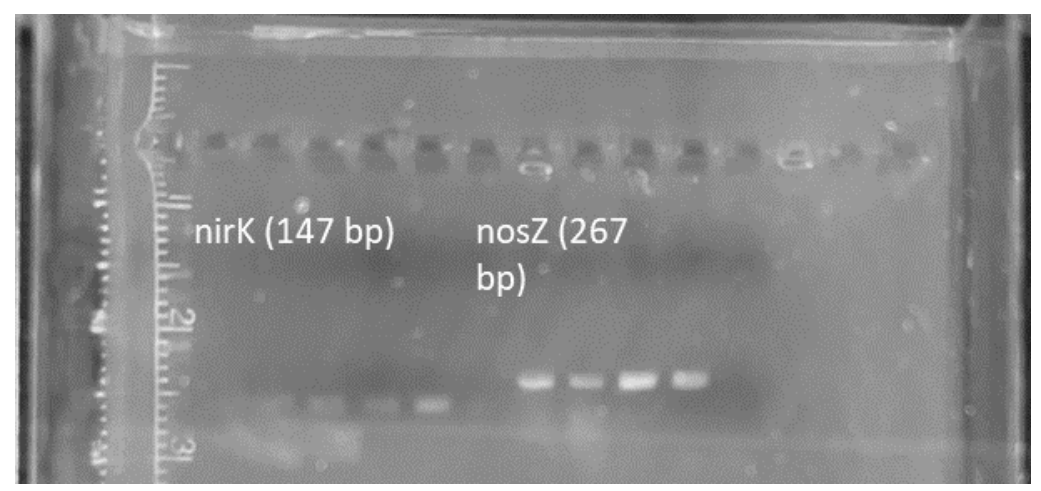

Figure S3. nirK 876 and 1040 and nosZ2F and nosZ2R primer set using standard PCR showing amplification at indicated $\mathrm{bp}$. 


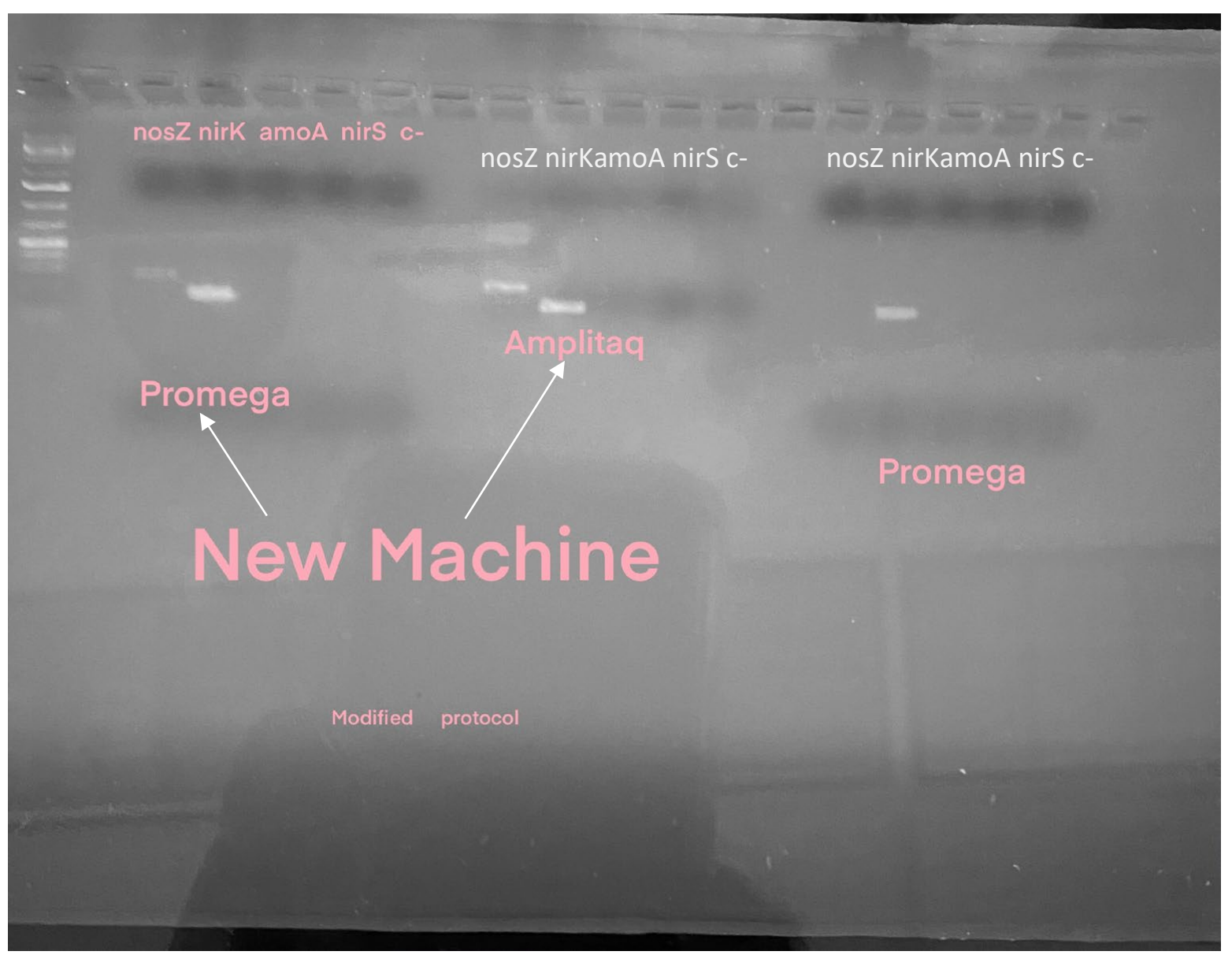

Figure S4. NosZ2F primer set, nirK876 primer set, amoA1F primer set, nirScd3af primer set run with Promega gotaq green mastermix and amplitaq gold mastermix on the Biorad thermocycler. 


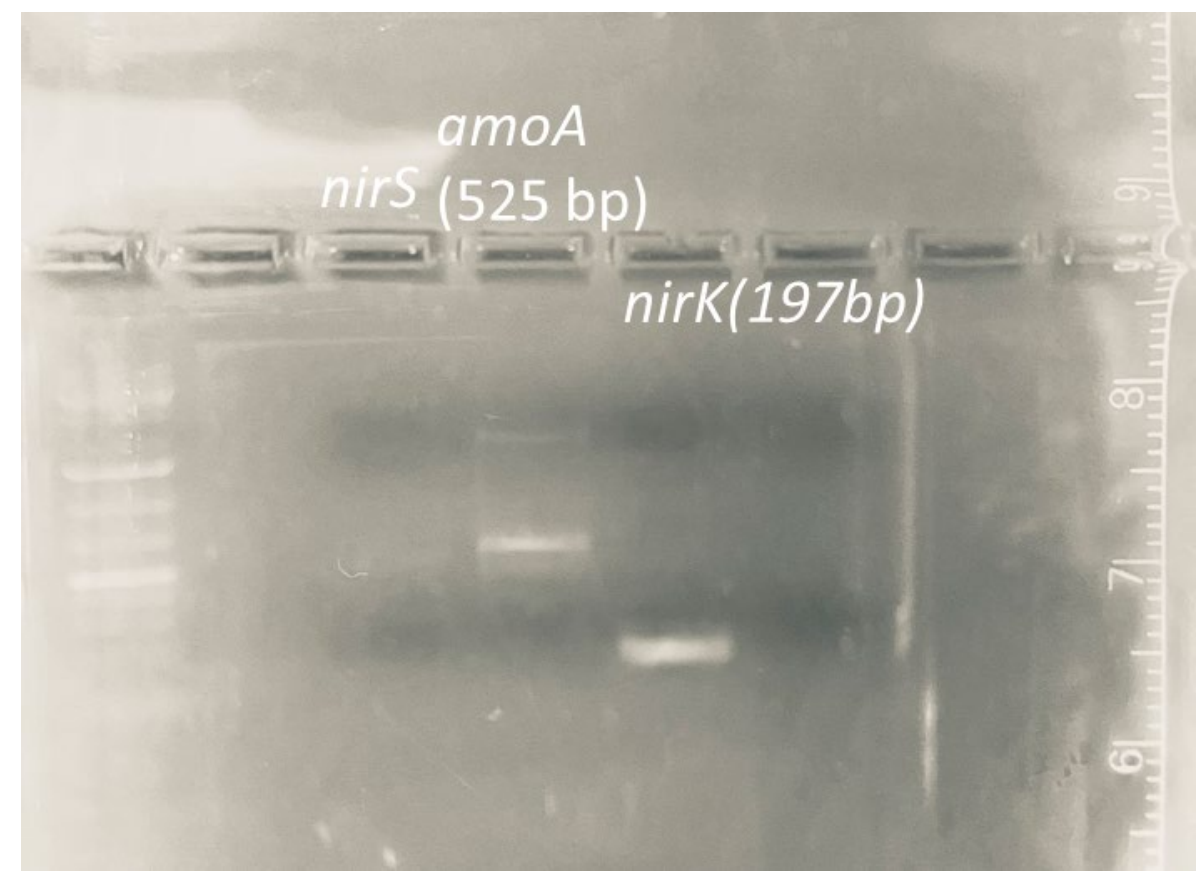

Figure S5. nirScd3af primer set and amoA189 and amoA682 primer set with nirK as the positive control. 


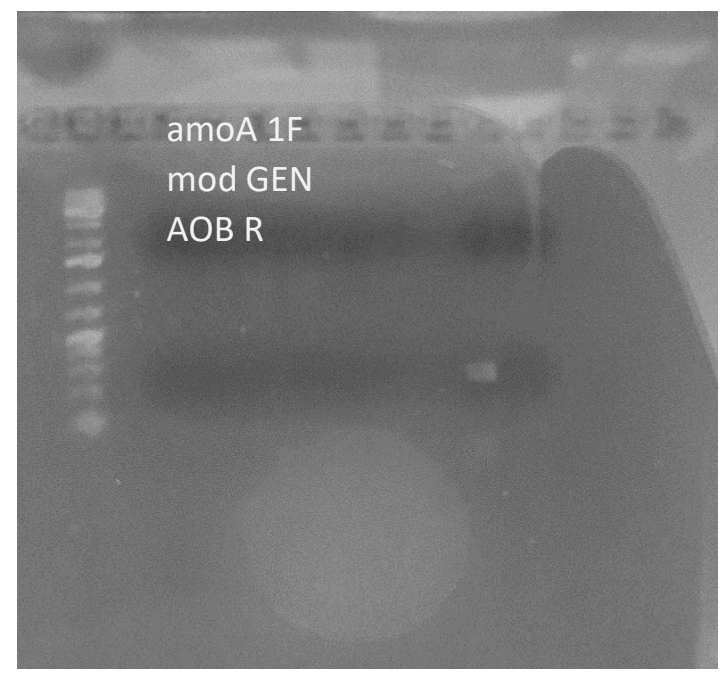

Figure S6. Touchdown PCR run with AmoA1F mod and GENAOB R primer set 


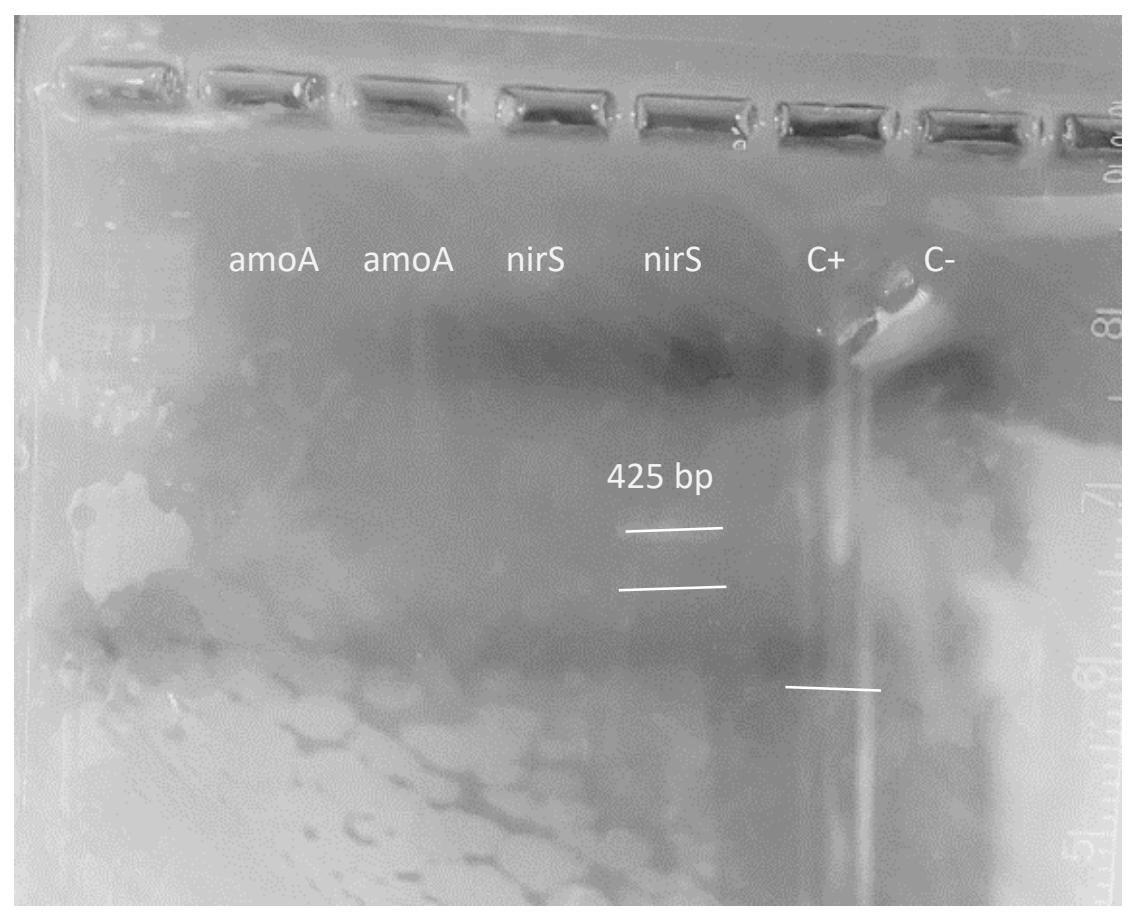

Figure S7. amoA1F mod and GEN AOB R primer set, nirScd3af and nisSR3cd primer set. 
nirS 4F 5R

C+ C-

(.)

Figure S8. Touchdown PCR run with nirS 4F 5R primer set 